\title{
norden
}

Recruitment and Retention of Health Care Professionals in the Nordic Countries

A Cross-national Analysis 

2 norden 



\title{
Recruitment and Retention of Health Care Professionals in the Nordic Countries
}

\author{
A Cross-national Analysis
}


Recruitment and Retention of Health Care Professionals in the Nordic Countries

A Cross-national Analysis

ISBN 978-92-893-3791-5 (PRIN)

ISBN 978-92-893-3793-9 (PDF)

ISBN 978-92-893-3792-2 (EPUB)

http://dx.doi.org/10.6027/TN2014-554

TemaNord 2014:554

ISSN 0908-6692

(C) Nordic Council of Ministers 2014

Layout: Hanne Lebech

Cover photo: Signelements

Copies: Rosendahls-Schultz Grafisk

Printed in Denmark

This publication has been published with financial support by the Nordic Council of Ministers. However, the contents of this publication do not necessarily reflect the views, policies or recommendations of the Nordic Council of Ministers.

www.norden.org/en/publications

\section{Nordic co-operation}

Nordic co-operation is one of the world's most extensive forms of regional collaboration, involving Denmark, Finland, Iceland, Norway, Sweden, and the Faroe Islands, Greenland, and Åland.

Nordic co-operation has firm traditions in politics, the economy, and culture. It plays an important role in European and international collaboration, and aims at creating a strong Nordic community in a strong Europe.

Nordic co-operation seeks to safeguard Nordic and regional interests and principles in the global community. Common Nordic values help the region solidify its position as one of the world's most innovative and competitive.

\section{Nordic Council of Ministers}

Ved Stranden 18

DK-1061 Copenhagen K

Phone (+45) 33960200

www.norden.org 


\section{Content}

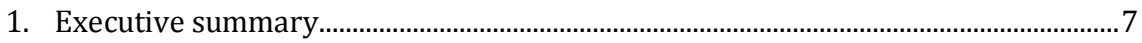

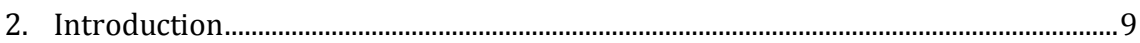

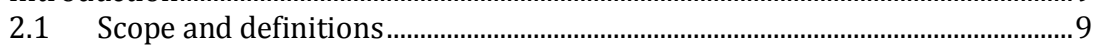

2.2 Methodology.................................................................................................. 10

3. The framework conditions of the Nordic health care sectors ....................................... 13

3.1 A common Nordic health care model ............................................................ 13

3.2 Judicial structure and organisation................................................................ 14

3.3 Financing the Nordic health care sectors......................................................... 17

3.4 Towards a new division of responsibilities ..................................................... 18

4. Challenges in the Nordic health care sectors................................................................ 21

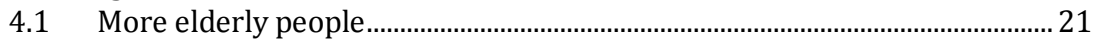

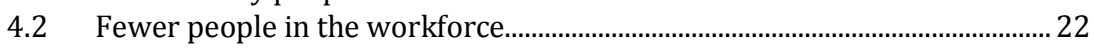

4.3 Fewer financial resources ............................................................................ 23

4.4 Higher level of efficiency and changed disease patterns................................. 23

4.5 A new home care paradigm ............................................................................ 25

4.6 Lack of health care personnel in the Nordic countries .................................. 26

5. Strategies for recruitment and retention in the Nordic health care sectors ........... 31

5.1 Recruitment and retention at two levels: the educational sector and the workplace ............................................................................................ 31

5.2 Recruitment and retention in the educational sector ..................................... 34

5.3 Recruitment and retention in the workplace .................................................. 38

5.4 Concluding remarks on strategies and initiatives .......................................... 42

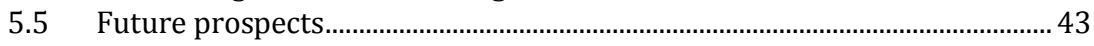

6. Lack of knowledge................................................................................................ 45

6.1 Do the reforms lead to more coherent health care sectors? ......................... 45

6.2 How can we accuretely predict the future need for personnel?.................... 46

6.3 What are the effects of different strategies and initiatives? .......................... 48

7. References................................................................................................................ 49

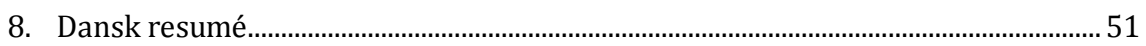

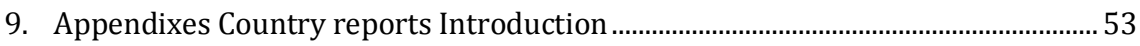

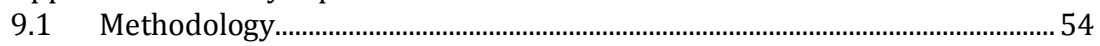

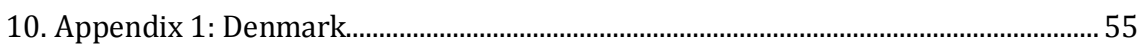

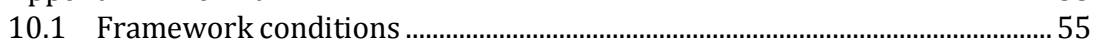

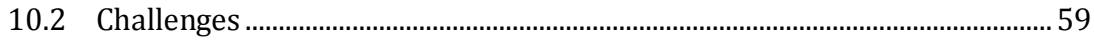

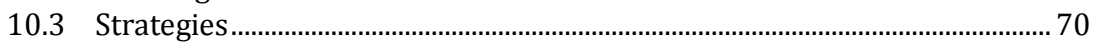

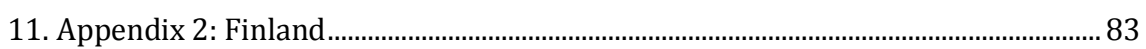

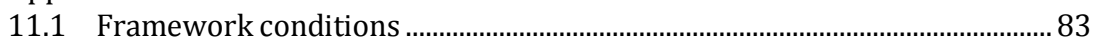

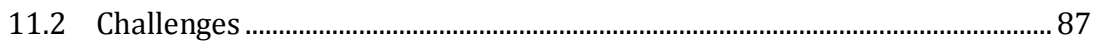

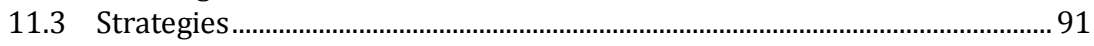




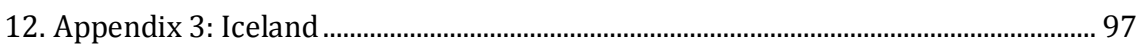

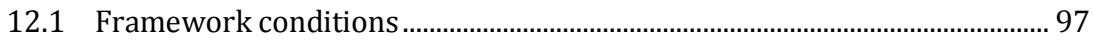

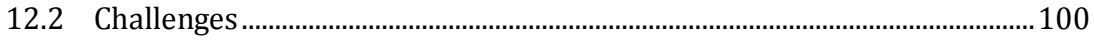

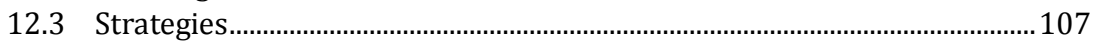

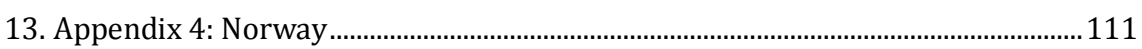

13.1 Framework conditions ..................................................................................111

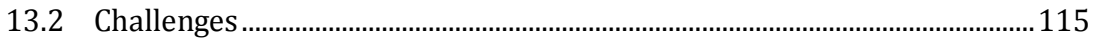

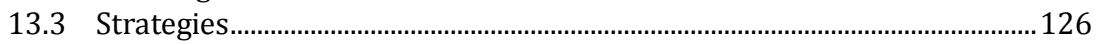

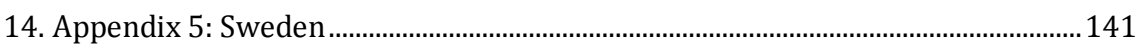

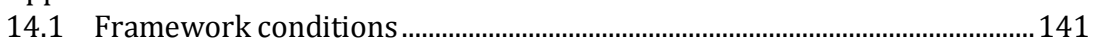

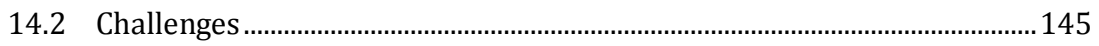

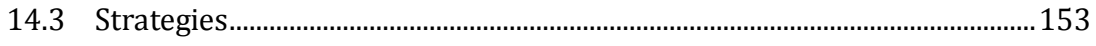




\section{Executive summary}

Like the rest of the EU, the Nordic states are facing challenges related to demographic change in the years to come as large groups of older workers are leaving the labour market while only small cohorts of young people are ready to take over. This is especially evident in the public sector, particularly in the municipalities, where the health and welfare services are anchored.

Increasing life expectancy and more elderly people with "new" diseases, as well as new inventions and technologies in the health care sector, result in increasing demand for health care services. With a declining workforce and limited financial means, the question is how to make best use of both the financial resources and the manpower in the Nordic health care sectors.

The Nordic countries are similar in many ways, for example in their heavy reliance on the public sector and the structure of the health care sector. One of the conclusions of this report is that the similarities provide a good starting point for common Nordic initiatives to recruit and retain staff in the health care sector.

Another conclusion is that the predictions point to varying shortages of staff in the coming years in the Nordic countries, and especially in certain geographical areas. However, the central political actors, i.e. governments and (professional) organisations, are especially preoccupied with the competency of the health care professionals. An important topic is thus how to ensure quality and coherence in the health care sectors. In addition, trends like welfare technology, increased efficiency, volunteering, etc. change the required competences among health care staff, and might even have the potential to substitute staff.

The analysis of various strategies in the Nordic countries and the concrete initiatives taken to mitigate the challenges related to the future health care sectors shows that the quantitative need (the number of health care professionals) is to some extent overshadowed by a qualitative perspective on the need for health care professionals (the competency of health care professionals and organisation of the health care sectors).

Denmark, Finland, Iceland, Norway, and Sweden face challenges associated with ensuring a coherent, high-quality health care sector. Interviews with professional organisations show that they are clear about 
their strategies and have launched various initiatives to meet the challenges. The analysis shows that the initiatives primarily focus on improving the quality of educational programmes and employee retention schemes. The latter initiative receives the most attention due to an explicit focus on continuing education for health care professionals, both at hospitals and in municipalities. The aim is to enhance service quality while focusing on professional and personal development of the staff.

The report also points to a lack of knowledge within some areas, such as the exact need for health care professionals, which by definition is difficult to calculate precisely. Other questions relate to the current restructuring of the health care sectors in the Nordic countries. There is a delay between initiation of reforms and their effects in terms of a changed division of responsibility, new tasks at different administrative levels, etc. Several organisational changes have taken place: the Coordination Reform in Norway, the local government reform in Denmark, the Health Service Act in Iceland and the introduction of the Health Care Act in Finland. It remains to be seen whether these reforms will be successful in maintaining the coherent and high-quality health care sectors that have been identified as a core vision by politicians in the five Nordic countries analysed in this report: Denmark, Finland, Iceland, Norway and Sweden.

Because there has been very few thorough and valid evaluations of the different initiatives, it is difficult to measure their effects. The effects of various recruitments campaigns, for instance, are difficult to estimate as we do not know how recruitment to educational programmes would have been if the campaigns had not been launched. In addition, we are yet to see the results of some of the newer initiatives, such as the policy on full-time work among health care professionals at hospitals that was launched in Denmark on 1st January 2014.

This report is part of the Sustainable Nordic Welfare programme launched by the Nordic Council of Ministers. 


\section{Introduction}

How can the Nordic model be further developed and revitalised? The Sustainable Nordic Welfare programme launched by the Nordic Council of Ministers seeks to find new and innovative welfare solutions in the Nordic Region. This means solutions that may contribute to increased quality and equality in education, work and health for the 25 million inhabitants of the Nordic region.

The demographic trends and financial constraints in the Nordic countries, and all over Europe, are posing challenges, especially in the health care sectors. The rising number of elderly with "new" diseases, as well as new technology and inventions, create a growing demand for health care services and health care personnel.

It is reasonable to expect the Nordic countries to share knowledge and learn from each other when it comes to meeting the challenges related to the shortage of health care professionals in the future. However, the aim of this report is to establish a clearer picture of the challenges in the future health care sectors in the five countries, and the strategies and initiatives implemented to mitigate them. The report thus paves the way for potential joint Nordic steps to prepare the Nordic health care sectors for the future in the best possible way.

\subsection{Scope and definitions}

This report builds on the results of five country reports written on the most populous Nordic countries; Denmark, Finland, Iceland, Norway and Sweden. The autonomous areas in Greenland, the Faroe Islands, and the Åland Islands are not represented. Traditionally, these areas find inspiration in the other Nordic countries (Denmark and Finland/Sweden, respectively). It should be mentioned that the level of attention given to the challenges associated with recruiting and retaining health care personnel by the authorities varies considerably among the Nordic countries. Norway expects to encounter the greatest challenges regarding lack of personnel in the future and seems to have the most comprehensive strategy for dealing with these challenges. This is reflected in the level of detail in the country report in the appendix. 
This cross-national report sums up the most important findings related to the following four main themes:

- Framework conditions of the health care sectors

- Future challenges within the Nordic health care sectors

- Strategies and initiatives to mitigate the challenges

- Lack of knowledge

The analysis in this report deals with the attending health sector (general practice and hospitals) and the care sector; i.e. services related to contact with citizens, health promotion, care of elderly, rehabilitation, etc. Our focus is thus on "warm hands" (e.g. doctors and physiotherapists) rather than "cold hands" (e.g. administrators and researchers) who have no or limited contact with citizens.

The health care sector is the point of departure of the analysis in this report, reflecting a vision of coherence across administrative levels in the Nordic countries. However, we draw an analytic distinction between the health sector, referring to activities related to citizens being treated at hospitals, and the care sector, referring to care and treatment of citizens after hospitalisation and/or due to old age

The field of analysis is the public health care sector, as opposed to the private health care sector. This choice reflects the fact that public health care services constitute the majority of the activities that take place in the health care sectors within the Nordic region.

Finally, the focus of the report is on the national level, i.e. national actors, central strategies and initiatives, and the overall framework conditions of the Nordic health care sectors. We assume that it is easiest to coordinate and target strategies from the central level. However, we acknowledged that many concrete initiatives start at the local level, and hence are not identified in this report.

\subsection{Methodology}

This report is based on desk research and interviews with 2-7 people in each of the five countries, amounting to 24 people in total. The interviews are semi-structured, which is beneficial because it allows for certain topics to be discussed in all five countries, while simultaneously giving interviewees an opportunity to highlight the most pressing con- 
cerns and predominant strategies from their perspectives. Table 2.1 lists the interview subjects.

In addition to interview data, the report makes use of national statistics in each of the five countries and Nordic Statistical Yearbook 2013 (Nordic Council of Ministers).

\begin{tabular}{|c|c|c|}
\hline Country & Organisation & Names \\
\hline \multicolumn{3}{|l|}{ Norway } \\
\hline & Employers' organization Spekter & Anne Turid Wikdahl \\
\hline & Norwegian Association of Local and Regional Authorities & $\begin{array}{l}\text { Liv Overaae, } \\
\text { Jorunn Leegaard } \\
\text { Hilde Lie Andersen }\end{array}$ \\
\hline & Norwegian Nurses Organisation & Solveig Bratseth \\
\hline & & Karen Bjøro \\
\hline & Norwegian Union of Municipal and General Employees & Raymond Turøy \\
\hline & The Norwegian Directorate of Health & Tonje Thorbjørnsen \\
\hline \multicolumn{3}{|l|}{ Denmark } \\
\hline & Ministry of Health and Prevention & Jakob Krogh \\
\hline & Danish Regions & Laura Toftegaard Pedersen \\
\hline & & Lotte Pedersen \\
\hline & & Thomas I. Jensen \\
\hline & Local Government Denmark & Mik Andreassen \\
\hline & & Karen Marie Myrndorff \\
\hline & FOA & Mie Andersen \\
\hline \multicolumn{3}{|l|}{ Sweden } \\
\hline & Ministry of Health and Social Affairs & Kent Lövgren \\
\hline & Ministry of Health and Social Affairs & Anna Gralberg \\
\hline \multicolumn{3}{|l|}{ Iceland } \\
\hline & Directorate of Health & Anna Björg Aradottir \\
\hline & Ministry of Welfare & Margret Bjork Svavarsdottir \\
\hline & & Kristjan Erlendsson \\
\hline & & Valgerdur Gunnarsdottir \\
\hline \multicolumn{3}{|l|}{ Finland } \\
\hline & Ministry of Social Affairs and Health & Marjukka Vallimies-Patomäki \\
\hline & & Antti Alila \\
\hline & National Institute for Health and Welfare & Reijo Ailasmaa \\
\hline
\end{tabular}





\section{The framework conditions of the Nordic health care sectors}

\subsection{A common Nordic health care model}

The aim of this chapter is to highlight similarities and differences within the Nordic health care sectors in relation to the sectors' structure, organisation, and financing. The chapter concludes that the Nordic health care sectors are comparable with many common features, and that it is therefore possible to talk about a Nordic health care model (Vrangbæk et al., 2009: 3).

The major European Observatory on Health Systems and Policies project (ibid.) confirms this observation. After the Second World War, the Nordic health care systems began evolving into a specific Nordic system, which diverges from other health care models in the world. Vital and unique features of these systems are free and equal access to health care of high quality, which is predominantly financed through taxes. In addition, the systems are politically controlled by decentralised administrative levels through democratic processes.

Another common feature of the Nordic health care systems is that the public sector is responsible for most of the financing as well as the provision of health care services. This makes it relatively easy to coordinate and plan activities in the Nordic health care sectors, such as strategies and visions regarding the future development of the sectors. However, it also makes the sectors vulnerable and poses specific challenges, which we will elaborate on in the next chapter.

Due to the similar framework conditions, joint Nordic projects, strategies, and initiatives to recruit and retain health care personnel should be possible. The fact that the local level is responsible for care of the elderly in four out of five countries makes it possible to take advantage of the opportunities provided by joint efforts. However, as we will see when examining the five national health care sectors closer, there are differences worth noting when common initiatives at the supranational level are contemplated.

As will be evident, other concerns than the numerical shortage of health care professionals are on the agenda in the Nordic countries, and 
these countries can benefit from sharing the experiences regarding these challenges.

\subsection{Judicial structure and organisation}

Table 3.1 summarises the organisational features of the Nordic health care sectors. National legislation and regulation define the responsibilities of each administrative level. The general pattern in the Nordic countries is a division into three administrative levels: the state, the regional and the local level. The next section describes these three levels.

\subsubsection{The state level}

The state level in each Nordic country has overall responsibility for the health care sector. However, as indicated in table 3.1, responsibility for the health care services demanded by citizens is generally placed at the lower administrative levels.

\section{Decentralised management}

In Denmark, Finland, Norway, and Sweden political responsibility goes hand in hand with responsibility for the different tasks related to health care services. A central feature of these four countries is the democratic processes in the health care sector, which gives elected representatives a say in relation to the management and priorities within the sector. This democratic control is anchored at both the regional and local levels. However, in practice, it takes place across the local, regional and state levels. As highlighted in the interviews, this indicates that coordination and cooperation between the different administrative levels in the countries are of utmost importance and a key feature of the health care sectors. This is especially true when it comes to handling the challenges related to demographic changes and changed disease patterns in the five countries, which will be examined in chapter 4 . health care sectors. This is especially true when it comes to handling the challenges related to demographic changes and changed disease patterns in the five countries, which will be examined in chapter 4 .

\section{Iceland - a central health care sector}

In Iceland, the state level is responsible for all health care services in the country, as shown in table 3.1. Decision-making, enforcement and management are concentrated at the central government level. The Icelandic health care system is thus the most centralised system in the Nordic 
region. The Health Care Act of 2007 introduced health care centres in local areas, but the purpose was not so much to decentralise as to increase cooperation within the country in order to mitigate the challenges posed by the size of the population. The Icelandic population is very small with 321,000 inhabitants, compared to roughly 5 million people in Norway, Finland and Denmark respectively, and 9.5 million people in Sweden. Almost 2/3 of the Icelandic population reside in the metropolitan area around Reykjavik. It is therefore not surprising that the health care sector has a centralized structure.

\subsubsection{The regional level - running the hospital}

As seen in table 3.1, in two of the five countries (Denmark and Sweden), the regional level is directly responsible for running hospitals. In Norway, four regional health authorities (helseforetak) hold a monopoly on health services. They are autonomous in terms of management and decisionmaking authority, but are owned by the state. The light blue colour in Table 3.1 depicts this variation in Norway, which differs from the other countries.

\begin{tabular}{|c|c|c|c|c|c|}
\hline & Denmark & Finland & Iceland & Norway & Sweden \\
\hline $\begin{array}{l}\text { State } \\
\text { level }\end{array}$ & $\begin{array}{l}\text { Overall } \\
\text { responsibility } \\
\text { for the health } \\
\text { care sector }\end{array}$ & $\begin{array}{l}\text { Overall respon- } \\
\text { sibility for the } \\
\text { health care } \\
\text { sector }\end{array}$ & $\begin{array}{l}\text { Overall re- } \\
\text { sponsibility for } \\
\text { the health care } \\
\text { sector } \\
\text { Hospitals } \\
\text { Care sector }\end{array}$ & $\begin{array}{l}\text { Overall responsi- } \\
\text { bility for the } \\
\text { health care sector } \\
\text { Hospitals }\end{array}$ & $\begin{array}{l}\text { Overall responsi- } \\
\text { bility for the } \\
\text { health care sector }\end{array}$ \\
\hline $\begin{array}{l}\text { Regio- } \\
\text { nal level }\end{array}$ & $\begin{array}{l}\text { Hospitals (five } \\
\text { regions) }\end{array}$ & $\begin{array}{l}\text { Joint municipal } \\
\text { corporations }\end{array}$ & $\begin{array}{l}7 \text { health } \\
\text { regions }\end{array}$ & $\begin{array}{l}\text { Four regional } \\
\text { health authorities }\end{array}$ & Hospitals (21 län) \\
\hline $\begin{array}{l}\text { Local } \\
\text { level }\end{array}$ & $\begin{array}{l}\text { Care sector } \\
\text { (98 municipa- } \\
\text { lities) }\end{array}$ & $\begin{array}{l}\text { Hospitals ( } 320 \\
\text { municipalities) } \\
\text { Care sector } \\
\text { ( } 320 \text { municipali- } \\
\text { ties) }\end{array}$ & $\begin{array}{l}15 \text { health } \\
\text { institutions }\end{array}$ & $\begin{array}{l}\text { Care sector } \\
\text { ( } 429 \text { municipaliti- } \\
\text { es) }\end{array}$ & $\begin{array}{l}\text { Care sector } \\
\text { ( } 290 \text { municipaliti- } \\
\text { es) }\end{array}$ \\
\hline
\end{tabular}

Note: The areas with italics depict geographical units, which are not politically and financially responsible for the services.

* Despite the English translation, the Norwegian helseregioner and helseforetak are not a regional authority as such. They are autonomous in terms of management and decision-making and are thus more than a geographical unit. The Norwegian state formally owns the hospitals, as shown in the table. 


\section{General practitioners (GPs)}

The five Nordic countries differ in terms of their organisation of general practitioners (GPs). In Denmark and Norway, GPs are private and independent (with collective agreements), organised through the regional and local levels, respectively. GPs serve as "gatekeepers" in the health care systems of Denmark and Norway, and they only refer citizens to specialist care when diagnosis and treatment cannot be managed by the GP. This function ensures treatment of patients at the "lowest level possible'. In Iceland, Sweden and Finland, GPs are organised within publicly run health centres. In Sweden, gatekeeping is voluntary, but as co-payments to specialists are higher than to the GP's, patients are encouraged to obtain a referral before seeing a specialist. In Iceland, citizens are free to approach specialists directly. They work on a fee-for-service basis negotiated by the medical associations and the central health authorities.

\subsubsection{The local level - running the care sector}

In Denmark, Norway, Sweden and Finland, the municipalities are responsible for the health and social care related to prevention work and care of the elderly and other people who need assistance. The responsibility for these groups is thus entirely located at the local level in the four countries. The local levels collect taxes to finance their activities, which leaves them substantial room for manoeuvre in terms of organisation and priorities within their portfolio of tasks. The main task of the regional level of relevance to this study is care of the elderly and treatment at home and in nursing homes.

A strong emphasis on prevention and communal health is also a common factor of the four countries. Responsibility for this is placed at the local level as well. Prevention work directed towards citizens focuses primarily on factors such as diet, exercise, smoking and alcohol (as opposed to prevention work targeted at patients). However, as discussed in the next chapter, the work related to preventing an illness from worsening is also part of the municipalities' portfolio of tasks.

Population-oriented disease prevention focuses on preventing an illness from worsening and limiting and/or delaying complications, i.e. secondary prevention and rehabilitation.

It differs from health promotion, which primarily addresses the healthy population and focuses on changing behaviour related to use of alcohol, tobacco, and physical exercise. 
As illustrated in table 3.1, the municipalities in Finland are also responsible for hospitals. However, the municipalities are organised as joint municipal corporations. This means that the entities responsible for the hospitals in Finland are large, which makes the practical operation of Finnish hospitals more similar to that of Denmark, Norway and Sweden than would appear from the table. However, political responsibility lies at the local level, which sets Finland apart from the other countries.

\subsection{Financing the Nordic health care sectors}

As the tables below indicate, the Nordic health care sectors are similar in terms of overall costs. Table 3.2 shows that public consumption of health care services constitutes the majority of health care services in the five Nordic countries. As is evident from table 3.5, the Nordic countries differ in regards to the kinds of services citizens must pay for themselves and the share of the population with private health insurance. In Denmark, for instance, nine out of ten have private health insurance through their job.

Table 3.2: Total health care expenditure in the Nordic countries. Euro per capita

\begin{tabular}{|c|c|c|c|}
\hline & Public consumption & Private consumption & Total costs \\
\hline Denmark & 2657 & 469 & 3126 \\
\hline Finland & 2231 & 775 & 2986 \\
\hline Iceland & 2227 & 543 & 2769 \\
\hline Norway & 5187 & 878 & 6065 \\
\hline Sweden & 2675 & 601 & 3286 \\
\hline
\end{tabular}

A very important similarity within the Nordic health care sectors is the fact that the systems are largely financed through taxation. Table 3.3 shows taxes' share of the overall costs of the health care systems in each of the Nordic countries. As can be seen, the countries are very similar in this respect even though Finland relies more on co-payments and out-ofpocket payments than the other Nordic countries. Furthermore, table 3.4 shows that the percentage of GDP spent on the public health care sector is very similar in the five countries.

Table 3.3: Taxes' share of costs in the health care sector

\begin{tabular}{ll} 
& Taxes' share of costs in the health care sector \\
Denmark & $85 \% .(2011)$ \\
Finland & $75 \% .(2012)$ \\
Iceland & $80 \% .(2012)$ \\
Norway & $85 \% .(2012)$ \\
Sweden & $82 \% .(2011)$ \\
\hline
\end{tabular}

Source: DAMVAD 2014, country reports and OECD stats. 
Table 3.4: \% of GDP spent in the public health care sector

\begin{tabular}{ll} 
& $\%$ of GDP spent in the public health care sector \\
Denmark & $9 \% .(2011)$ \\
Finland & $7 \% .(2012)$ \\
Iceland & $7 \% .(2012)$ \\
Norway & $8 \% .(2012)$ \\
Sweden & $8 \% .(2011)$ \\
\hline
\end{tabular}

Source: OECD stats.

To sum up, tables 3.2, 3.3, 3.4 and 3.5 reflect the five Nordic health care sectors, which have very similar overall financial structures.

\subsection{Towards a new division of responsibilities}

Major reforms that have changed the setup of the health care sectors have taken place in Iceland (described in section 3.2.1), Norway and Denmark in recent years. In addition, a local government reform is currently being prepared in Finland and will come into force in 2015. The Finish reform includes a change of the structure of health care services, focusing on creating larger entities to ensure that the population receives equitable high-quality services. Larger entities have been a focus in the reforms in Denmark and Norway as well. In Norway, hospital ownership was transferred to the central level in 2002. The central level has legal responsibility through four regional health authorities. The Coordination Reform (Samhandlingsreformen), which came into force in 2012, calls for stronger national control with the primary health sector as well. Even though Norwegian municipalities are formally entitled to collect taxes, they can only adjust the tax per cent in line with a nationally regulated ceiling. However, following the coordination reform, municipalities were given responsibility for new tasks, services and user groups. The trend towards centralisation, therefore, mainly has to do with financing of the health care sector.

The same picture is evident in Denmark, where the local government reform of 2007 changed the structure of tax collection from three to two levels (state and municipality). In the annual Financial Agreement, the central level possesses a high level of authority. However, the national level does not formally own the hospitals (as is the case in Norway). The power of the Danish Health and Medicines Authority, and the Ministry of Health's planning (and pressure) concerning the construction of new "super hospitals" are prominent examples of the way in which the Danish health care sector has become more centralised following the reform 
in 2007. However, the movement towards a larger portfolio of tasks within the municipalities is worth noting. Because of local selfgovernment, the municipalities have broad autonomy to organise health and social care as they wish, as long as they meet the minimum statutory requirements.

In terms of financing and organisation, Sweden remains less centralised than the other Nordic countries, as both counties and municipalities collect taxes and prioritise their financial means themselves. The Swedish Health and Medical Services Act is designed to give county councils and municipalities considerable freedom concerning their organisation of local health and medical services.

\begin{tabular}{|c|c|c|c|c|c|}
\hline & Denmark & Finland & Iceland & Norway & Sweden \\
\hline Taxation levels & $\begin{array}{l}\text { State and } \\
\text { municipality }\end{array}$ & $\begin{array}{l}\text { State and } \\
\text { municipality }\end{array}$ & State & $\begin{array}{l}\text { State, coun- } \\
\text { ties, munici- } \\
\text { pality }\end{array}$ & $\begin{array}{l}\text { State, coun- } \\
\text { ties, munici- } \\
\text { pality }\end{array}$ \\
\hline $\begin{array}{l}\text { Out-of-pocket } \\
\text { payments }\end{array}$ & $\begin{array}{l}\text { Dental care } \\
\text { (adults), } \\
\text { pharmaceuti- } \\
\text { cals, vaccina- } \\
\text { tions }\end{array}$ & $\begin{array}{l}\text { Primary care } \\
\text { visits (co- } \\
\text { payments), } \\
\text { pharmaceuti- } \\
\text { cals, dentists, } \\
\text { hospital } \\
\text { outpatient } \\
\text { treatment }\end{array}$ & $\begin{array}{l}\text { Primary care } \\
\text { visits (co- } \\
\text { payments), } \\
\text { hospital } \\
\text { outpatient } \\
\text { treatment, } \\
\text { diagnosis, } \\
\text { preventive } \\
\text { and screening } \\
\text { services, } \\
\text { immunization } \\
\text { and vaccina- } \\
\text { tion programs } \\
\text { and pharma- } \\
\text { ceuticals }\end{array}$ & $\begin{array}{l}\text { RGPs, special- } \\
\text { ist visits / } \\
\text { outpatient } \\
\text { hospital care, } \\
\text { same-day } \\
\text { surgery, } \\
\text { physiothera- } \\
\text { py, prescrip- } \\
\text { tion drugs, } \\
\text { radiology, } \\
\text { laboratory } \\
\text { tests, dental } \\
\text { care (adults) }\end{array}$ & $\begin{array}{l}\text { Primary care } \\
\text { visits (co- } \\
\text { payments), } \\
\text { dental care } \\
\text { (adults), } \\
\text { outpatient } \\
\text { prescription } \\
\text { drugs, special- } \\
\text { ist care (co- } \\
\text { payments) }\end{array}$ \\
\hline $\begin{array}{l}\text { Share of popula- } \\
\text { tion with private } \\
\text { health insurance }\end{array}$ & $\begin{array}{l}\text { Approximate- } \\
\text { ly } 15 \% .\end{array}$ & $\begin{array}{l}\text { Approximate- } \\
\text { ly } 2 \% .\end{array}$ & $\begin{array}{l}\text { Approximate- } \\
\text { ly } 0 \% \text {. }\end{array}$ & $\begin{array}{l}\text { Approximate- } \\
\text { ly } 5 \% .\end{array}$ & $\begin{array}{l}\text { Approximate- } \\
\text { ly } 5 \% \text {. }\end{array}$ \\
\hline
\end{tabular}

Source: DAMVAD 2014, country reports. 



\section{Challenges in the Nordic health care sectors}

This chapter focuses on the future challenges for the health care sectors in the Nordic countries that affect the demand for health care professionals. In short, the Nordic health care sectors will need to solve more tasks with fewer financial and human resources. The following trends are identifiable in the Nordic countries and addressed in this chapter:

- More elderly people

- Fewer people in the workforce

- Fewer financial resources

- Higher level of efficiency and changed disease patterns

- A new home care paradigm

\subsection{More elderly people}

There are profound demographic challenges within each of the five Nordic countries. As table 4.1 shows, the Nordic countries are quite similar in terms of current and future demographic composition.

Table 4.1: Number of people above the age of 70, percentages

\begin{tabular}{lrr} 
& $\mathbf{2 0 1 3}$ & $\mathbf{2 0 3 0}$ \\
Denmark & 12 & 17 \\
Finland & 13 & 20 \\
Iceland & 9 & 14 \\
Norway & $11^{*}$ & 14 \\
Sweden & 13 & 16 \\
\hline
\end{tabular}

Source: DAMVAD 2014, country reports.

Note: * Prediction, 2015.

In the Nordic countries on average, $28.5 \%$. of the total population is above the age of 65 . The number is almost the same in EU27 (28.4\%.). After 2030, the EU27 countries are expected to experience a steeper increase in the number of elderly than the Nordic countries. As such, by 
2040 , the proportion of the population above 65 is projected reach $45 \%$. in the Nordic countries and 50\%. in the EU27. ${ }^{1}$

The aging population poses an obvious challenge to the Nordic health care sectors, as the number of elderly people in need of care is rising. In addition, life expectancy is relatively high in all of the Nordic countries, as shown in the table below.

\begin{tabular}{lrr} 
Table 4.2: Life expectancy in the Nordic countries. Age & & Men \\
& Women & 77.9 \\
Denmark & 81.9 & 77.5 \\
Finland & 83.4 & 80.9 \\
Iceland & 83.9 & 79.4 \\
Norway & 83.4 & 79.9 \\
Sweden & 83.5 & \\
\hline
\end{tabular}

Source: National Statistical Institutes (Nordic Statistical Yearbook 2013).

There is thus an increasing need for personnel in the health care sector that can care for a larger number of elderly who live longer lives and whose needs change accordingly.

\subsection{Fewer people in the workforce}

In spite of general population growth in the five Nordic countries, ${ }^{2}$ the demographic challenges are boosted by the fact that the highest growth is expected to occur among people aged 67-79 due to large cohorts born after the Second World War. In Norway, for example, this group is expected to double from 2010-2050. This means that fewer people will have to take care of more people in the years to come, a phenomenon known as "the burden of the elderly." In Denmark, the number of people out of the workforce exceeds the number of people in the workforce (aged 18-64 today). It is predicted that the gap will increase the next 20 years, then start decreasing again, and only slowly stabilize near 2050. The picture is similar in the other Nordic countries. To make matters worse, many of the people who are about to leave the labour markets in the Nordic countries are employed in the public sector. The challenges associated with a declin-

${ }^{1}$ Nordic Statistical Yearbook 2013.

2 Nordic Statistical Yearbook 2013. 
ing workforce are thus especially great at the regional and local levels, where the provision of welfare and health services is anchored.

On the other hand, it is widely argued that the "new elderly" are not as dependent on younger generations as generations of elderly in the past. A large group of "seniors" (60+) have ample financial means, live healthy, active lives, and thus do not require the same amount of care as previous generations. This development is expected to reduce the pressure on the health care sectors to some degree.

\subsection{Fewer financial resources}

An important and central characteristic of the Nordic health care systems is that they are financed through taxes, as opposed to private means, as described in the previous chapter. The decreasing number of people in the workforces, combined with the constant and fast development of new treatments and medications, therefore puts substantial pressure on the Nordic health care systems. The Nordic welfare states are encountering financial pressure regarding financing of the welfare state in general and the health care sectors specifically. Another point of pressure comes from the financial crisis, which has affected the economies of the Nordic countries to various degrees. The Nordic health care systems are very fragile, and even if there was no shortage of manpower in the Nordic countries, endless hiring simply would not be an option because of limited financial means. ${ }^{3}$

\subsection{Higher level of efficiency and changed disease patterns}

As explained in detail in chapter 3, the typical division of labour is regional responsibility for hospital operation and treatment and local responsibility for care of the elderly and other people in need of care. Due to financial pressures and changes in treatment methods following an enormous focus on specialisation and efficiency, the general trend in the Nordic countries is that the number of days a patient stays at a hospital

\footnotetext{
${ }^{3}$ An exception to this overall picture is Norway, as the country is more financially secure than the rest of the countries in the Nordic region. However, the shortage of human resources is particularly profound here.
} 
after treatment/surgery is declining. This pattern exists within all patient groups and poses serious challenges in terms of cooperation across the institutional boundaries between the health sectors and the care sectors. The rising number of elderly with increased life expectancy adds an additional dimension to this challenge due to the typical characteristics of "the elderly medical patient" highlighted in the box below.

The elderly medical patient poses a challenge to the Nordic health care systems. $\mathrm{He} / \mathrm{she}$ is characterised by the following factors:

- Co-morbidity (more diseases simultaneously)

- Physical and/or cognitive disabilities

- Limited ability to take care of him/herself

- Polypharmacy

- Need for care and/or hospitalisation(s).

The fact that people are discharged from hospital earlier means that there is a risk of re-hospitalisation if they are not treated correctly when they return home or to a nursing home. In the words of a Danish interviewee, there is a shift from "the elderly being citizens in their own homes to being patients in their own homes." 4 The same trend is evident among younger cohorts, where a growing number of chronically-ill patients are identified across the Nordic countries. Some of the diseases are related to changed lifestyles.

Typical chronic diseases in the Nordic countries:

- Asthma

- Mental disorders

- Diabetes

- Cardiovascular disease

- Lung disease

- Rheumatoid arthritis.

${ }^{4}$ Karen Marie Myrndorff, Local Government Denmark. 
Due to financial pressures and medical expertise, specialisation and efficiency at hospitals, and changed disease patterns, the competences required among health care staff is changing. Health care workers and therapists ${ }^{5}$ working in the care sector face new challenges and tasks because they meet weaker citizens in their homes.

Health care workers, terminology:

- Social- og sundhedshjælpere (DK)

- Social- og sundhedsassistenter (authorised to hand out medication) (DK)

- Närvårdare (FI),

- Sjúkralidar (IC)

- Undersköterske (S)

- Helsefagsarbeider (N).

There is an evident mismatch between the supply of and demand for competences within certain groups of health care professionals in Denmark, Sweden and Norway. Recruitment of competent labour therefore receives much attention in the Nordic health care sectors and to some extent overshadows the quantitative need for health personnel

\subsection{A new home care paradigm}

Another qualitative change in the Nordic countries is everyday rehabilitation, which is a high priority in the four largest Nordic countries in particular. It is believed that "help to self-help" and "everyday rehabilitation" are ways to mitigate the demographic and financial challenges facing the Nordic countries. Everyday rehabilitation entails that instead of focusing on solving the immediate needs of the elderly, such as house cleaning and personal hygiene, the health care worker looks at the underlying health issues that make the elderly unable to take care of themselves. The implication is an increased focus on preventive and rehabilitation measures to ensure that as many elderly people as possible can lead long and healthy lives with little dependency on help from health care workers. An important argument in the debate on everyday rehabil-

5 Umbrella term for physiotherapist, ergotherapist etc. 
itation is that this new approach may even improve the quality of life for some elderly because they become less dependent on help and assistance and remain in charge of their own lives. The idea of everyday rehabilitation was originally introduced in Sweden around the turn of the millennium. It spread to Denmark in the following decade, and Norway and Finland have initiated similar policies in recent years. ${ }^{6}$ In Iceland, initiatives regarding everyday rehabilitation have been taken as well. In Iceland, there is also a great focus on maintaining the elderly in their own homes instead of moving them to nursing homes.

The trend described also leads to a change in the competences needed among people who care for the large numbers of elderly in the Nordic countries. Health care professionals must be able to teach the elderly/ the younger chronic patients how to perform their own daily care instead of doing it for them. This increases the need for interdisciplinary skills in the health care sectors, especially among health workers and therapists employed in the municipalities. This adds to the fact that recruiting health care professionals is not only about achieving a certain number, but also about the quality of students and employees in the Nordic health care sectors.

\subsection{Lack of health care personnel in the Nordic countries}

In the Nordic countries, the financial crisis of 2008 and the subsequent recession changed the predictions relating to the demand for health care professionals in the future. Newer predictions show a general shortage of health care professionals in the future, but it is generally lower than what was expected in the early 2000s. This reminds us that it is important to remember that predictions are based on a range of uncertain variables. Thus, even though models are becoming increasingly advanced, it is not possible to know with certainty whether the right estimates have been made.

6http://www.regjeringen.no/nb/dep/hod/dok/regpubl/stmeld/2012-2013/meld-st-29-20122013/ 6/3.html?id=723351, http://www.rcc.gov.pt/SiteCollectionDocuments/

NationalFrameworkforHighQualityServicesforOlder\%20.pdf 
The Ministry of Finance in Denmark points to the following characteristics when it explains the factors that are likely to impact predictions related to the future need for certain professions:

- Students' choice of education and the dimensioning of education with more applicants than places

- Completion times and rates in the educational system

- Changed patterns of entry into professions, from people outside the country in question and/or from the private sector

- Retention among older employees

- Changed division of labour among the professions

- Changed legislation

Source: Danish Ministry of Finance (2009)

In Norway, the predictions foresee a shortage of health care professionals. Of the Nordic countries, the shortage seems to be most pronounced here, albeit manageable at this stage. Especially the group of vocationally trained health care workers is expected to see a shortfall. In 2020, a shortage of 10-18.000 is expected, and in 2030, a shortage of 35-52.000 is expected within this group. The ranges of the predictions points to the fact that predictions are always associated with a degree of uncertainty. However, the message remains clear.

A shortage of nurses is also predicted in Norway. 43.000 nurses will leave their job before 2022. To meet the resulting demand, it will be necessary to employ approximately 50.000 nurses. Unskilled workers currently account for about one-third of the man-labour years in the municipal care sector in Norway. To add to this picture, health care professionals from the other Nordic countries come to Norway to work. The Norwegian authorities have decided not to recruit actively in the other Nordic countries, as the other Nordic countries have a lack of health care professionals. However, due to low unemployment and high wages, Norway is now a very popular destination for Nordic health care professionals, and today $11 \%$. of the foreigners employed in Norway work in the health care sector. Especially Icelandic health care professionals (mainly doctors and nurses) work in Norway for periods of their lives. 
The problems arising from emigration/commuting of health care professionals from Iceland is the main concern regarding the country's future needs. ${ }^{7}$ In 2006, the Faculty of Economics of the University of Iceland submitted a report to the Ministry of Health. It predicted the long-term needs of four key professions (doctors, nurses, associate nurses and physiotherapists). The Ministry of Welfare reviewed the 2006 report in 2012 and made similar findings.

In Sweden, the need for staffing is predicted to increase as well. Within care of the elderly, staffing needs will rise by three times as much as the health sector. Thus staffing requirements in the care sector will increase by $67-\%$, depending on different scenarios. About 400,000 people are employed in the Swedish health care sector in 2014. 160,000 of these people work in the care sector. According to Statistics Sweden, the country is facing a growing surplus of highly educated workers, especially in the humanities, the arts, and natural sciences, and a deficit of people with upper secondary school qualifications, not least in health and social care. Another specific concern in Sweden is the geographical differences in terms of age composition and the need for health care professionals. At the national level, the proportion of people aged 65 or above is expected to rise to $24 \%$. by 2040 . In metropolitan areas, the share is expected to rise to $19 \%$, which corresponds to the present national average. At the same time, the proportion in sparsely populated municipalities is expected to rise to $32 \%$. In other words, almost one in three will be aged 65 or above in these areas around $2040 .{ }^{8}$ The lack of health care professionals is thus expected to be more prominent in certain geographical areas than others.

In Denmark, the future need for health care professionals is apparently not as pronounced as in the other Nordic countries, but a shortage of nurses and health care workers is expected. Some predictions show a need for doctors with certain medical qualifications. However, as in the other Nordic countries, it is very important to consider geography when describing the future need for health care professionals in Denmark. While the capital region does not foresee a need, the need for nurses and health care workers is particularly evident in geographically remote areas, such as the North Denmark Region, and the southern part of Zealand. Many young people leave the remote areas to attend university / Universi-

\footnotetext{
7 Interview with an employee at the Icelandic Ministry of Welfare.

${ }^{8} \mathrm{http}: / /$ www.regeringen.se/content/1/c6/22/16/72/b5e860d7.pdf
} 
ty College in the larger cities. At the same time, most old people live in the sparsely populated areas outside the cities. These geographical differences are a general trend in the Nordic countries, and point to the fact that locally initiated programmes can be an important tool in mitigating the challenges related to the need for health care professionals.

In Finland, the current long-term forecasts regarding demand for labour cover the period 2008-2025. The general workforce planning process covers 28 industries, including health care. The workforce demand projections of the Government Institute for Economic Research comprise three different scenarios. According to the target scenario, on average about every fifth new job in the next 15 years will be created in health and social work. This means that there will be around 235,450 job vacancies in health and social work in the period 2008-2025. One scenario predicts that the number of employees in the health care sector will rise by $57 \%$. to meet the demand. In the newest report from 2014, it is predicted that in 2030 there will be 450.000 social and health care workers in the field. From 2012 to 2030, the number of employed will grow by about 77.000 people, of which approximately $65 \%$. will be working in the public sector (if the development in the production structure of the industry remains unchanged) .

${ }^{9}$ http://www.vatt.fi/file/vatt_publication_pdf/t176.pdf 



\section{Strategies for recruitment and retention in the Nordic health care sectors}

The Nordic countries face challenges concerning the future of the health care sectors. The trends point towards more and "new" elderly people with other types of disease, leading to an increased demand for welfare services, combined with fewer people in the workforce. These trends will unfold in a Nordic region slowly recovering from the worldwide financial crisis. The countries and their citizens are getting used to a future with fewer opportunities for increased public spending. Hospitals are improving their efficiency, and patients who are discharged from hospital need a different kind of care, which focuses on treatment as well as traditional care. At the same time, the Nordic countries are experiencing a changed paradigm regarding home care in whicheveryday rehabilitation and "help to self-help" are high priorities.

These trends clearly influence the future need for health care professionals, and thus the strategies and initiatives launched by the central actors in each of the Nordic countries. These strategies and initiatives are the topic of this chapter.

\subsection{Recruitment and retention at two levels: the educational sector and the workplace}

In general, the challenges of recruitment and retention of personnel in the health sector can be addressed at two levels: the educational level and the workplace level.

Recruitment and retention at the educational level relates to recruitment and retention of students in educational programmes aimed at the health care sectors. Both young people who are ready to start vocational or tertiary education and older people who are unskilled or educated within other industries are thus potential future health care professionals.

The workplace level relates to recruitment and retention of personnel at different workplaces that provide health and/or social care, such as 
hospitals, nursing homes or enterprises that provide care for the elderly, primarily in the municipalities. This means that many initiatives are launched at the local level, for example at a hospital or in a municipality. However, more central initiatives are also taken to address the challenges at the workplace level. One example is the import of doctors from countries far from the Nordic region. In relation to retention at the workplace level, the focus is on building good workplaces, good management, and improving opportunities for career development.

\subsubsection{Differences in strategic focus}

It is evident from the analysis of the countries' strategies and concrete initiatives that there are different ways of dealing with the challenges described above. The level of coordination between the authorities in the different countries varies. The efforts in Norway seems to be the most comprehensive and is coordinated from the central level by the relevant ministries, which is unique for the Nordic region. This reflects the fact that Norway expects to encounter the most severe shortage of health care staff in the years to come, as discussed in chapter 5.

In Finland, the work is also coordinated through a comprehensive strategy. However, the focus is not as explicitly on the lack of staff in the future as in Norway. Rather, it addresses several aspects related to the development of the social and health care sector. In Denmark, Iceland, and Sweden, a patchwork of strategies and initiatives seems to be the most correct expression of the efforts to recruit and retain health care staff. However, the overall agenda among the actors both within the countries and across the five Nordic countries is coherent and similar and will be explained in detail in the sections below.

\subsubsection{Initiatives - a comparative overview}

Table 6.1 summarises various initiatives across the Nordic region, categorised according to whether they target the educational level or the workplace level (or both), and whether they focus on recruiting new students/personnel or retaining students/employees (or both). The initiatives in the table have been given priority by the central political actors in the respective countries, but strategies are not incorporated in the table. 
Table 5.1: Initiatives to improve recruitment and retention in the educational sector and in the workplace in the Nordic region

\begin{tabular}{|c|c|c|c|c|}
\hline & \multicolumn{2}{|c|}{ Education } & \multicolumn{2}{|c|}{ Workplace } \\
\hline & Recruitment & Retention & Recruitment & Retention \\
\hline $\begin{array}{l}\text { Examples of } \\
\text { initiatives }\end{array}$ & $\begin{array}{l}\text { Campaigns } \\
\text { Increased intake } \\
\text { New educational } \\
\text { programmes }\end{array}$ & $\begin{array}{l}\text { Mentoring pro- } \\
\text { grammes } \\
\text { Reforms }\end{array}$ & $\begin{array}{l}\text { Attracting foreign } \\
\text { health care per- } \\
\text { sonnel } \\
\text { Campaigns }\end{array}$ & $\begin{array}{l}\text { Employment terms } \\
\text { Work/life balance } \\
\text { Working environment } \\
\text { Continuing education and } \\
\text { training } \\
\text { Management } \\
\text { Talent management }\end{array}$ \\
\hline Denmark & $\begin{array}{l}\text { "White Zone," Reform } \\
\text { of educational pro- } \\
\text { grammes, } \\
\text { DM in Skills } \\
\text { "The SOSU's" } \\
\text { University college } \\
\text { reform and reform of } \\
\text { educational pro- } \\
\text { grammes } \\
\text { Increased intake } \\
\text { "Change job, not } \\
\text { gender!," "MPower" }\end{array}$ & $\begin{array}{l}\text { University College } \\
\text { reform } \\
\text { Reform of educa- } \\
\text { tional programmes }\end{array}$ & $\begin{array}{l}\text { "More Men, } \\
\text { please" } \\
\text { Policy on full-time }\end{array}$ & $\begin{array}{l}\text { New educational } \\
\text { programmes } \\
\text { "More Men, please" } \\
\text { Policy on full-time work } \\
\text { Focus on continuing } \\
\text { education } \\
\text { Focus on ways to reduce } \\
\text { sick leave }\end{array}$ \\
\hline Iceland & Increased intake & & $\begin{array}{l}\text { Strategic focus on } \\
\text { recruiting doctors } \\
\text { and nurses }\end{array}$ & $\begin{array}{l}\text { Strategic focus on retain- } \\
\text { ing doctors and nurses }\end{array}$ \\
\hline Finland & $\begin{array}{l}\text { "Strengthen care" } \\
\text { Increased intake } \\
\text { New shorter education } \\
\text { for assistant practical } \\
\text { nurse (probationary } \\
\text { period) } \\
\text { Skills Finland }\end{array}$ & & $\begin{array}{l}\text { Pilot projects } \\
\text { recruiting foreign } \\
\text { personnel (outside } \\
\text { the Nordic region) }\end{array}$ & $\begin{array}{l}\text { National Development } \\
\text { Programme for Social } \\
\text { Welfare and Health Care } \\
\text { (Kaste) }\end{array}$ \\
\hline Norway & $\begin{array}{l}\text { Increased intake in all } \\
\text { levels of education with } \\
\text { a focus on both youth } \\
\text { and adults } \\
\text { Emphasis on academic } \\
\text { breadth }\end{array}$ & $\begin{array}{l}\text { More practical } \\
\text { vocational educa- } \\
\text { tional pathways. } \\
\text { Ensure apprentice- } \\
\text { ships for those } \\
\text { attending voca- } \\
\text { tional training }\end{array}$ & $\begin{array}{l}\text { Attracting more } \\
\text { men to work in the } \\
\text { sector } \\
\text { Attracting more } \\
\text { young people to } \\
\text { work in the sector } \\
\text { Interdisciplinary } \\
\text { recruitment }\end{array}$ & $\begin{array}{l}\text { Facilitate continuing } \\
\text { education/supplementary } \\
\text { training and career } \\
\text { opportunities for health } \\
\text { professionals }\end{array}$ \\
\hline Sweden & $\begin{array}{l}\text { VO-colleges } \\
\text { Increased intakes } \\
\text { to medical education } \\
\text { Improved specialized } \\
\text { course offerings for } \\
\text { physicians }\end{array}$ & & & $\begin{array}{l}\text { VO-colleges } \\
\text { Guidelines for required } \\
\text { competencies in staff } \\
\text { "Kompetensstegen" } \\
2005-2007 \\
\text { "Omvårdnadslyftet" } \\
2011-2014 \\
\text { National leadership } \\
\text { training for managers in } \\
\text { elderly care } \\
\text { Dementia ABC }\end{array}$ \\
\hline
\end{tabular}

Source: DAMVAD 2014, Country reports. 


\section{European collaboration}

As evident from the table, Iceland differs somewhat from the other countries in terms of the number of initiatives. This can mainly be explained by the size of the Icelandic population, which is below that of the larger cities in the rest of the Nordic countries. Iceland, as well as the other Nordic countries, participates in the "Joint Action Health Workforce Planning and Forecasting" (JAHWF), which is funded by the Health Programme of the European Union (www.euhwforce.eu).

This joint European project ${ }^{10}$ works towards:

- Better monitoring by access to timely data.

- Updated information on mobility trends.

- Guidelines on qualitative and quantitative planning methodology.

- Estimation of future skills and competencies needed for the health workforce (HWF).

- A platform for cooperation to find possible solutions on expected shortages.

- HWF planning and forecasts on policy decision making.

The JAHWF thus does not fit the table below, which takes educational and workplace levels as a starting point. However, this large-scale project reflects the fact that there is awareness at the European level as well. According to euhwforce.weebly.com, a shortage of no less than $1,000,000$ employees is expected in the European health care sectors by 2020 , and there is a focus on both quantitative and qualitative needs for health care professionals.

\subsection{Recruitment and retention in the educational sector}

Student intake within health education has increased in the Nordic countries during the past decade. In general, recruitment to study programmes is not a problem and has not been one in recent years, as there are generally more applicants than student intake.

In the Nordic countries, most of the educational programmes in health and social care are centrally regulated. However, steps have been taken to

${ }^{10} \mathrm{http} / / /$ www.euhwforce.eu/web_documents/RESULTS/JAHWF_D023_Leaflet_TBA.PDF 
boost the number of (qualified) applicants and retain students. These initiatives seek to increase the number of students as well as the quality at the educational institutions and the different educational programmes.

Interviewees stress that the limited possibilities for increasing student intake at educational institutions to secure the needs of the future are related to an overall societal and financial perspective, which is apparent in the Nordic countries, where the public sector by definition consumes a large proportion of the GNP. Even though some of the countries are still affected by unemployment in the wake of the financial crisis, workforces are declining, and an overall need for labour is expected in the future. Balancing the different sectors within the economy is thus important. Increasing intake within the health professions unlimited is not desirable from an overall financial and societal perspective, as growth is mainly, but not solely, generated in the private sector. Hence, the strategies related to recruiting and retaining health care professionals look at other solutions in addition to increasing the number of employees in the health care sector. These trends are outlined in this chapter.

Many of educational programmes combine theoretical studies with a practical approach in terms of mandatory work placement. This limits the possibility of increasing student intake from the central level. However, measures are now being taken in Norway to shift between training at school and at the workplace as part of the educational programme. The challenge in Denmark and Iceland has been a lack of coherence between the need for educated health care professionals and the supply of apprenticeships (DAMVAD, 2013). However, as a general trend, intake rose in the Nordic countries during the 2000s.

Retention within educational programmes have not been given the same attention in recent years as in the early 2000s in the Nordic countries. The recession partly explains this, as rising unemployment has made it harder to drop out and get a job. However, in Norway, and Denmark to some extent, the health care worker vocational education is experiencing difficulty retaining students. The lack of coherence between the theoretical and practical parts of the education, as well as the low status of the profession, have been mentioned as important factors. This discourse, which is present in the other Nordic countries as well, can be difficult to change overnight. According to the interviewees, the low status may be reinforced by politicians' tendency to direct young people with low skills and other challenges towards these professions. The initiatives "DM in Skills" in Denmark, "YrkesNM" in Norway, "Skills Finland," etc. attempt to changing the status of the job of health care workers. They are part of a high-profile project where over 40 vocation- 
al educations are represented, either as competitors or presenters. The hope is to use this annual event to improve the image of vocational training by creating awareness about its importance, thus attracting highly qualified students to vocational education.

\subsubsection{Recruitment campaigns}

Even though the current need for health care professionals in the Nordic countries is described as "manageable', a range of traditional recruiting campaigns have been initiated in order to address it. The Norwegian initiative "Become a health worker" (Bli helsefagsarbeider) and the Danish campaign "White Zone" (Hvid Zone) are examples. Even though some of the campaigns were initiated 3-5 years ago, several of them are still running.

Gender has been a large component of these recruitment campaigns. This partly reflects a general concern with the gender-segregated labour markets of the Nordic region, but the gender-focused campaigns were also launched due to the expected shortage. Prior to the financial crisis, the demand for health care professionals was very high, and it was deemed necessary to recruit more men to meet the future demand. The supply of unemployed men rose after the financial crisis, which had a very negative impact on the building industry in the Nordic countries, among other sectors. Efforts were made to inspire and encourage men to make a career shift towards the care and social sector. The Finnish campaign "Strengthen care" (Styrka at omsorgen - voima hoivan) and the Norwegian "Men in health care" (Menn i Helsevesenet) as well as the Danish "Change job, not gender!" (Skift job, ikke køn!) and "MPower" are examples of recruitment campaigns with an explicit gender focus.

Creating new educational programmes is another way of boosting the number of health care professionals. This was contemplated in Sweden in the comprehensive proposal "Elderly Assistant - a profession for the future" in 2008, but never completed. In Finland, a new education for assistant practical nurses has been carried out for a trial period, but the initiative has not yet been evaluated. In general, some scepticism was identified in Finland, where the perception among professional organisations is that a short education as an "assistant" generally does not improve the status of a profession. High status is important in order to attract skilled students who can meet the requirements of the future health care sector. Taking the gender perspective into account, establishing a new, shorter education in an area that is traditionally dominated by women may reinforce a gender-segregated labour market (Berntson, 2001). 


\subsubsection{Does higher quality lead to better retention?}

In addition to recruitment campaigns, initiatives to enhance the quality and relevance of educational programmes have been launched in Norway, Sweden, and Denmark. The aim is to make sure that the educational programmes meet future needs and that educational institutions are able to attract and retain qualified students.

The Danish reform that led to the establishment of university colleges and business academies in 2007 is a prominent example of an educational reform that sought to strengthen the quality and relevance of educational programmes in the health care sector. In addition, the 2014 "Next Practice" proposal followed several strategic papers launched by Local Government Denmark $(K L)$. Its goal is to ensure that educational programmes match society's needs by making sure that students acquire competences that enable them to support the trend in the health care sector. The proposal stresses that a central theme in the development of the health care sectors in the Nordic region is the coherence and cooperation between the different administrative levels, which requires new competency among health care staff. This is also evident in Sweden and Norway, where the focus on the importance of educational programmes that meet future needs has been pronounced. In Norway, the White Paper Education for Welfare (Meld. St. 13 (2011-2012)) illustrates this. It has two main perspectives: 1) the needs of society and patients should define the content of health education; and 2) the goal is to create coherence between the demand for competency in the health and welfare services and the educational programmes.

In Sweden, a major initiative was launched in 2012, which focused on the quantitative and the qualitative need for health care professionals. This initiative,'Regional health and care colleges', aims to inspire local organisations (employers, professional organisations, and educational institutions) to cooperate on recruiting new students and people already educated in the care sector. The initiative shows that the Swedish authorities also pay attention to the crucial link between employers and educational institutions and focus on the importance of educational programmes that meet the needs of the future health care sector. 


\subsection{Recruitment and retention in the workplace}

At the workplace level, most initiatives are related to retention of employees as opposed to recruitment.

\subsubsection{Quality above quantity}

As indicated, upgrading the skills of employees is important in all the Nordic countries.

In Norway, the aspect of upgrading the skills of health care personnel is mainly seen in the "Competence Plan 2015." The "Competence Plan 2015" is part of the "Care Plan 2015" and is the Norwegian government's overall strategy to promote adequate, competent, and stable staffing in the care sector (Meld. St. 16 (2010-2011)). The measures promoted meet the challenges presented in the White Paper National Health and Care Services Plan (2011-2015) (Meld. St. 16 (2010-2011)).

The "Competence Plan 2015" promotes different goals related to the competency of staff in the health care sector, among others:

- Raising the educational level (formal education) in the care service, for example by increasing the proportion of employees with higher education.

- A greater academic breadth in the sector (representation of several professional groups and increased interdisciplinarity).

- Improving guidance, internal training, and continuing education and training.

Another measure in the "Competence Plan 2015" are related to the qualifications of staff: supply of competency must be secured through training, continuing education, trade examinations, and assessment of prior learning and work experience for different personnel groups without education, as well as training from the health work educational programme in upper secondary education. Another theme is the geographical distribution of educational institutions. The government wishes to support decentralised colleges by providing stimulus grants for decentralised courses at the college level to ensure consistent provision of college-educated personnel in rural municipalities.

The central initiative in Sweden, "Strengthening care of the elderly" (Omvårdnadslyftet) is running from 2011-2014. It is very similar to a previous initiative, the "Skills Escalators Programme" (Kompetensstegen), which was launched in Sweden in 2006. Both initiatives 
allow Swedish municipalities to apply for funding for various projects that can improve care of the elderly by primarily focusing on continuing education among health care staff already working in the municipalities. Initiatives relating to continuing education are also present in the rest of the Nordic countries. Interviewees stress that what is needed in the municipalities, and at hospitals in particular, are educational programmes that take the "clinic" (i.e. a practical approach) as their starting-point. For example, in Denmark, nurses are educated to perform intestinal screenings at hospitals, while they work as nurses. This type of screening is normally a task for a doctor. However, to meet the future needs of the health care sector and spend resources in the best possible way, there is a transfer of tasks between health care professionals (task delegation), and interdisciplinary teams are gaining ground.

The interviews in Denmark, Norway and Sweden highlight that there are challenges related to the focus of continuing education. A general trend to develop new study programmes and focus on tertiary education has been identified in the Nordic region. However, according to the interviewees, some of the educational programmes are overly academic, and hence do not prepare students/employees for the practical life at hospitals and in the care sector. At the same time, a Master's degree increases the salary and status of a profession, which is an important goal for professional organisations and individuals. The opportunity to pursue postgraduate studies is a signal to students/employees that it is possible to build a career in the health professions. This may ultimately increase interest in basic health education, as future career possibilities have proven to be important when people make career choices. However, there is a risk that some postgraduate programmes lead employees to a career behind a desk, far from the hospital. This poses a challenge since the health care sectors mainly need "warm hands" in the years to come.

The explicit need for "warm hands" is also emphasised in Finland, where the above-mentioned general strategy emphasises that the demand for labour in the health care sector can only be met by means of personnel policy, management interventions, and development of new working methods. Examples are increasing productivity, developing skill sets, advanced roles for nurses, multi-professional teams (interdisciplinarity), collaboration and preventive services, using applied e-health technology, supporting patients' capacity for "help to self-help," etc. The distribution of professional responsibilities between groups of professionals in the health care sector has been promoted through legislative changes and regional and local pilot projects, which are supported through the health policy programmes adopted by the Finnish govern- 
ment. These regional and local initiatives can be seen in the light of the central strategy, the National Development Programme for Social Welfare and Health Care (Kaste), which focuses on areas such as the need to improve services for the elderly. ${ }^{11}$

To sum up, continuing education is widely used strategically to meet the future needs of the health care sector in the Nordic countries. However, from the employers' perspective, the practical approach to continuing education is of paramount importance to ensure that there are enough hands at hospitals, nursing homes, and in home care in the future.

\section{The importance of a good work environment}

An ongoing, albeit not new, challenge related to retention of health care professionals, is short-term and long-term sick leave. The health care sectors generally have a tough physical and psychological working environment. In Sweden, for example, the local and regional levels of sick leave are higher than in the private sector, ${ }^{12}$ and this pattern is mirrored in Norway and Denmark. A common explanation has been the type of work, as it has been pointed out that public employees work more with people than do employees in the private sector. While this challenge is often dealt with at the local level, the challenges related to sick leave are addressed at a central level in Norway through the major Norwegian initiative the "Competence Plan 2015," along with a range of prominent challenges. This is part of the Norwegian government's "Care Plan 2015" general strategy to stimulate adequate, competent and stable staffing in the care sector. The specific focus on reducing sick leave by promoting a good working environment is dealt with in an agreement between the Norwegian Government and the Norwegian Association of Local and Regional Authorities, KS.

One of the Danish interviewees describes the policies for retaining employees, including reducing sick leave, as "life blood" for the municipalities, indicating that many concrete initiatives take place locally in the municipalities in the Nordic region.

The "Competence Plan 2015" also addresses the challenges relating to part-time work in the Norwegian health care sectors, where many employees do not work full-time. In Norway, as many as $2 / 3$ of the workers work reduced hours in some municipalities. In Denmark, a recent mapping reveals that $1 / 3$ of employees at hospitals do not work

\footnotetext{
$11 \mathrm{http}: / /$ www.stm.fi/en/strategies_and_programmes/kaste

12 http://www.scb.se/Pages/TableAndChart__20533.aspx
} 
full-time. This is problematic on several counts. First, the large number of people who work part-time is obviously problematic, considering the present and future lack of staff in the health care sectors. In Norway, this means that many unskilled workers find employment in the health care sector, which is not desirable in terms of the aforementioned focus on quality, patients' security, and the increased requirements regarding the competency of health care staff. Second, the widespread use of part-time employees is thought to reinforce the wage gap between men and women because more women work part-time. In Denmark, a "policy on fulltime"13 has been agreed on by the regions' organisation, Danish Regions. This means that only full-time positions will be offered at Danish hospitals from 1 January 2014. The policy was adopted to meet future staffing needs at the hospitals, as it is expected to attract health care professionals overall. At the same time, it is acknowledged from a central political level that Denmark (and the other Nordic countries) will need people in the workforce in the years to come. From that perspective, it is not considered appropriate that too many employees work part-time.

\subsubsection{Welfare technology and more volunteers - a different approach to future needs}

Due to a lack of financial and/or human resources, it is not possible to educate and hire enough personnel to meet the rising need in the health care sectors in the Nordic region. The Nordic countries are therefore exploring strategies beyond hiring more personnel in order to establish a coherent and high-quality health care sector. This influences the need for competency and the need to recruit and retain, because some of the strategies have the potential to substitute staff in the health care sector.

Welfare technology is seeing a rapid development in the health care sectors as a whole.

We define welfare technology as technology than can help and assist users in their daily lives, and staff in their working lives. Examples of welfare technology are intelligent aids like cleaning robots, sensors in clothes, smart homes, and tools that help personnel plan shifts, routes, etc.

${ }^{13} \mathrm{http} / /$ www.regioner.dk/ /media/Mediebibliotek_2011/ARBEJDSGIVER/Arbejds\%20og\%20ans\%C3\%A6ttelsesret/Politik\%20om\%20fuldtid_2013.ashx 
Dedicated strategies focusing on welfare technology have been launched recently ${ }^{14}$ in Norway, Sweden and Denmark. In Finland, strategies related to the use of welfare services are embedded in the aforementioned Kaste programme. Welfare technology can both increase quality and efficiency and replace personnel. Taking the mantra "help to self-help" from the new home care paradigm as an example, it is only necessary to teach an elderly user how to use a cleaning robot once - after that, the robot does the job. Telemedicine is also widespread. Fewer resources are spent if the health professional does not have to visit the elderly, but can communicate with them via a computer.

The use of volunteers is another widespread trend, especially in Norway, Finland and Denmark. The welfare state is expected to rely heavily on volunteers in the years to come. Thus, volunteers are now handling some of the tasks that were previously reserved for employees, such as taking the elderly person for a stroll or reading the newspaper with them. Money is saved while the volunteer is believed to deliver a different and valuable service that complements the service provided by the employee who offers care as a part of his or her paid work. Hence, there is great interest in integrating volunteers into the health care sectors. This is combined with a focus on doing this in the best possible way with respect for the citizen, the employee, and the volunteer.

\subsection{Concluding remarks on strategies and initiatives}

The strategies pursued at the central political levels are clear and appear to be very similar in the Nordic countries. However, as indicated, Norway is the only country that has launched a major strategy to address the future needs in the health care sector.

It is evident that both the educational level and the workplace level are addressed in the strategies. At the educational level, recruitment campaigns have been launched to attract students, and intake has been increased by changing the dimensioning of the health care educations in the 2000s. With regard to retention, reforms of educational programmes and structural changes of the educational systems appear to be the most frequently applied method. However, there are challenges related to

14 Norway: Innovation in the Care Services (2013), Sweden: National e-Health Strategy (2010) and Denmark: Strategy for Digital Welfare (2013) and National Action Plan for the Dissemination of Telemedicine (2012). 
retaining students associated with vocational training to become a health care worker. Initiatives to retain students and dropout analyses are often launched locally at institutions and are therefore not identified in this analysis.

At the workplace level, initiatives are mainly taken to retain personnel. Both Finland and Denmark have previously launched initiatives to recruit foreign personnel. However, in the current financial situation, these initiatives appear to have lost most of their relevancy, and at present there is no active recruitment of foreign personnel. The initiatives identified are related to the aforementioned focus on quality and coherence in the Nordic health care sectors. This creates a need for development of competency, task delegation and interdisciplinarity among health care professionals, which more than anything calls for upgrading the skills of health care professionals.

\subsection{Future prospects}

As evident from the sections above, the future of the health care sectors in the Nordic region and the challenges facing the countries are high priorities in Denmark, Finland, Iceland, Norway, and Sweden. However, the shortage of health care professionals generally appears to be embedded in an overall discussion concerning the future of the health care sectors, as it relates to the general development in the Nordic health care sectors. This does not mean that concrete initiatives regarding recruitment and retention have not been launched. Table 5.1 and the analysis of the strategies and initiatives in this chapter point to the opposite. For instance, continuing education is widely used to ensure that health care professionals find interesting jobs with access to a higher salaries and professional development. At the same time, continuing education is considered necessary to raise the quality and strengthen the coherence of the Nordic health care sectors. It can therefore be concluded that a sole focus on recruitment and retention is too narrow an approach, as it does not grasp the full complexity of the reality of the Nordic health care sectors.

In addition, this report concludes that despite some differences in the health care systems, the Nordic health care sectors share many similarities. Most important is free and equal access to health care of high quality and a system that is predominantly financed through taxes. In addition, the systems are politically controlled by decentralised administrative levels through democratic processes. 
There seems to be a similar perception of the challenges related to the future health care systems in the four largest Nordic countries. They are related to a changing demography, limited financial means, and the task of ensuring a coherent health care sector of high quality. The challenges have found their expression in a changed paradigm focusing on everyday rehabilitation and "help to self-help," which affects the choice of overall strategies in the countries. It is thus likely that inspiration and good practices can be shared among the Nordic countries.

The potential within task delegation and interdisciplinarity through multi-professional work environments in particular seems to be an obvious option for increasing cooperation in the Nordic region. In all of the Nordic countries, the trend points towards increased task delegation in order to use resources the best possible way. Development of shared educational courses within the Nordic countries may be an option, as the disease patterns are generally similar in all of the countries. It is likely that an idea in Finland concerning a specific task can be applied in Denmark or Iceland. In addition, cooperation forums, which allow sharing of good practices and experience with task delegation could be an opportunity in a Nordic context.

It further seems obvious to take advantage of the similar organisation of the care of the elderly in Denmark, Norway, Iceland, Sweden and Finland. For instance, shared experiences concerning continuing education of health care workers in the municipalities could be one way of cooperating across Nordic borders to ensure quality and enough good health care workers in the future. An increased focus on what works and proven results is key in all of the countries. One option could be to identify municipalities in Denmark, Finland, Norway, and Sweden that have succeeded in upgrading the skills of their health care workers. In-depth analyses of local initiatives, as well as interviews with health care workers in the four countries could provide more knowledge regarding the future of care of the elderly in the Nordic region.

At the same time, recent initiatives like the policy on full-time work in Denmark and the establishment of regional health and care colleges in Sweden are of obvious relevancy to the other countries. The monitoring and follow-up of these initiatives is extremely valuable in a Nordic context. 


\section{Lack of knowledge}

The previous chapters have provided a comparison of the framework conditions of the Nordic health care sectors, the future challenges within the sectors, and the strategies followed and initiatives launched to mitigate these challenges. However, it is evident from the previous chapters that there is a lack of knowledge throughout the Nordic region within these important areas. Lack of knowledge is the topic of this chapter.

\subsection{Do the reforms lead to more coherent health care sectors?}

The lack of knowledge regarding the framework conditions is related to the organisational changes experienced by some of the health care sectors in recent years. We still do not know whether the reforms will lead to a more coherent health care sector and provide efficiency and higher quality services, which is the ultimate goal.

In Norway, the "Coordination Reform" poses future challenges in the care sector by particularly affecting local government and municipal service. It will therefore be interesting to see how municipalities handle the increased responsibility through priorities and service provision given their financial framework and leeway. It will also be interesting to obtain more knowledge about the consequences of the reform, especially for the municipalities, in line with the growing challenges in the sector in coming years. NOK 35 million have been allocated to evaluate the "Coordination Reform" in 2012-2015.15

In Denmark, the 2007 local government reform has been evaluated. The evaluation points to challenges related to coordination and cooperation between the Danish administrative levels in the health care sectors; i.e. the regional and the local levels. The government level has sought to mitigate this through changed requirements regarding the annual negotiations between the regions and municipalities (sundhedsaftalerne). It

15 http://www.forskningsradet.no/no/Utlysning/EVASAM/1253973304455 
remains to be seen whether this approach will lead to a more coherent Danish health care sector.

As shown in the report, Iceland deviates from the other countries to some degree. This has to do with the aforementioned smaller size of the population, which affects the framework conditions, the challenges, and the strategies and initiatives. Despite the relatively recent reform in 2007, steps are being taken to change the Icelandic health care system again. A report from the Boston Consulting Group (2011) identifies opportunities for short-term savings and, more importantly, a long-term health care reform. No legislative changes have been made in the wake of the report, but small adjustments have been initiated. Services for the elderly have hitherto largely been the responsibility of the state as described in chapter 4 . However, in the next few years, responsibility is expected to shift to the local authorities. The goal is to transfer services closer to residents and strengthen the role of local government. However, at this stage it is unknown how this intended change will affect the health care sector in Iceland in terms of the demand for health care professionals and the need for competency. A stronger local government will bring the Icelandic health care sector closer to the rest of the Nordic countries and thus improve opportunities for shared initiatives.

In Finland, a local government reform is currently being prepared that will be implemented in 2015. Some of the same trends as in Norway and Denmark are evident. Its goal is to reorganise services for a broader population base and for greater entities than at present in order to ensure that the population can obtain equitable services of high quality. Due to the municipalities' prominent role in Finland in relation to the organisation of hospitals and the care sector, the reform will have a major impact on the organisation of the Finnish health care sector. Concrete results remain to be seen.

\subsection{How can we accuretely predict the future need for personnel?}

At this stage, we have much knowledge about the present situation with respect to the supply and demand for relevant expertise in the health care sectors, current user groups, and services offered today. The chapter on challenges thus provides a fairly clear picture of the main trends and challenges in the Nordic region within the Nordic health care sectors.

However, there is always a degree of uncertainty when forecasting future demographic trends - including future staffing needs. Forecasts are 
based on assumptions regarding developments in fertility rates, mortality rates, and migration. Migration patterns are particularly difficult to foresee. One reason is that there are different types of migration (labour migration, refugee migration, close-relative migration) that are shaped by different underlying factors. The main reason is that it is very difficult to predict financial growth, which affects labour migration, and political developments, which affect refugee migration in different countries.

We know that there will be fewer employees to take care of a growing group of elderly. As highlighted in chapter 4, various predictions have been made in the Nordic countries. However, none of the predictions are very precise, and it is impossible to state the exact number of health care professionals that will be needed in the Nordic region in the future. In addition, there is a lack of regional and local predictions in the Nordic countries. Such forecasts have proven to be very important due to an ongoing urbanisation in the Nordic countries, especially among young people who leave rural areas and often stay in the bigger cities after finishing their education. Predictions that consider the regional and local levels are important in order to make sure that the right steps are taken to meet the challenges in the best possible way.

The problems relating to exact predictions also stem from the presence of some of the other trends accounted for in this report. The continuous development and inventions in technology and medical knowledge, for instance, impact the need for health care professionals. Examples include the changes described in working methods with an interdisciplinary approach, sharing of expertise across administrative levels and professions, and responsibility and flexible task performance among different health care professionals.

Another significant uncertainty factor in the predictions related to the future need for health care professionals is how the diseases of the new generation of seniors will evolve. It is an open question whether research will lead to new methods of treatment in the medical areas of e.g. lifestyle diseases, cancer, and dementia. This development will affect the type of health care professionals and the number of staff required in the Nordic health care sectors in the years to come. A prominent example of this is the challenges related to the elderly medical patient as described in chapter 4 . 


\subsection{What are the effects of different strategies and initiatives?}

In general, it is not evident whether the different initiatives have had the desired effect. This is related to the lack of thorough and valid evaluations of, for example, the recruitment campaigns carried out in the Nordic countries. As described, a prominent aspect in the recruitment campaigns has been gender considerations. However, there is a lack of studies regarding the extent to which campaigns have succeeded in attracting and retaining men and, more importantly, whether men remain in the health care sector after finishing their education.

Neither the strategies related to continuing education nor "flexible task performance" at workplaces have been subject to evaluation. However, studies from the UK with similar experiences have shown successful results, and it is thus likely that the same will be the case in the Nordic countries. 


\section{References}

Berntson, Maria (2001): Möjligheter med förhinder. Den nya lärarutbildningen och förskollärarna, Pedagogisk Forskning i Sverige, 6(3): pp. 206-217.

DAMVAD (2013): Velfærdsprofessioners og -uddannelsers attraktivitet og kvalitet $i$ Norden. Delstudium 2, Holdbar Nordisk Velfærd, Nordisk Ministerråd (http://www.norden.org/da/publikationer/publikationer/2013-920/delstudium2-velfaerdsprofessioners-og-attraktivitet-og-kvalitet-i-norden)

DAMVAD, 2014: Country reports (appendixes) on Denmark, Finland, Iceland, Sweden and Norway.

Finansministeriet (2009): Scenarier for det fremtidige behov for udvalgte faggrupper af uddannet arbejdskraft i den offentlige sektor (http://www.fm.dk/publikationer/ arbejdspapirer/2010/scenarier-for-det-fremtidige-behov-for-arbejdskraft-ioffenltig-sektor/ /media/Publikationer/arbejdspapirer/2010/2009_ Fremskrivninger.ashx)

Nordic Council of Ministers (2013): Nordic Statistical Yearbook, 2013, www.norden.org/facts

Vrangbæk, Karsten, Magnussen, Jon \& Richard B. Saltman (2009): Nordic health care systems - recent reforms and current policy changes, McGraw Hill, Open University press http://www.euro.who.int/_data/assets/pdf_file/0011/98417/E93429.pdf 



\section{Dansk resumé}

De nordiske velfærdsstater står, som resten af de europæiske lande, overfor store demografiske udfordringer i de kommende år, idet store grupper ældre forlader arbejdsmarkedet, mens mindre årgange træder ind. Dette mønster er udtalt i den offentlige sektor, særligt i kommunerne, der i de nordiske lande leverer omsorgsydelser til den store generation af ældre.

Samtidig medfører øget middellevetid, ældre med nye typer af sygdomme samt ny teknologi og nye behandlingsmetoder inden for sundhedssektoren, en øget efterspørgsel efter sundhedsydelser. Kombineret med en dalende arbejdsstyrke og økonomisk tilbageholdenhed i forhold til udgiftsstigninger, er spørgsmålet, hvordan der gøres bedst brug af penge og ansatte i sundhedssektoren.

De Nordiske lande ligner hinanden på mange områder, eksempelvis hvad angår en omfattende offentlig sektor og opbygningen af sundhedssystemerne. Derfor er en af konklusionerne i rapporten, at disse ligheder i organiseringen af sundheds- og omsorgssektorerne er et godt udgangspunkt for at udvikle fælles tiltag og initiativer på tværs af de nordiske lande.

Endvidere viser rapporten, at de nordiske lande, om end i forskelligt omfang, står over for en mangel på ansatte i sundhedssektoren i de kommende år, hvilket er særligt udtalt i visse geografiske områder i Norden. Det til trods er det fælles for de nordiske lande, at de centrale, politiske aktører ikke kun er optagede af at sikre antallet af sundhedsprofessionelle, men i høj grad er fokuserede på at sikre kvaliteten og sammenhængen i de nordiske sundhedssektorer fremadrettet. Dette kommer til udtryk i strategier, der udtrykker krav og ønsker om udvikling af de sundhedsprofessionelles kompetencer. Desuden er der et stort fokus på velfærdsteknologi, frivillighed og øget effektivitet etc., hvilket er med til at ændre kompetencebehovene og således stille nye krav til de kommende generationers sundhedsprofessionelle. Ydermere er det en pointe, at disse tendenser potentielt kan være med til at mindske behovet for sundhedsprofessionelle fremover.

Analysen af strategier og konkrete initiativer i de nordiske lande, der adresserer manglen på sundheds- og omsorgspersonale viser, at de kvantitative behov (forstået som antallet af ansatte) i høj grad overskyg- 
ges af nogle mere kvalitative behov (relateret til de ansattes kompetencer og organiseringen af sundhedssektorerne).

Især i Danmark, Finland, Norge og Sverige er man optaget af spørgsmål vedrørende kvalitet og sammenhæng i social- og sundhedssektorerne. Analysen af initiativerne viser samtidig, at man primært fokuserer på at rekruttere til uddannelserne ved at arbejde med kvaliteten i uddannelserne samt at fastholde medarbejdere på arbejdspladsen ved at have fokus på efter- og videreuddannelse, der øger kvaliteten i sektoren samtidig med, at man tilgodeser medarbejdernes behov for faglig og personlig udvikling.

Rapporten peger endvidere på, at der på visse områder mangler viden, der kan være nyttig, når det skal vurderes, hvorvidt der er basis for at intensivere det nordiske samarbejde om at rekruttere og fastholde personale I sundheds- og omsorgssektoren.

Den manglende viden relaterer sig blandt andet til fremskrivninger vedrørende den præcise mangel inden for relevante professioner. Denne viden er vanskelig at opnå, men der er i de nordiske lande enighed om vigtigheden af at fortsætte arbejdet med at lave så præcise fremskrivninger så muligt og tilpasse strategierne hertil.

Andre tvivlsspørgsmål relaterer sig til den omstrukturering af de nordiske sundhedssektorer, der har fundet sted for nylig (i Island, Danmark og Norge) og vil finde sted i de kommende år (i Finland og formodentlig Island). Før de juridiske og organisatoriske ændringer er fuldt implementeret, er det ikke muligt til fulde at kende effekterne (og dermed potentielle problematikker) heraf, hvilket har betydning for eventuelle ændringer i opgavefordelingen mellem de administrative niveauer og sundhedsprofessionelle, incitamentsstrukturer etc.

I forhold til de anvendte strategier samt de lancerede initiativer kan det konstateres, at der mangler dybdegående og valide evalueringer heraf. Dette relaterer sig blandt andet til vanskeligheden ved at måle præcise effekter af eksempelvis rekrutteringskampagner. Desuden har vi stadig til gode at se konsekvenserne af nyligt igangsatte tiltag, som eksempelvis udrulningen af en politik om fuldtid, der blev igangsat på de danske hospitaler pr. 1. januar 2014.

Denne rapport er udarbejdet som led i Nordisk Ministerråds program Holdbar Nordisk Velfærd. 


\section{Appendixes Country reports Introduction}

How can the Nordic model be further developed and revitalised? The programme Sustainable Nordic Welfare launched by the Nordic Council of Ministers aims at finding new and innovative welfare solutions in the Nordic Region. Solutions that can contribute to increased quality and equality in education, work, and health for the 25 million inhabitants of the Nordic Region.

This appendix is composed of five country reports describing Denmark, Finland, Iceland, Norway, and Sweden, respectively. Each country is described in detail within the following three areas:

- Framework conditions of the health care sectors.

- Future challenges within the Nordic health care sectors.

- Strategies and initiatives initiated to mitigate the challenges.

It should be mentioned that the level of attention paid by national authorities to the challenges related to recruiting and retaining health care personnel varies considerably among the Nordic countries. While Norway is expectedly encountering the biggest challenges with regards to lack of personnel in the future, the country also seems to have the most comprehensive strategy for dealing with the challenge. This is reflected in the level of detail of the country reports in the appendix.

The sections on framework conditions sum up the most important legal, organizational, and financial characteristics of the health care sectors in the Nordic region. The five chapters highlights the conditions embedding the different methods and strategies used to recruit and retain staff within the Nordic health care sectors.

The sections on challenges describe the challenges relating to the future of the health care sectors in the five Nordic countries. The sections focus on the demographic development, the size of the workforce, and number of students within health professions. In addition, the most prominent challenges within the five different health care sectors seen from the central political levels in each country are discussed in the chapters. 
The sections on strategies and initiatives deal with the countries' strategic responses to the identified challenges. Policy papers and concrete initiatives, such as recruitment campaigns, are identified and discussed to the extent that they are launched centrally at the national level.

The most interesting and useful findings in the five country reports are summed up in the cross-sectional report "Recruiting and retaining health care personnel in the Nordic countries".

\subsection{Methodology}

The country reports are based on desk research and interviews with 2-7 people in each of the five countries, amounting to 24 people in total. The interviews are semi-structured, which is beneficial because it allows for certain topics to be discussed in all five countries, while simultaneously giving interviewees an opportunity to highlight the most pressing concerns and predominant strategies from their respective perspectives. In addition to interview data, the report makes use of national statistics in each of the five countries as well as numbers from the "Nordic Statistical Yearbook, 2013" (Nordic Council of Ministers, 2013). 


\section{Appendix 1: Denmark}

\subsection{Framework conditions}

\subsubsection{Judicial structure and organization}

The Danish health care system is regulated by law (Sundhedsloven, lov nr. 546 af 24. juni 2005). ${ }^{16}$ The last big reform of the health care sector was carried out in 2007 (Strukturreformen - the Local Government Reform). The reform created a new structure for Denmark, as 98 municipalities replaced the previous 271, 13 counties were abolished, and five regions were created. The five regions are; the Capital Region of Denmark, Central Denmark Region, North Denmark Region, Region Zealand, and Region of Southern Denmark. With the Local Government Reform, municipalities were given a more important and prominent role in the health care sector. The municipalities now have the overall responsibility for any rehabilitation that does not take place during hospitalization. This was not the case before the reform, where responsibility was shared with the counties. In addition, the municipalities have taken over the main responsibility for preventive treatment and promotion of health for citizens residing in the communes. As of January 1, 2007, the Danish municipalities gained responsibility for treatment of alcohol and drug abuse, and the municipalities are also responsible for specialized dental treatment for the mentally afflicted, etc., which was formerly the responsibility of the counties. The purpose of this structural change is to integrate preventive treatment and health promotion with the other local tasks, i.e. day care, schools, centres for the elderly, etc., in the close environment of the citizens.

With the Local Government Reform, the regions took over responsibility for health care from the former counties and are now responsible for hospital service, including psychiatry and health insurance, general practitioners, and specialists. The purpose of establishing five regions within the health care sector is to support the quality of patient care by

16 https://www.retsinformation.dk/forms/r0710.aspx?id=130455 
creating a basis for grouping treatments, taking advantage of specialization, and ensuring the best possible utilization of resources.

Citizens will often be in contact with both regional and the local levels (state, counties, and municipalities, respectively), and an ongoing point of interest for stakeholders across the three levels of government is to create a coherent system for the citizen, for instance after they have been discharged from hospital. As a means of obtaining coherence between the regional health sector and the local care sector, and ensuring correlation in treatment, rehabilitation, preventive treatment, and care, the regional and local councils are required by law to enter into binding agreements every four years in health negotiations (sundhedsaftaler). For instance, the Capital Region of Denmark has entered into an agreement with each of the 29 municipalities within this region. The National Health and Medicines Authority must approve each agreement. However, in practice, agreements within a region are standardized and only rarely contain details specific for an individual municipality. The six mandatory elements of these agreements are listed in the box below. ${ }^{17}$

The health negotiations (Sundhedsaftalerne) must address the six following topics:

- Hospitalization and discharge.

- Exercise programmes.

- Tools for assistance at home.

- Prevention and health promotion.

- The effort to help people with mentally disorders.

- Follow-up on unintentional incidents.

\subsubsection{Financing}

Expenditures at the municipality level are financed by locally collected taxes and are thus budgeted in each individual municipality. As the regions are not entitled to collect taxes, three kinds of subsidies finance health care at the regional level: A block grant from the state, a state activity-related subsidy, and a local activity-related contribution from

17 http://www.sst.dk/Planlaegning\%20og\%20kvalitet/Sundhedsaftaler.aspx 
the municipalities. Financing of the regions is legally defined in "Lov om regionernes finansiering". 18

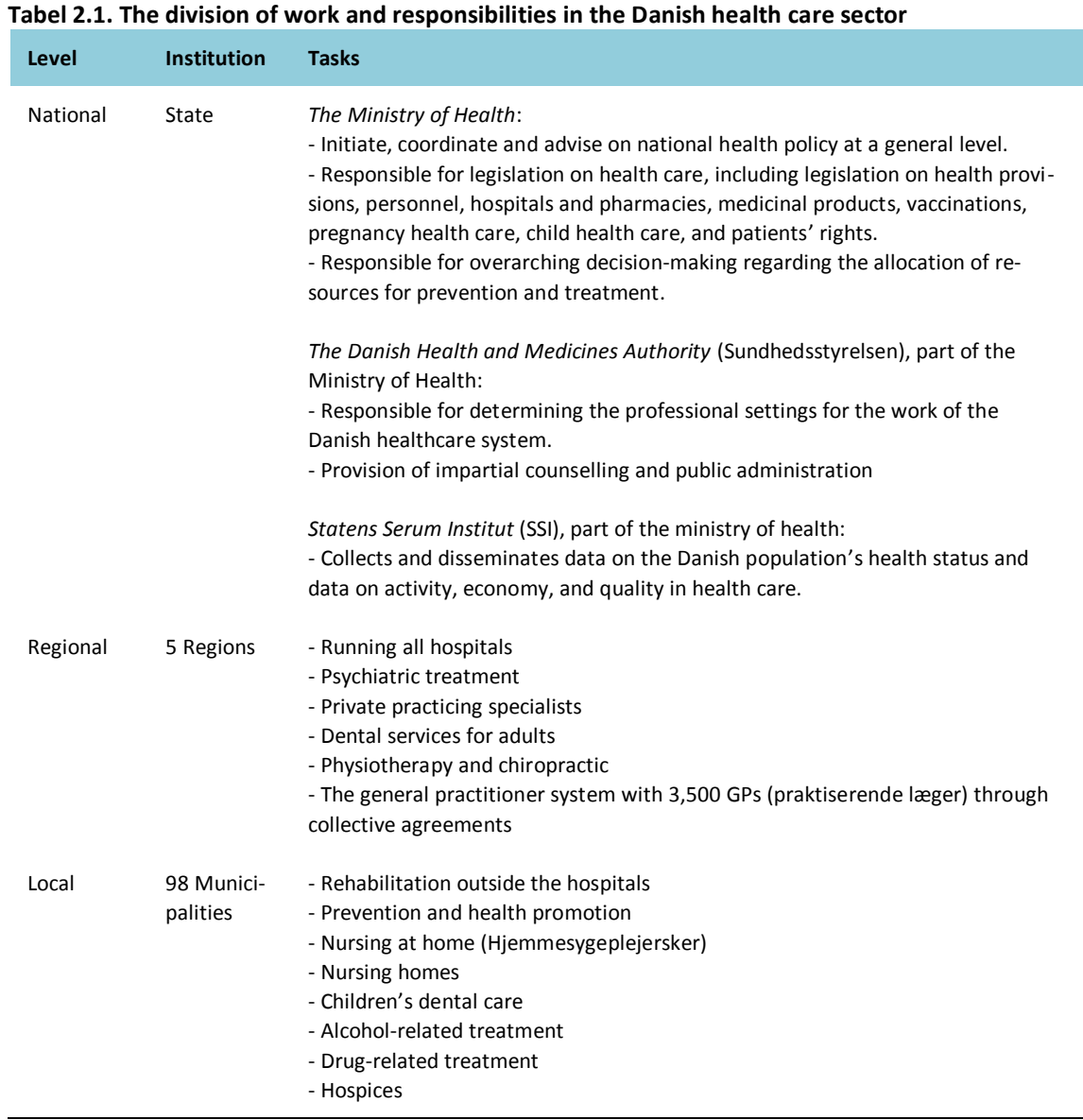

\section{Contributions from the state}

The regions' expenditures are part of the total public expenditures and aligned with Danish fiscal policy in general. Each year, the Danish Government and Danish Regions enter into agreements on the budgets of the regions (Økonomiaftaler). These agreements concern resources (level of expenditure and financing) as well as number of treatments in the hospitals (activity and production).

The state block grant constitutes the most significant element of financing - approximately $75 \%{ }^{19}$ In order to give the regions equal oppor-

18 https://www.retsinformation.dk/Forms/r0710.aspx?id=137895 
tunities to provide health care services, the subsidy is distributed according to a number of objective criteria reflecting expenditure needs (e.g. demography and social structure of each region).

Furthermore, part of the state financing of the regions is a state activity-related subsidy. The activity pool may constitute up to $5 \%$ of the health care expenditure of the regions. The purpose of the pool is to encourage the regions to increase the activity level at the hospitals.

The regions' total operational expenditure in the health care sector amounts to approximately 91 billion DKK (2011 figures), which constitutes about $9 \%$ of GNP.

In the coming 10-15 years, the Danish regions will make substantial investment in hospitals (building new "super-hospitals" as well as renovating and expanding existing hospitals). The government and the regions have agreed on investing 40 billion DKK in new hospitals.

\section{Local contributions}

Following the Local Government reform of 2007, municipalities are obliged to contribute to financing health care. As touched upon previously, when considering the new local health care tasks (preventive treatment, (elderly) care, and rehabilitation), the municipalities have acquired a more important role. The purpose of the local contributions is to encourage the municipalities to initiate efficient preventive measures for their citizens with regard to health issues. Since 2012, the local contributions have consisted solely of an activity-related contribution. The size of the contribution is dependent on the citizens' use of the health care sector and reflects mainly the number of hospitalizations and ambulant treatments. The contributions from the municipalities constitute approximately $18 \%$ of total financing of health care in the regions.

The municipalities' total operational expenditure in the health care sector amounts to approximately 26.4 billion DKK (2013 figures). 19,3 Billion (73\%) are transferred to the regions through the activity-related contribution.

19 http://www.ssi.dk/Sundhedsdataogit/Sundhedsoekonomi/ /media/ Indhold/DK\%20-\%20dansk/Sundhed sdata\%20og\%20it/NSF/Sundhed sokonomi/Finansieringen\%20af\% 20sundhedsv\%C3\%A6snetd.ashx 


\subsection{Challenges}

\subsubsection{Demographic challenges}

\section{More and older Danes}

The Danish population is expected to grow from 5,602,628 in 2013 to around 6,135,809 in 2050, which amounts to an increase of approximately $9 \%$. This is evident from table 2.2 below. The group of people aged 65 and above will by 2050 be $60 \%$ larger than today. This growth counters the $6 \%$ decrease in the group of people aged 40-64. The age groups younger than 40 will only increase slightly in this time period.

The Danes are becoming increasingly older, and rapidly so. From 1990 to 2010 the proportion of the population aged 65+ has been more or less constant around 15-16\% But from 2012, the proportion of the elderly is expected to increase each year for the next 30 years.

In 2042 , the $65+$ age cohort will amount to $25 \%$ of the Danish population. In 2014 , more than 1 million Danes will be 65 years or older.

By 2039, the number of elderly is expected to surpass 1,5 million, and in 2050, there will be almost twice as many Danes in their 70ies than children younger than 10 years.

The rise in the amount of elderly will be especially fast-paced in the first half of the period towards 2050. By 2020, those aged 65 or above are expected to grow by 230,000 , thus reaching more than $20 \%$ of the population for the first time.

\begin{tabular}{l|rrrrr}
\hline \multicolumn{7}{|c}{ Table $\mathbf{2 . 2}$ Population projection for Denmark by age and year } \\
& $\mathbf{2 0 1 3}$ & $\mathbf{2 0 2 0}$ & $\mathbf{2 0 3 0}$ & $\mathbf{2 0 4 0}$ & $\mathbf{2 0 5 0}$ \\
\hline Total & $5,602,628$ & $5,725,179$ & $5,923,334$ & $6,055,717$ & $6,135,809$ \\
$60-69$ years & 693,516 & 663,657 & 743,447 & 681,548 & 596,966 \\
$70-79$ years & 415,083 & 563,265 & 576,064 & 664,524 & 621,653 \\
$80-89$ years & 192,051 & 223,957 & 360,846 & 388,171 & 472,284 \\
$90-99$ years & 39,623 & 45,964 & 61,624 & 108,278 & 125,003 \\
100 years & 1,009 & 1,211 & 1,829 & 2,971 & 5,806 \\
\hline
\end{tabular}

Source: Statistics Denmark.

Generally, the proportion of elderly will be larger in peripheral than urban areas. The island municipalities and most municipalities in Northern Jutland, Southern Jutland, and Southern Zealand are projected to have a significantly higher percentage of elderly than the $20 \%$ national 
average by 2020. In contrast, the municipalities in and around the larger cities will have a lower share of elderly than the national average. For instance, by 2020, the share of people aged 65 or above is projected to amount to $11 \%$ in Copenhagen and $15 \%$ in Aarhus, whereas the number is projected to be $35 \%$ and $40 \%$ In the municipalities of Ærø and Læsø respectively. This uneven distribution of elderly is a big challenge for the municipalities.

\subsubsection{The Danish workforce and unemployment}

Based on the previous section, it is evident that less people will need to take care of a growing population of elderly in the very near future. Figure 2.3 visualizes the projection of the Danish workforce affiliation through 2050. The figure shows that the number of people outside the workforce exceeds the number of people in the workforce (age 18-64). This gap is predicted to increase continuously for the next 20 years before it starts decreasing and slowly stabilize towards the 2050. The gap looks drastic, and to judge from the level of debate and discussions by agenda setting actors, the challenges are serious. There is therefore and there is a need to focus on recruitment and retention. The strategies and initiatives pursued in order to mitigate these challenges will be discussed in further detail in section 2.3. However, it is worth mentioning here that today's increasing focus on self-care and welfare technology (meaning that most people can stay longer in their own home), illustrates a shift in the way elderly people are perceived. This changing mind set will be explained in greater detail in section 2.2.4.

In addition to looking at the overall workforce in Denmark, it is useful to take a closer look at the administrative levels and the sectors where people in the workforce are employed. People in the health care sector are primarily employed in the public sector, as the regions are responsible for the hospitals and the municipalities for elderly care, as highlighted in section 2.1.1. One exemption is the GP's who can be considered private practitioners and thus employed in the private sector. It is evident that the people working in the public sector are generally older than the private sector employees. Thus, the challenges associated with a decreasing work force are especially prominent in the regions and municipalities, as a relatively large share of the employed will be leaving the workforce and retire very soon. Numbers from the Danish employers' organization Local Government Denmark $(K L)$ show that whereas the group of people above the age of 55 constituted $15 \%$ of the general workforce in 2009, the number was around $30 \%$ within certain health 
professions such as nurses and health care workers, who have the main responsibility of elderly care.

Figure 2.3. Projection of Denmark's workforce affiliation

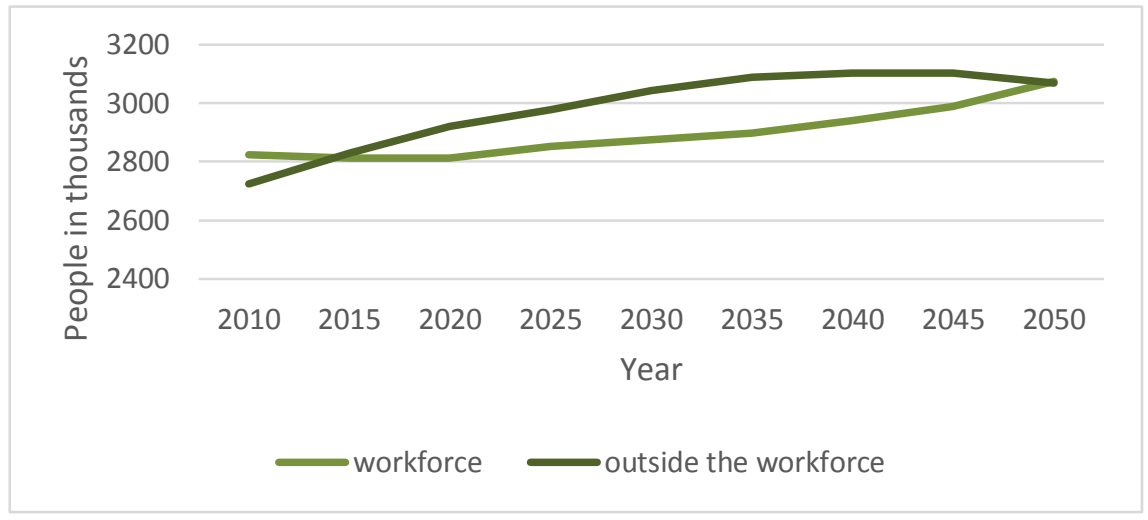

Source: DREAM's report on labour market affiliation (Fremskrivning af Befolkningens Arbejdsmarkedstilknytning) 2011, based on socio-economic projections and data from Statistics Denmark.

Table 2.4 shows the general registered unemployment in Denmark from 2000 to 2012. It can be seen that unemployment was very low in 2007 and 2008 before increasing during the financial crisis.

\begin{tabular}{cccc}
$\begin{array}{c}\text { Table 2.4. Unemployment in 1,000s in Denmark by year and gender } \\
\text { Year }\end{array}$ & Men & Women \\
2000 & 139 & 63 & 75 \\
2001 & 131 & 61 & 70 \\
2002 & 133 & 64 & 69 \\
2003 & 159 & 79 & 81 \\
2004 & 160 & 78 & 83 \\
2005 & 140 & 66 & 75 \\
2006 & 108 & 48 & 60 \\
2007 & 77 & 34 & 43 \\
2008 & 51 & 26 & 26 \\
2009 & 98 & 59 & 39 \\
2010 & 114 & 68 & 46 \\
2011 & 108 & 59 & 50 \\
2012 & 119 & 62 & 57 \\
\hline
\end{tabular}

Source: Statistics Denmark.

\subsubsection{Recruitment and retention of students and health professionals}

This section continues the quantitative view at the challenges facing the Danish welfare society with regards to recruitment and retention in the health care sector. 


\section{Recruitment in the educational sector}

At the beginning of the century, many of the Danish welfare educations experienced challenges in recruiting enough qualified students. This problem in combination with issues regarding dropouts led to concerns.

Table 2.5. Intake of students in ergotherapy by gender and year

\begin{tabular}{lccc} 
& Men & Women & Total \\
2002 & 48 & 466 & 514 \\
2003 & 45 & 486 & 531 \\
2004 & 49 & 483 & 532 \\
2005 & 52 & 476 & 528 \\
2006 & 44 & 491 & 535 \\
2007 & 51 & 474 & 525 \\
2008 & 53 & 411 & 464 \\
2009 & 57 & 463 & 520 \\
2010 & 72 & 522 & 594 \\
2011 & 74 & 558 & 632 \\
2012 & 99 & 547 & 646 \\
\hline
\end{tabular}

Source: The Student Register (INTE) Statistics Denmark.

Table 2.6. Intake of students in physiotherapy by gender and year

\begin{tabular}{lccc} 
& Men & Women & Total \\
2002 & 178 & 443 & 621 \\
2003 & 192 & 460 & 652 \\
2004 & 205 & 420 & 625 \\
2005 & 223 & 441 & 664 \\
2006 & 208 & 500 & 708 \\
2007 & 225 & 455 & 680 \\
2008 & 235 & 506 & 741 \\
2009 & 325 & 611 & 936 \\
2010 & 374 & 609 & 983 \\
2011 & 400 & 667 & 1,067 \\
2012 & 447 & 619 & 1,066 \\
\hline
\end{tabular}

Source: The Student Register (INTE) Statistics Denmark.

TABLE 2.7. Intake of students in nursing by gender and year

\begin{tabular}{lccc} 
& Men & Women & Total \\
2002 & 144 & 2,524 & 2,668 \\
2003 & 142 & 2,485 & 2,627 \\
2004 & 149 & 2,627 & 2,776 \\
2005 & 152 & 2,633 & 2,785 \\
2006 & 148 & 2,775 & 2,923 \\
2007 & 169 & 2,718 & 2,887 \\
2008 & 121 & 2,682 & 2,803 \\
2009 & 180 & 2,862 & 3,042 \\
2010 & 201 & 3,144 & 3,345 \\
2011 & 198 & 3,113 & 3,311 \\
2012 & 207 & 3,208 & 3,415 \\
\hline
\end{tabular}

Source: The Student Register (INTE) Statistics Denmark. 
TABLE 2.8. Intake of students in Social and Health Care (health care workers) by gender and year

\begin{tabular}{lrrr} 
& Men & Women & Total \\
2002 & 516 & 9,109 & 9,625 \\
2003 & 653 & 8,991 & 9,644 \\
2004 & 696 & 8,946 & 9,642 \\
2005 & 798 & 9,108 & 9,906 \\
2006 & 652 & 8,365 & 9,017 \\
2007 & 504 & 8,266 & 8,770 \\
2008 & 619 & 8,406 & 9,025 \\
2009 & 938 & 9,828 & 10,766 \\
2010 & 1,388 & 10,267 & 11,655 \\
2011 & 1,329 & 8,731 & 10,060 \\
2012 & 1,179 & 7,908 & 9,087 \\
\hline
\end{tabular}

Source: The Student Register (INTE) Statistics Denmark.

Note: In 2008 the two different Social and Health Care Educations (social og sundhedsassistent og social og sundhedshjælper) were gathered in one new program (social- og sundhedsuddannelsen). The different programs still exist but now as different levels in the same program. Statistics Denmark doesn't have the number of students at the different levels from 2008 , so we have combined the intake of the three programs before 2008.

TABLE 2.9. Intake of students in the medicine undergraduate program by gender and year

\begin{tabular}{lccr} 
& Men & Women & Total \\
2002 & 153 & 302 & 455 \\
2003 & 150 & 316 & 466 \\
2004 & 170 & 301 & 471 \\
2005 & 282 & 434 & 716 \\
2006 & 361 & 692 & 1,053 \\
2007 & 377 & 745 & 1,122 \\
2008 & 415 & 718 & 1,133 \\
2009 & 479 & 783 & 1,262 \\
2010 & 510 & 852 & 1,362 \\
2011 & 540 & 840 & 1,380 \\
2012 & 482 & 869 & 1,351 \\
\hline
\end{tabular}

Source: The Student Register (INTE) Statistics Denmark.

Note: The Danish University system has gone from being made up of an unseparated 5 years Master's program to being divided up in an undergraduate and graduate program. This change was initiated in 1993. Medicine was one of the last programs to undergo this change, and therefore some medicine students are not included in this table. This also explains the high increase in students over the years as the divided program becomes predominant.

As can be seen from tables 2.5-2.9 above, however, the social- and health related educations in Denmark have seen a rise in student intake after the onset of the financial crisis in 2008. There has also been an increase in the number of applicants, as people choose education when there are less jobs to get. Partly due to an explicit focus on the issue in the Danish "job centres" (entities responsible for helping the unemployed find a job), men's share of applications for health care related education increased during the crisis. This trend is also related to the development in the construction sector, where men have traditionally been employed. This sector was negatively affected during the crisis. 
In 2001, the percentage of men in health care worker education was $5 \%$ In 2011, this number had grown to $14 \%$.

Source: Momentum, 2013 (Local Government Denmark's Newsletter).

Most of the health educations, however, have not experienced significant increases in student enrolment. The primary reason is that many of the health educations, such as nursing, are dimensioned. That is, the intake of students are controlled in from a central level by only allowing a certain number of students to enrol. Nevertheless, the dimensioned educations have also seen an increasing amount of applications. Thus, in 2013, the number of applicants to welfare educations such as nursing and social work (not a part of this study) increased by $23 \%$ and $21 \%$ respectively.

\section{Retention in the educational sector}

The retention of students is just as important as recruitment within the educational sector. Table 2.10 below shows the completion rate of students on the health educations. Looking at the table, it is evident that health care worker and ergotherapist students are similar in the completion patterns in that roughly three out of four complete their education, while the completion rate for nursing is a bit lower, and for medicine significantly higher. In general, the completion rates tend to increase with educational level, which is also the case for the health educations, nursing exempted. Thus, in 2011, the completion rate for all short educations (1-2 years, such as social and health care) was $70 \%$ The rate for all middle long educations (3-4 years, such as physiotherapy, ergotherapy, and nursing) was $78 \%$, and the rate for all long educations (5 years + , such as medicine) was $83 \%$.

In general, the completion rate for all students have increased since 2002. However, as shown in the figure, the number has been rather stable within the healthcare professions. This indicates that there is a potential for retaining more students within some of the health care professions. 
Table 2.10. Completion rate by year and study. Pct.

\begin{tabular}{|c|c|c|c|c|c|}
\hline & $\begin{array}{l}\text { Social and } \\
\text { health care }\end{array}$ & Ergotherapist & Physiotherapist & Nurse & $\begin{array}{r}\text { Medicine under- } \\
\text { graduate }\end{array}$ \\
\hline 2002 & 75 & 77 & 82 & 67 & 76 \\
\hline 2003 & 75 & 80 & 81 & 68 & 77 \\
\hline 2004 & 77 & 77 & 82 & 70 & 82 \\
\hline 2005 & 77 & 75 & 80 & 73 & 83 \\
\hline 2006 & 76 & 80 & 84 & 72 & 83 \\
\hline 2007 & 78 & 76 & 78 & 75 & 83 \\
\hline 2008 & 73 & 73 & 80 & 76 & 85 \\
\hline 2009 & 81 & 75 & 80 & 75 & 82 \\
\hline 2010 & 77 & 74 & 82 & 75 & 85 \\
\hline 2011 & 74 & 73 & 81 & 73 & 83 \\
\hline 2012 & 72 & 72 & 81 & 74 & 85 \\
\hline Total & 76 & 76 & 81 & 72 & 83 \\
\hline
\end{tabular}

Source: Statistics Denmark.

\section{Recruitment and retention at the work place}

Newly educated health professionals do not necessarily continue their careers within the health care sector upon completion of their studies. Thus, it is a task in itself to recruit and retain professionals at the workplace by making sure that the sector is attractive for everyone.

Regarding the general recruitment and retention within nursing, an analysis from 2008 shows that 9 out of 10 nurses start their career at the hospitals or within elderly care (Danish Nursing Association 2008). However, after a while, some seek employment within the private health care sector, mainly as employees at GPs or in jobs unrelated to nursing, such as within teaching or administration. A study from 2008 finds that $19 \%$ of nurses are contemplating getting a job in the private sector. Likewise, $19 \%$ are either to a very high or high degree thinking of leaving nursing to get another job (ibid.). The analysis pays specific attention to retention as a means of mitigating the lack of nurses that existed in 2008 as well as the expected lack of nurses in the future. It finds that $26 \%$ of the vacant positions in the public health care sector in 2008 could be occupied if the movement of nurses could be delayed by one year on average. . As stated in previous sections, however, the worldwide economic crisis impacted the development within the health care sector, and Denmark is not currently experiencing a lack of nurses. In spite of this, some of the regions where most of the nurses find employment are expecting a future lack of nurses, and as will be evident in section 2.3, strategies and initiatives have been and will be initiated in order to attract and retain employees.

An analysis from 2004 shows that $41 \%$ of the newly educated health care workers did not work within elderly care two years after finishing their education (NFA, 2004). Some of these people continue their educa- 
tion and are thus expected to return to the care sector, but the dropout rate is comparatively large. As a consequence, attention has been paid to research on turnover among eldercare staff in recent years. For instance, SOSU-research has been one of the focus areas within the National Centre for Work Environment ${ }^{20}$ since 2003, partly financed by the so-called SATS-pulje. ${ }^{21}$

An issue associated with recruitment and retention of health care workers is the existence of a negative media discourse about the work environment, the fact that the job is a "low status job," the irregular working hours, and the comparatively low salary. Another issue related to the physical tasks for the staff. Despite increased assistance from lifts, etc., the work in the sector involves heavy lifting and un-ergonomic positions. Employees in the elderly care sector are therefore generally more absent / sick (both short-term and long-term) and leave their jobs earlier than any other profession within the public service sector.

\section{Future needs}

The purpose of this section is to give an idea of the future needs within the health care sector by introducing current predictions regarding the overall picture within the health care sector and for the specific professions in question. Before introducing the numbers and figures, however, it is worth taking the limitations of predictions into account.

Predictions such as the ones we have described above in terms of the development of the general workforce and the specific needs within the public sector, drew attention in the beginning of the century. Denmark was expected to face a severe, immediate lack of employees in the health care sector. For instance, one prediction made by FTF and Arbejdernes Erhvervsråd in 2007, showed that the country would lack 5,700 healthand social workers, 5,600 nurses and 2,600 doctors by 2015 (FTF, 2007). However, in the wake of the financial crisis, we have in fact seen rising unemployment within these groups and the predictions are therefore no longer valid.

Some of the most recent predictions and analyses were carried out in 2012.22 They predict the general need for health professionals in

\footnotetext{
20 Det Nationale Forskningscenter for Arbejdsmiljø is anchored in the Ministry of Emplyment. ${ }^{21}$ SATS-puljen represents the money that is annually reserved for special action in the social, health and labor market in order to improve conditions for benefit claimants and vulnerable groups in society. 22 http://www.kl.dk/ImageVaultFiles/id_60800/cf_202/Behovet_for_velf-rdsuddannede_i_Midtjylland070120.PDF, https://fysio.dk/Upload/RA/BehovetforvelfaerdsuddannedeiNordjylland\%202.pdf
} 
2025 in the Northern Denmark and Central Denmark regions based on five different scenarios. The expectations differ therefore depending on the scenario in question. In the Central Denmark Region, none of the scenarios point to a severe lack of employees in general within the relevant health professions. One exemption is nurses, which are expected to be lacking by 2025 in some (but not all) of the scenarios. However, according to the predictions, there will not be lacking doctors, health care workers, ergo-therapists, or physiotherapist in the Central Denmark Region in 2025.

In the Northern Denmark Region, the analysis predicts a quite severe lack of health professionals, specifically nurses and health care workers, in the future. In the Capital Region, however, the analysis predict a surplus of fysiotherapists, ergotherapists, readiographs, health care workers and nurses. An assessment of the future needs have not been made in the remaining two Danish regions, but studies are on their way, indicating that the future needs in the sector is on the agenda in the regions. Danish Regions, the regions' interest organisation, expects that region Zealand and Southern Denmark Region can probably be lumped with the Northern Denmark region. However, as stated above, no predictions have yet been made for these two regions.

\subsubsection{Prominent challenges}

As indicated by the mixed results and predictions put forward in the previous section, we cannot be sure that we will not need health professionals in the future. It is a fact that the Danish population is aging, resulting in a decreasing workforce. At the same time, the demographic development and the overall public health in Denmark is likely to change the overall need in the health care sector and pose new challenges to the health professionals. This section highlights the most prominent challenges within the health care sector, as they look anno 2014.

\section{New elderly}

In 2013, the Home Care Commission, which was commissioned by the Danish Parliament, published their report with recommendations regarding the future care of the elderly (Hjemmehjælpskommissionen, 2013). The Commission states that home care will have to evolve in the future to better correspond with new types of elderly. Many elderly of the future will be healthy, have strong social networks, and sufficient financial means. Many of these elderly will be able to take care of themselves for most of their old age, if not all of it. The Commission, however, describes another group of elderly who will need help in varying de- 
grees. The Commission believes that help-to-self-help and self-care (egenomsorg) will increasingly account for the care for this group. However, the Commission also foresees a group of elderly with severe and complex care requirements, who will have few resources to take care of themselves. The Commission states future expectations of a great increase in the number of citizens with dementia and other chronic ailments along with a growing societal tendency to inequality in health as the main reason for the existence of such a group.

Based on this expected differentiated group of elderly, the Commission suggests a need for a new paradigm in Danish home care, where the capable elderly are encouraged to take care of themselves for as long as possible through help-to-self-help to a larger extend that what is the case today. This means that home care should focus on the underlying health issues that make the elderly unable to take care of themselves rather than on the immediate needs of the elderly, such as house cleaning and personal hygiene. This implies an increased focus on preventive and rehabilitating measures to ensure that as many elderly as possible can lead long, healthy lives with little dependency on help from the public service sector.

The remaining group of weak elderly, burdened with sickness and few resources, with little or no chance of recovering their ability to take care of themselves, will continue to receive home care similar to what is provided in Denmark today.

\section{Elderly's contact with the health sector}

The largest number of health care interactions among the Danish population outside the hospitals are with medical practitioners, and it is a clear tendency that the amount of contact with medical practitioners increases with age (Local Government Denmark, 2010).

When looking at the number of interactions between Danish citizens and health professionals outside the hospital system, such as medical practitioners, medical specialists, dentists, physiotherapists, and chiropractors, the 75-89 year-olds score the highest. In 2010, they frequented a doctor or the like more than 18 times a year. This is more than twice as many interactions as among people aged 15-64. In 2010, 86\% of the Danish population frequented a medical practitioner, and among those aged 90 and older, the number was $98 \%$.

According to the National Authority of Health, elderly people make up $50 \%$ of the somatic patients within the health care sector. In total, the expenditures on patients age 65+ was 24 billion in 2010, while the expenditures related to hospitalization of "the elder medical patient" amounted to $1 / 3$ of this (Local Government Denmark, 2012). 
The elderly medical patient - Den ældre medicinske patient (DEMP)

- Broad definition: "Persons above 65 years of age, who during a specific year has been hospitalised or treated ambulant in a medical department."

- Narrow definition: "Persons above 65 years of age, whose condition is characterised by multimorbidity (more than one illness), decreased functional ability and eventual social insufficiency."

In order to cut down on expenditures related to the activity-based contribution from the municipalities to the regions, the municipalities emphasize the need to strengthen the efforts for this group of patients as well as people with chronic diseases. The aim is to avoid hospitalisation of these groups and treat the patient while he/she is at home (ibid.). At the same time, increased efficiency in the hospital sector means that patients in general are discharged earlier from hospital. As a result, the health care worker is challenged in new ways. It is expected that tasks will be transferred from the regional to the local level, a transfer known as task delegation (Ministry of Health and Prevention et al., 2013). This implies that the skills needed in the local care sector are changing. There will be a lack of competencies and an increased demand for health professionals, who have clinical competencies within the areas of palliative treatment and more demanding tasks not only related to traditional care.

The education to become health care worker has been revised per January $1^{\text {st }}, 2013$ as noted in the tables in section 2.2.3. The abovementioned commission finds that the revision has the right emphasis in relation to the expected future challenges within health care. The employees will need further education to learn how to handle the more complex work in the sector in the future. Alongside this, health care workers must also learn how to adapt to the new work tasks following the above mentioned paradigm shift within the health care sector related to everyday rehabilitation. What is demanded is the capability to handle the larger emphasis on preventive and rehabilitative measures at the expense of more practical work.

\section{Welfare technology and new requirements for home care workers}

It is believed that welfare technology and digital solutions will become increasingly important in the years to come as highlighted in "National Action Plan for the deployment of telemedicine" (Danish Regions et al., 2012). New technology will allow the elderly to take care of themselves longer and lighten the manual workload of the health care worker regarding house cleaning, personal hygiene, etc. New digital solutions will also ease the load of administrative work for the health care worker. 
Taking a gender sensitive approach, it is possible that this shift towards increased use of welfare technology could attract more men to the health care sector in the future. Thus, according to the scientist Simon Baron-Cohen, technology and "systemizing" is generally believed to appeal more to men than women, who are believed to be more "empathetic" than men. ${ }^{23}$

\subsection{Strategies}

\subsubsection{Shared perception of challenges}

This section highlights the general trends and patterns as they appear in the various documents and as presented by informants in qualitative interviews.

The following sections focus on the overall strategies and centrally initiated initiatives. One of the informants describes the policies for retaining employees as "heart-blood" for the municipalities, indicating that many concrete initiatives take place in the 98 Danish municipalities. This is also the case at the regional level. In the following sections the central actors in Denmark and their strategies are described, that is the Ministry of Health and Prevention, Danish Regions, Local Government Denmark (both employers' organizations), and FOA (the professional organisation for the Danish health care workers).

\section{Ministry of Health and Prevention}

The changed demography with more elderly and the following increase in demand for welfare services is one of the foci within the Ministry of Health and Prevention (MHP). The understanding is that the rising demand after health care services and health professionals is hard to satisfy, and does require changed ways of working in the health care sector as a whole and new competencies among the staff. According to MHP, this is especially true for the health care professionals in the municipalities, who will often meet weaker and sicker citizens as described in section 2.2.4. This makes demands of the employees' general skills and ability to work interdisciplinarily. An evaluation of the Local Government

${ }^{23}$ For instance: Autism: The Empathizing-Systemizing (E-S) Theory, Annals of the New York Academy of Sciences, Volume 1156, The Year in Cognitive Neuroscience 2009 pages 68-80, March 2009. 
reform, carried out in 2012, shows that there are challenges concerning the overall vision of MHP, which is to create a coherent health care sector in Denmark. These challenges are specifically related to the cooperation between the municipalities and the regions following the changed division of responsibilities for services following the Local Government reform of 2007.

Thus, the strategies and initiatives regarding recruiting and retaining are embedded in an agenda focusing on quality and coherency in the health care sector. As a result, the Danish strategies and initiatives are not primarily focusing on meeting a specific quantitative need. The interviewee from MHP notices the fact that it is very hard to make predictions, especially within the health care system, because the development of the sector happens fast and the demand for health services can change rapidly. Predictions are important, but other trends in the health care sector must be taken into account when planning the strategic approach to the future. Thus, the overall strategy aims to mitigate the challenges surrounding an ever-changing sector by focusing on continuing education, flexibility, and delegation of tasks between the health professionals and administrative levels.

In the wake of the public bargaining in 2007, the MHP took lead on establishing a taskforce aiming to strengthen actions related to promoting flexibility, task delegation, and more appropriate planning of tasks within the health care sector. The taskforce was composed of several organisations; the Ministry of Interior and Health (former MHP), Local Government Denmark, Danish Regions, Danish Nursing Association, FOA, Danish Medical Association, and DL Patient/Administration/Communication (organised within the professional organization HK/Danmark). These organisations agreed on the fact that flexible task performance and delegation of tasks between health professionals are important tools in order to secure the best possible use of the competencies and resources within the health care sector. A successful implementation of this overall goal would make it possible to deliver services of high quality and security for the elderly and the patients. In 2007, the aim was also to mitigate the expected lack of health professionals. However, this part of the agenda is no longer a high priority today where the predictions regarding the specific need for health professionals in Denmark are ambiguous as described above. Thus, the focus on quality and security for the patient within the sector is prominent from the central political perspective. The taskforce culminated in a catalogue of inspiration with 20 concrete suggestions and examples of flexible task performance, which the municipalities and regions could take as a starting point. 
In spring 2013, MHP presented a policy paper, which addresses the prominent challenges in the health care sector anno 2013.Althoughhe document has a broad focus, many of the challenges relate to the skills and competencies of the health professionals with the aforementioned common denominator of enhanced coherency and quality in the health care sector as a focal point. For instance, the Danish government wishes to strengthen professional competencies in local nursing by systematically improving the possibilities for relying on the skills of general practices and hospitals. An example could be by creating permanent consultancy functions at hospitals. The government has leveraged funds specifically to improve and strengthen the competencies of the front personnel in the municipalities, mainly health care workers and therapists (physio- and ergotherapists). In addition, specific attention is being paid to the possibilities within telemedicine, health-IT, and digitalization. The reasoning behind this focus on digitalization is not just related to the lack of personnel. Rather, the demographic challenges, the economic situation, and the limited possibilities of raising public spending are mentioned as main tendencies pushing the need for development and distribution of telemedical solutions. ${ }^{24}$ While a telemedical process has shown to improve the course of an illness for the citizen, the potential related to the need of man-power (and lack of financial resources) is certainly also realized within the MHP.

\section{Danish Regions}

Danish Regions are responsible for the hospitals, and their strategies therefore relate to the functioning and development of hospitals in Denmark. As indicated in the previous section on the Ministry of Health and Prevention, an important part of the strategic work within the health care sector in general is the transfer of task between the health professionals and administrative levels. This is also the case at the hospitals. It is important to remember that the expected future shortage of health professionals varies between the five Danish Regions as explained in section 2.2.3.

In 2008, Danish Regions launched a competition with the title "How to secure the health care sector enough qualified workers". The wording "enough qualified" indicates that both quantitative and qualitative aspects of the challenges and needs of the future health professionals are

${ }^{24} \mathrm{http} / / /$ www.digst.dk/Digital-velfaerd/ /media/Files/Velf\%C3\%A6rdsteknologi/

Telemedicinsk\%20handlingsplan/Telemedicinsk\%20handlingsplan-web.pdf 
important to the organisation. However, it is fair to say that the qualitative view has been the most prominent in recent years, at least from a central perspective.

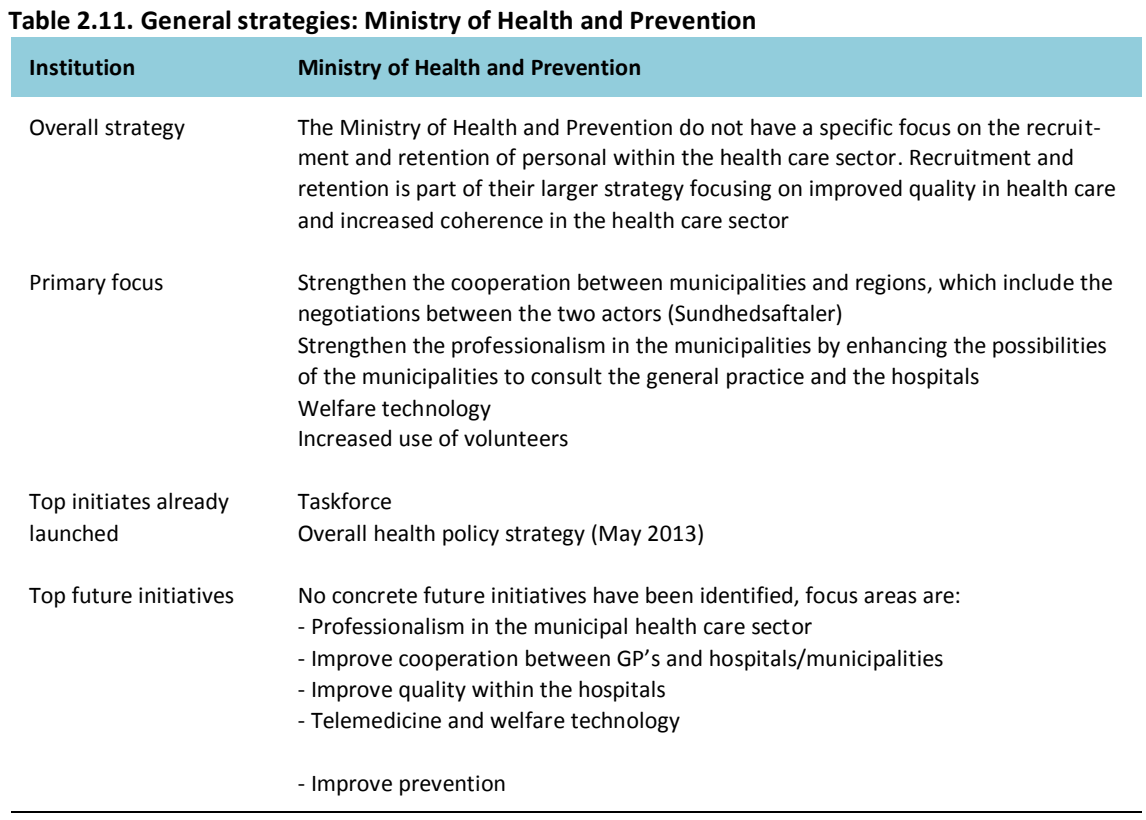

Source: Interviews.

Back in 2009, Danish Regions, Local Government Denmark, FTF, and University Colleges Denmark launched "Strategy for the welfare educations". The purpose of this strategy was to focus on how to increase the number of applicants to the welfare educations, improve the completion rates, and the quality of the educations in general. Specific attention was paid to the coherence between theory and practice, which is still an area of importance within the development of the basic educations. In 2012, the strategy "Quality within the future health educations" was presented. The presentation provided recommendations cantered around the needs within the somatic and the psychiatric hospital sectors, and aimed at qualifying the education by providing guidelines related to the content, organisation, and dimensioning of health professions in Denmark. It thus highlighted both quantitative and qualitative perspective of the future need of health professionals.

Continuing education also plays a vital role within the Danish hospital sector, where mainly doctors and nurses are employed. Due to the shortening of patients' hospital stays, the group of health care workers (with and without authorisation to hand out medication) at the hospitals is declining. At the hospitals, "new" educations have been developed in 
order to adjust to the future requirements and to make better use of the competencies of the health care staff. For instance, starting in 2014, nurses will be educated and trained in order to be able to perform intestine screenings. An important feature of these new educations is that they take the "clinic" as their point of departure point and have a very practical foundation. This is important in order to meet the needs of the hospital sector. Sfrom the perspective of Danish Regions, some of the postgraduate programs, e.g. within nursing, have a tendency to "educate the nurses out of the clinic and place them behind a desk." For instance, Diploma educations focusing on health promotion, communication, or quality improvement do not really have the potential of retaining staff in the health care sector, as it is very hard to implement their acquired skills on a daily basis at the hospital. In the cooperation forums where the development of the educations are discussed, Danish Regions has pushed for the possibility of taking modules at the hospitals as a part of the continuing education. However, from a central point of view within the Ministry of Research, Innovation and Higher Education, this is believed to be a slippery slope that might decrease the quality of postgraduate programs. Thus, the regions work strategically with, and calls for more cooperation between, Danish Regions and the suppliers of the educations, especially within continuing education.

Another strategic commitment, which cannot be categorized as aiming to recruit or retain, is "policy on full-time", which has come into effect January 1st 2014.25 The policy aims to make better use of the competencies at the hospitals by stating that all vacancies within the five regions must be posted as full-time positions only. The aim is that $80 \%$ of the employees at the regional workplaces will be working full time in 2021. The policy was adopted in order to meet the needs at the hospitals. According to an analysis carried out by Aarhus University in 2011, $1 / 3$ of the employees at the hospitals are working part-time. ${ }^{26}$ Thus, there is a big potential in increasing the number of employees working full-time. However, Danish Regions acknowledges that Denmark generally is going to need people in the workforce in the years to come. Since most of the growth is created in the private sector, Denmark cannot afford the welfare loss created when too many employees work part-time.

\footnotetext{
25 http://www.regioner.dk/ /media/Mediebibliotek_2011/ARBEJDSGIVER/Arbejds-

$\% 20$ og\%20ans\%C3\%A6ttelsesret/Politik\%20om\%20fuldtid_2013.ashx

${ }^{26} \mathrm{http}: / /$ www.regioner.dk/ /media/L\%C3\%B8noverenskomster\%20og\%20Ans\%C3\%A6ttelsesvilk\%

C3\%A5r/Publikationer/Rapportens\%20sammenfatning.ashx
} 


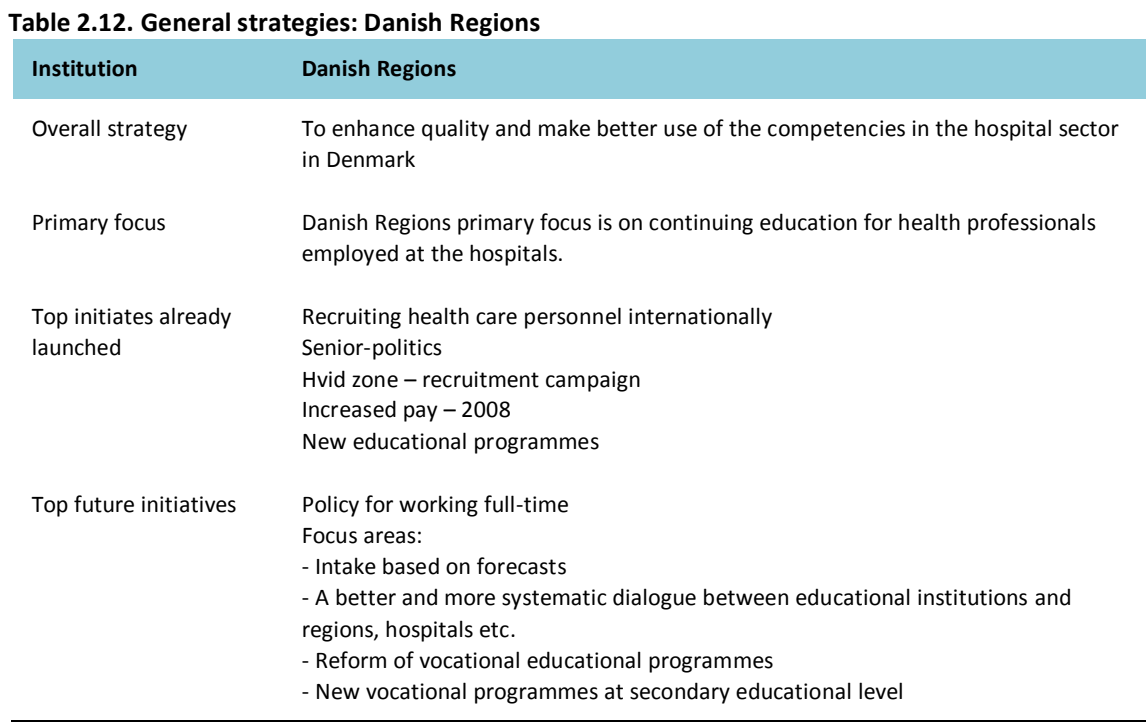

Source: Interviews.

\section{Local Government Denmark}

Local Government Denmark is the representative of the 98 municipalities in Denmark. As described in section 2.1, the reform in 2007 gave the municipalities a strengthened role in the Danish health care service. This means that there is a change in the competencies needed among the health professionals in the municipalities.

Up until the financial crisis, expenditures on health care and the number of employees within the health care sector at a local level were increasing. With the collective bargaining in 2008 , a general pay rise was given, and it was decided that adults with at least one year of relevant work experience should be offered a higher salary (voksenelevløn). Since then, however, Local Government Denmark has not been focusing on recruitment and retention of personnel within the health care sector in the municipalities. Firstly, according to Local Government Denmark, most municipalities are not currently experiencing recruitment problems. Secondly, recruitment and retention is part of the organization's larger strategy for improving quality in health care and increasing focus on prevention and rehabilitation. A central aim is to establish uniformity across the municipalities, relating to standardising and documentation in home nursing and home care. In cooperation with the Danish Medical Authorities, Local Government Denmark works to gain more knowledge on what works in the municipalities and creating evidence. 
Whereas the number of employees is not a major concern, the educational level and skills among the employees is. Over the past years, the municipalities have increased the number of employees who receive continuing education focusing on learning by doing, using simulationtraining, and gaining insight in to telemedicine and welfare technologies. Moreover, the front personnel in the municipalities must be able to carry out the action of documentation, with evidence in the health care sector being a prominent priority. As a concrete example, the Danish Medicine Authority has developed a tool for early tracing of the elderly medical patient, which has been implemented in the municipalities.

A very important part of retaining health care personnel in the municipalities has to do with establishing good working conditions. In this regard, sick absenteeism is a challenge, which has been accentuated by the economic trends and the focus on quality. While sick absenteeism has traditionally been quite high within the care sector in the municipalities, there is a risk that the number of sick days will rise with the new division of labour because it is hard for employees to meet the changing demands related to professional and personal development. A common denominator among initiatives in the municipalities is the believe that it is the responsibility of the management to decrease sickness absenteeism. Each municipality therefore has policies related to absenteeism and retention.

Another key trend among the 98 municipalities, and within Danish society in general, is the use of volunteers in the provision of welfare services, which has traditionally been managed by paid personnel. Volunteers typically engage in the softer areas of care, such as walking or reading with the elderly at nursing homes or in their homes. While some volunteers are organized through organizations, such as Red Cross Denmark, an increasing number is organized directly at the nursing homes, with a public employee as their leader. This is called "Communal volunteerism". A group of volunteers that is of specific importance within the health care sector is relatives. Today, this group is involved in the care of sick and elderly at both hospitals and at nursing homes to a larger degree than before. 


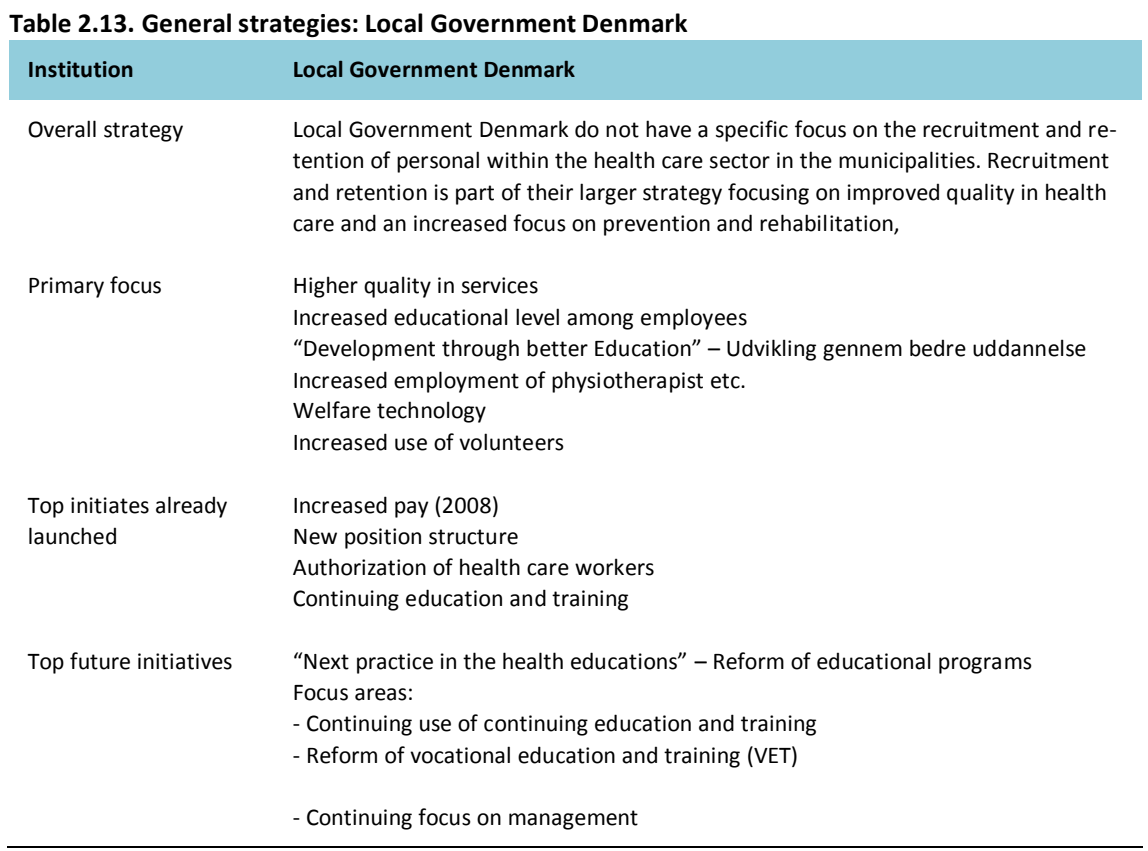

Source: Interviews

\section{FOA}

FOA is a professional organisation organizing health care workers (with and without authorisation). FOA differs from the other organisations in this section, as the organisation represent employees and thus different interests compared to the Ministry of Health and Prevention, Danish Regions, and the Local Government Denmark. However, it is worth noting, that FOA was part of the taskforce aiming at strengthening the flexibility and transfer of tasks within the health care sector, introduced in the section about the Ministry's strategy. Thus, it is important not to overestimate the differences between the informants in this section. In general, a large degree of consensus regarding challenges and solutions can be identified.

Within FOA, the changing demand for competencies for the health care workers is high on the agenda. This has to do with the fact that the number of health care workers without authorisation (SOSU-helpers) has been cut down drastically in both regions and municipalities, because of the increased demand for staff with knowledge about dementia, chronic diseases, and wounds, which are important competencies within home nursing. Thus, continuing education of the health care workers is regarded as very important. Continued education takes place under the auspices of AMU, and offer health care workers a variety of courses, such as "Cooperating with volunteers in the welfare work", "Dementia", "postoperative treatments", etc. 


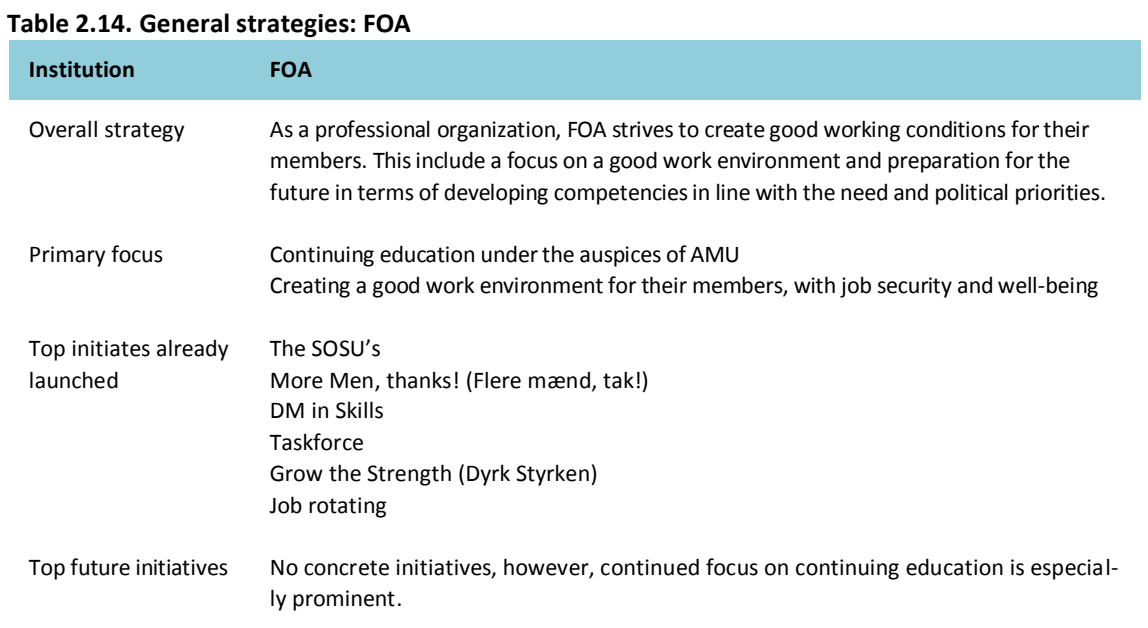

Source: Interviews

As part of the increased focus on continuing education, a model of "job rotation" has been implemented in recent years. The concept comes in different varieties, and a range of different projects are taking place at the moment. Basically, the idea is that while some staff members are upgrading their skills and competencies, unemployed substitutes take over and are thus educating themselves at the same time. Job rotation is an effective tool in providing both more and "better" hands to the municipalities. Job rotation ensures education for those who are currently employed with no or little training, while at the same time allowing for new people and potential staff to enter the health care sector. Job rotation does not require funding by the municipalities and does not burden the institutions' budgets. Employees receive full pay during training, and the temporary worker receive full salaries that are determined in the collective bargains. This method is an instrument used in the effort of labour market policies in general, and thus not solely related to the health care sector.

With regards to retention, sick absenteeism is very high on the agenda, and it is a core strategy within FOA to work strategically with reducing sick absenteeism. One of the themes on the yearly conference in FOA was the link between professionalism and a good work environment. The rationale behind this link is the idea that when a health care worker carries out a lift correctly, it is not only good for his/her back, , but also strengthenshis/her professionalism and skill. As such, it increases the probability of the health care worker staying longer in his or her job. The concrete initiatives with regards to reducing sickness absenteeism are carried out in each of the 98 municipalities as discussed in the introduction to this section. 


\subsubsection{Initiatives - an overview}

In the previous section, the organisations' strategies were presented, along with examples of centrally initiated initiatives. This sections zeroes in on the initiatives with an aim to categorise and analyse them. Through the analysis, we can gain useful information concerning the potential of different initiatives, and maybe even shed light on areas where little or no initiatives have yet been taken.

In general, the challenge of recruitment and retention of personnel in the health care sector can be addressed at two levels: an educational level and a work place level. This is indicated in table 2.15 below, where the concrete Danish initiatives are listed.

\begin{tabular}{|c|c|c|c|c|}
\hline & \multicolumn{2}{|c|}{ Education } & \multicolumn{2}{|c|}{ Workplace } \\
\hline & Recruitment & Retention & Recruitment & Retention \\
\hline $\begin{array}{l}\text { Examples of } \\
\text { initiatives }\end{array}$ & $\begin{array}{l}\text { Campaigns } \\
\text { Increased intake } \\
\text { New educational } \\
\text { pro-grammes }\end{array}$ & $\begin{array}{l}\text { Mentoring pro- } \\
\text { grammes } \\
\text { Reforms }\end{array}$ & $\begin{array}{l}\text { Attracting foreign } \\
\text { health care } \\
\text { person-nel, } \\
\text { Campaigns }\end{array}$ & $\begin{array}{l}\text { Conditions of employment } \\
\text { Work/life balance } \\
\text { Working environment } \\
\text { Continuing education and } \\
\text { training } \\
\text { Management } \\
\text { Talent Management }\end{array}$ \\
\hline Denmark & $\begin{array}{l}\text { "White Zone" - } \\
\text { Reform of educa- } \\
\text { tional programmes } \\
\text { - DM in Skills, "the } \\
\text { SOSU's" - Universi- } \\
\text { ty College Reform }\end{array}$ & $\begin{array}{l}\text { University College } \\
\text { reform, reform of } \\
\text { educational } \\
\text { programmes }\end{array}$ & $\begin{array}{l}\text { "More Men, } \\
\text { thanks" - policy } \\
\text { on full time }\end{array}$ & $\begin{array}{l}\text { New educational pro- } \\
\text { grammes based in the } \\
\text { clinic - "More Men, } \\
\text { thanks" - policy on full } \\
\text { time }\end{array}$ \\
\hline
\end{tabular}

\section{Recruiting and retaining within the educational sector}

As evident from section 2.3.1 above, the strategic response to the future needs of the health care sector by the central actors in Denmark has both quantitative and qualitative aspects. For instance, the reforms of educational programmes underway is first and foremost focused on improving the basic educations within the health care sector, thus creating coherence between the different administrative levels in the Danish health care sector.

However, more "traditional" recruitment campaigns have also been launched, for instance "White Zone" (Hvid Zone, 2009-12), which proved very successful in increasing the number of applicants within the three educations studied (nursing is the only relevant field here). The campaign focused on social media and highlighted the need for courage and vigour in order to become a successful health professional (nurse, radiograph and bioanalyst). The campaign paid separate attention to gender, 
with the website linking to a website called "men are also nurses" (mandligesygeplejersker.dk). Quite a few such gender focused initiatives have been initiated in Denmark. "White zone" was launched in 2009 by ministries, university colleges, Danish Regions, and the professional organisations, and was intended to run as a 3-year campaign. However, in 2012 and 2013 it was continued by the professional organisations and the University Colleges.

Another example of traditional recruiting campaigns is the campaign "The SOSU's", with the longer title "Gain knowledge on reality", which was launched in 2010. The campaign was aiming to recruit applicants for positions as SOSU-helpers and SOSU-assistants. At that time, the financial crisis was going strong, and staff was being fired in the municipalities. However, the understanding at that time in FOA and Local Government Denmark, who initiated the campaign, was that there would be a great need of health care workers in the future.

A range of national actors (e.g. FOA) are aiming to make vocational educations, such as health worker, more popular. The aim of the arrangement is to shed a positive light on vocational training, which has a quite bad reputation because of the prospects of a low salary, among other things. "DM in Skills" is a highly profiled project in which more than 40 vocational educations are represented as either competitors or demonstrators. The hope is to use this yearly arrangement to improve the image and attract qualified students to the vocational educations in Denmark.

As indicated above, gender issues have received quite a lot of attention in Danish recruiting campaigns. For instance, the campaign site "change job, not gender" (Skift job, ikke køn) was launched following the Danish Presidency of the Nordic Council of Ministers in 2010. The project focused on the group of primarily unskilled men, who lost their job in the wake if the financial crisis. ${ }^{27}$ The Nordic labour markets are generally very gender segregated, which results in reduced flexibility and bottlenecks. The aim of the project was to encourage men to make a career shift by highlighting the potential within the public sector, especially within elderly care and nursing. The website entailed cases and a toolbox ofgood practices regarding the recruitment of men. These recommendation were partly based on the anthology "Nordic men to care work" (Nordiske mænd til omsorg-

${ }^{27}$ Quite a lot of initiatives focus on gender and recruiting men to the traditional woman-educations in the health care sector. Other examples are MPower, (http://www.mpowermen2men.dk/), Factor 2007, SOSU takes a man (SOSU kræver sin mand). 
sarbejde, 2010), which mapped and analysed all the Nordic countries' initiatives aiming to recruit more men to typical "women's professions" in the public sector. Thus, the recruitment of men to welfare professions has received attention in a Nordic context.

Institutional reforms have also been implemented in order to enhance quality within the Danish educational system. In 2007, University Colleges and Business Academies were established. The aim of the reform was, among other things, to strengthen professional competencies and create attractive study environments, with the potential to recruit and retain students. At the University Colleges, research has been strengthened, exemplified by the fact that the Danish Government leveraged funds for the University Colleges to focus heavily on research and development. The University Colleges' aim to qualify $50 \%$ of their teachers to $\mathrm{PhD}$ level within the next 10 years.

As evident from the section above, the division between recruiting and retaining in the educational sector is not clear-cut. A lot of the work carried out with regards to improving quality of the educations is obviously also aiming at retaining the students. For instance, a large effort is put into strengthening the link between theory and practice in order to minimise the risk of a "practice shock" and thus retaining students at the health professions. Research within the area of health care workers shows that the students' reasons for dropping out are very often related to their experiences during their practice in the municipalities.

\section{Recruiting and retaining at the work place}

Gender aspects are also evident within the workplaces, for instance with the 2009 campaign "More men, thanks!" (Flere mænd, tak!) aiming at both recruiting to and retaining men in the care sector in the municipalities. The campaign was co-financed with Local Government Denmark and "Kommunale Tjenestemænd og Overenskomstansatte" (KTO). The project highlighted the need to attract more men to the same workplace, creating male network-groups across different work places, and the establishinga male culture in which the competencies of men are appreciated, among others. This is only one of many initiatives aiming to attract men to the health professions. The widespread focus on continuing education is also aims at retaining personnel at the hospitals and in the municipalities. However, as highlighted in the analyses of the strategies of the central political actors above, concrete initiatives aimed at recruiting and retaining at the workplace have been scarcer. 


\subsubsection{Concluding remarks}

As evident from section 2.2, the challenges in Denmark are multifaceted. The challenges related to a shortage of health professionals in the future are not clear-cut, and it is important to take geography into account. Thus, while a future need of health professionals is foreseen in the Northern Denmark region, results are more mixed in the Central Denmark Region, and not yet thoroughly analysed in the remaining three Danish regions.

However, other challenges are evident, as a rising number of elderly and a decreasing workforce in combination with economic constraints pose serious challenges to the Danish health care sector. This is reflected in the strategies and perspectives from the central political actors. The description above point to the fact that coherence and quality of the future health care sectors are high priorities on the agenda. However, as evident from the various recruitment campaigns launched in Denmark, the number of future health professionals is also important. 


\section{Appendix 2: Finland}

\subsection{Framework conditions}

\subsubsection{Judicial structure and organization}

In Finland, the state's responsibility to promote welfare, health, and security is rooted in the Constitution (The Constitution of Finland 731/1999), which enshrines the right of everyone to income and care if they are unable to manage their lives adequately.

The duties of the municipal authorities throughout Finland to manage social and health care are stipulated by special legislation. Laws on health care, primary health care, and specialised medical care, cover health services (Health Care Act 1326/2010, Primary Health Care Act 66/1972, Act on Specialised Medical Care 1062/1989). There are separate laws on occupational health care, mental health services, the prevention and treatment of infectious diseases, and the status and rights of patients (Occupational Health Care Act 1383/2001, Mental Health Act $1116 / 1990$, Communicable Diseases Decree 786/1986, Act on the Status and Rights of Patients 785/1992). Legislation also covers the professional standards of health care personnel (Act on Health Care Professionals 559/1994).

\section{The service system}

Everyone in Finland is entitled to adequate social and health services. The aim of health care is to maintain and improve people's health, wellbeing, work and functional capacity, and social security, as well as to reduce health inequalities.

Municipal services, implemented with government support, form the basis of the social welfare and health care system. Municipalities can provide basic social welfare and health care services alone, or form joint municipal authorities with other municipalities. Municipalities may also purchase social welfare and health care services from other municipalities, organisations, or private service providers. Private health care services supplement municipal services. In addition, a wide range of social welfare and health care organisations provide services. 
The municipalities are responsible for arranging and funding comprehensive social welfare and health services. Health services are divided into primary health care and specialised medical care. Primary health care services are provided at municipal health centres. Hospital districts organise specialised medical care.

The Ministry of Social Affairs and Health prepares legislation and guides its implementation, directs and guides the development of social welfare and health care services, as well as defines social welfare and health care policy guidelines, prepares key reforms, and guides their implementation and coordination. National Supervisory Authority for Welfare and Health, Valvira, under the Ministry's administrative branch guides, monitors, and manages the administration of the licences for the social welfare and healthcare sector, alcohol administration, and environmental health and protection. Regional State Administrative Agencies guide and monitor municipal and private social welfare and health care services and evaluate the availability and quality of basic services provided by municipalities. They also grant licences to private service providers in the region and supervise health care professionals in collaboration with Valvira. Furthermore, there are agencies and institutes in charge of research and development under the Ministry's administrative branch (e.g. National Institute for Health and Welfare, Finnish Medicines Agency, Fimea, Finnish Institute of Occupational Health).

\section{Local government reform under preparation}

At the moment, a local government reform is being prepared. As a part of the local government reform, the Ministry of Social Affairs and Health's working group is preparing a reform of the social welfare and health care service structure. The aim is to reorganize the services on a broader population base and in greater entities than at present in order to ensure that the population can obtain equitable services of a high quality.

The future local government structure will be of crucial importance in determining how many social welfare and health care regions formed by municipalities will be needed in addition to the strong municipalities. The present hospital districts will be combined into five specific catchment areas responsible for the coordination of certain centralized services and services in the areas.

The act on the provision, funding, development, and supervision of social welfare and health care is planned to come into force in 2015. The new service structure will be implemented and the mergers of municipalities will be realized, depending on the scope of the change, in 2015/2017. 


\subsubsection{Financing}

The main component of the Finnish health care system is the municipal health services. From a financial point of view, there are two other important parts: private health services and occupational health care. In 2011, health expenditure in Finland as a proportion of GDP was 9.0 per cent. This is 3,165 euro per capita. In 2012, health expenditure is estimated to have reached 9.5 per cent of GDP.

The state, municipalities, and clients finance the municipal health services. The main source of revenue is the municipal taxation, covering approximately two thirds of the expenditure. The state finance of municipal health care occurs to a large extent in the form of state grants collected with state taxation. The size of state grant per municipality depends on several factors such as the municipality's own revenue-raising capacity and demographic and morbidity indicators. The state grants are not ear-marked to health care specifically - they are for social care and educational services as well. On average, the state finance covers approximately $30 \%$ of the municipal health care costs. Out-of-pocket payments cover some $5 \%$ of the costs. The municipal health services are complemented by the private-sector services, which are mainly of outpatient nature. The compulsory and universal National Health Insurance (NHI) partly reimburses the costs of private services. On average, the reimbursement rates are quite low, ranging around 25-35\% The NHI scheme is financed in equal amounts by state taxation and by compulsory contributions from the insured. It is managed by the Social Insurance Institution. The reimbursements for outpatient pharmaceutical expenditure and travelling costs are financed through $\mathrm{NHI}$ as well.

In Finland, employers are required by law to provide preventive occupational health services to their employees. In addition, employers can choose to offer access to medical care at the primary care level. Employers are entitled to a reimbursement of the necessary and reasonable costs of arranging occupational health services. Depending on the type of services, up to $60-50 \%$ of the total costs approved by the Social Insurance Institution are reimbursable. The reimbursements are financed with insurance contributions from the employers and the employees. The rest of the costs are borne directly by the employers. The services are free of charge to the clients. 


\subsubsection{Human resources in social and health care}

More than a quarter of all employed women in Finland (28.2\%) worked in the social welfare and health care sector in 2010. The figure grew by 2.8 percentage points between 2000 and 2010 .

At the end of 2010, the social welfare and health care sector employed a total of 372,300 people, of whom approximately three quarters (approximately $74 \%$ ) worked in the public sector. Approximately $16 \%$ worked in private enterprises and just over $10 \%$ in non-governmental organisations. There were 3,0 practising physicians and totally 9,6 nurses, public health nurses and midwifes per 1000 population in 2010. These figures are roughly the average level of OECD countries.

The social welfare and health care sector is extremely femaledominated. In 2010, men accounted for only $11.6 \%$ of personnel. The percentage hardly changed during the 2000s. The average age of personnel was approximately 43.5 years in 2010. Just over one in five will reach the age of 65 by 2020 .

The emigration of Finnish working-age health care professionals decreased considerably between 2000 and 2012. Although migration rates are quite low, there were approximately three times more Finnish nurses residing abroad than foreign nationals working as nurses in Finland in 2010. There were fewer Finnish doctors residing abroad than there were foreign doctors in Finland.

The number of social welfare and health care service personnel with foreign background in Finland increased between 2000 and 2010. Although the increase was relatively substantial in those years, the percentage of social welfare and health care service personnel with foreign backgrounds was still low. At the end of 2010, foreign nationals accounted for just over $1.5 \%$ and people of not Finnish origin for 3.5\% of all social welfare and health care service personnel. Of different social welfare and health care professions, the percentage of foreign nationals was higher than average among doctors, dentists, and assistants. The percentage of foreign nationals among nurses and practical nurses was considerably lower. The physicians mainly come from Estonia and Russia, and nurses commute to Sweden and Norway, as well to other EU countries. 


\subsection{Challenges}

\subsubsection{Demographic challenges}

According to Statistics Finland (www.tilastokeskus.fi), Finland's population was 5,448,025 at the end of October 2013. The main reason for the population increase was migration gain from abroad. In total, there were 279,616 persons with foreign origin living permanently in Finland at the end of 2012 , which is $5.2 \%$ of the population. Nearly every tenth of the persons aged 25 to 34 living permanently in Finland were of foreign origin. In the Greater Helsinki region, the corresponding proportion was nearly one-fifth.

The majority of the Finnish population is concentrated around urban settlements. Nearly $85 \%$ of Finns lived in urban settlements at the end of 2012. The majority of the urban settlements are small. There were six urban settlements with more than 100,000 inhabitants in Finland. The largest urban settlement is the Helsinki central locality with over 1.2 million inhabitants and stretching over the area of 11 municipalities.

The proportion of persons aged 65 or over is estimated to rise from the present $18 \%$ to $26 \%$ by 2030 , and to $28 \%$ by 2060 . The predictions shows that the number of working-age persons will slowly start to increase after that. The proportion of people of working age will decrease from the present $65 \%$ to $58 \%$ by 2030 and to $57 \%$ by 2060 . In 2060 , the number of people of working age would be nearly the same as at present, but the proportion would be nine percentage points lower than now. Table 3.1 includes population projections by age groups by 2040 .

The demographic dependency ratio (the number of children and pensioners per one hundred persons of working age) will go up in the near future (figure 3.2). At the end of 2011, the demographic dependency ratio was 52.9. The limit of 60 dependents would be reached in 2017 and that of 70 by 2028. In 2060, the demographic dependency ratio would be 77 . 
Figure 3.2. Demographic dependency ratio in 1950-2012 and projection for 2013-2050

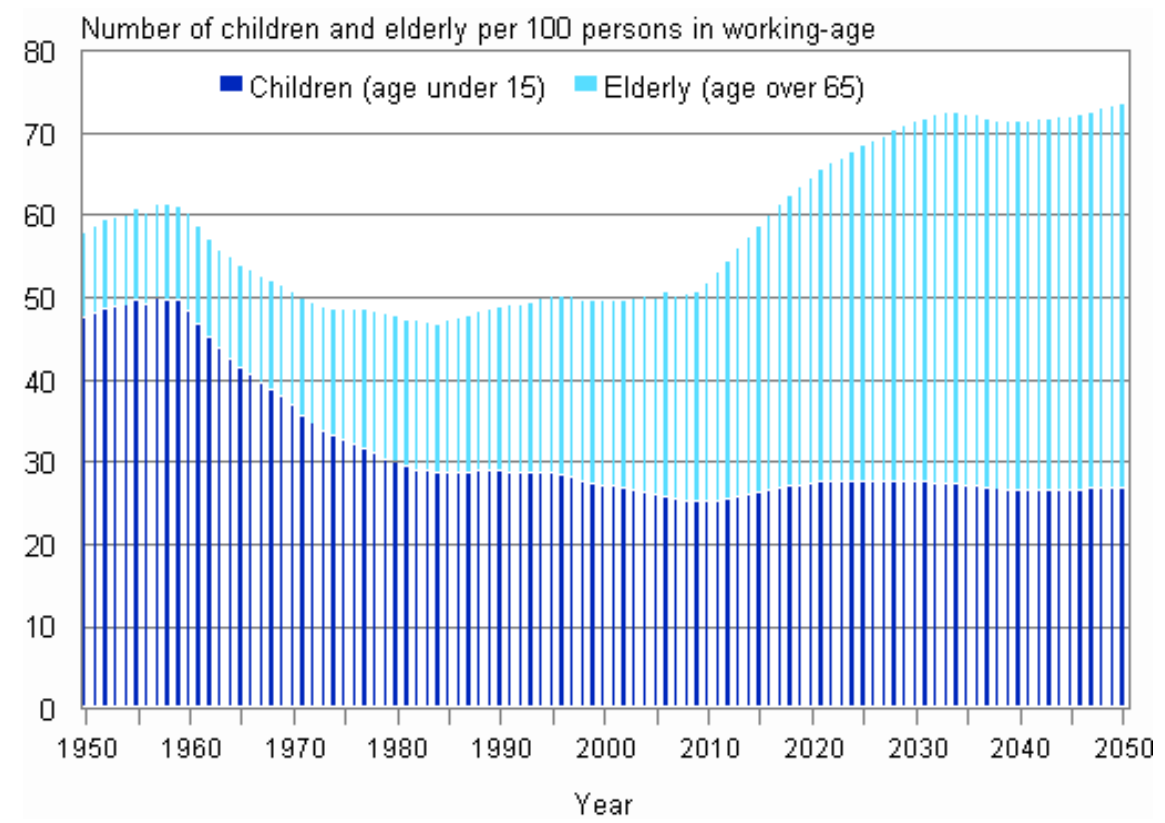

Source: http://www.tilastokeskus.fi/til/vaerak/2012/01/vaerak_2012_01_2013-09-27_kuv_006_en.html

\begin{tabular}{|c|c|c|c|c|c|c|c|c|}
\hline \multirow[b]{2}{*}{ Age cohort } & \multicolumn{2}{|c|}{2020} & \multicolumn{2}{|c|}{2030} & \multicolumn{2}{|c|}{2040} & \multicolumn{2}{|c|}{2060} \\
\hline & Total & Pct. & Total & Pct. & Total & Pct. & Total & Pct. \\
\hline $0-14$ & 932,596 & 16.6 & 936,712 & 16.0 & 923,027 & 15.4 & 948,631 & 15.2 \\
\hline $15-64$ & $3,425,603$ & 60.8 & $3,415,342$ & 58.4 & $3,495,360$ & 58.4 & $3,523,775$ & 56.6 \\
\hline $65-74$ & 714,898 & 12.7 & 675,865 & 11.6 & 618,594 & 10.3 & 710,365 & 11.4 \\
\hline $75-84$ & 400,825 & 7.1 & 593,758 & 10.2 & 587,551 & 9.8 & 622,861 & 10.0 \\
\hline $85-94$ & 145,381 & 2.6 & 208,378 & 3.6 & 329,490 & 5.5 & 357,796 & 5.7 \\
\hline $95+$ & 11,714 & 0.2 & 17,623 & 0.3 & 30,876 & 0.5 & 64,207 & 1.0 \\
\hline All & $5,631,017$ & 100 & $5,847,678$ & 100 & $5,984,898$ & 100 & $6,227,635$ & 100 \\
\hline
\end{tabular}

Source: www.sotkanet.fi

\subsubsection{The Finnish workforce and unemployment}

Long term forecasts on workforce demand and corresponding forecasts on educational needs have been carried out in Finland every four years since 1991. The goal of the workforce predictions and planning is to achieve a better balance between the supply of education and training and the workforce demand as well as to support decision-making on education and training. A key objective of education policy is to provide all young people (the average 16-21 age group for a certain period of time) an opportunity to apply for professional and vocational education 
and training. This approach aims to ensure that young people entering education and training will be divided into educational fields in accordance with the anticipated workforce demand in different industries.

Entrant targets for professional and vocational education and training are adopted by the Government every four years as a part of the development plan for education and university research. The preparation of the development plan for education and university research is regulated by legislation (Decree on the Development Plan for Education and University Research 987/1998). The development plan defines targets for educational supply within the next five years as entrant targets and output of qualifications for every field and level of professional and vocational education and training. Intake in universities, polytechnics and vocational institutions is defined in accordance with the national entrant targets.

\subsubsection{Structures for workforce forecasting and planning}

Long-term forecasts on workforce demand are produced by the Government Institute for Economic Research (under the Ministry of Finance) and commissioned by a collaborative group of four ministries. They are the Ministry of Employment and the Economy, the Ministry of Finance, the Ministry of Education and Culture and the Ministry of Social Affairs and Health.

Forecasts on educational needs and proposals on entrant targets are produced by the Finnish National Board of Education (under the Ministry of Education and Culture) on the basis of the forecasts on workforce demand. The Ministry of Education and Culture appoints a wide group of experts to steer and provide expertise of different industries for forecasting educational needs. These experts present e.g. the Ministry of Social Affairs and Health, the Local Government Employers, trade unions, regional authorities and other stakeholders.

Workforce anticipation and planning takes place also at the regional level. Regional councils have a statutory responsibility (Act 1651/2009) to coordinate the regional preparation of the long-term and mediumterm forecasts for educational needs as a part of the preparation of the development plan of education and university research. Since 2011, primary health care units in hospital districts have had a statutory responsibility to ensure adequate human resources and the hospital districts within a catchment area for highly specialised medical care to participate in regional collaboration regarding workforce forecasting managed by the regional councils (Health Care Act 1326/2010). The local authorities forming the joint municipal authority for a hospital district 
have to ensure the availability of the personnel in primary health care through a health care provision plan which must be provided on the basis of the health statistics and the needs of the population (See Decree $337 / 2011$ ).

\subsubsection{Forecasts on workforce demand}

The current long term forecasts on workforce demand covers years from 2008 to 2025. The general workforce planning process covers all 28 industries, of which health care is one. The workforce demand projections of the Government Institute of Economic Research are provided into three different scenarios. According to the target scenario on average about every fifth new job will be opened in health and social work during the next 15 years.

\subsubsection{Forecasts on educational needs}

The Finnish National Board of Education has provided forecasts on educational needs and corresponding entrant targets for 2011-2016 on the basis of the forecasts on workforce demand. Table 3.3 describes the entrant targets for young people by 2016 . The intake in social services, health and sports should be increased by $7 \%$ compared to the average change of $-5 \%$ in all fields of education and training.

Table 3.3. Targets for educational supply by 2016

\begin{tabular}{lrrr} 
Field and level of education & $\begin{array}{r}\text { Entrants } \\
\mathbf{2 0 0 9}\end{array}$ & $\begin{array}{r}\text { Entrant target } \\
\text { by 2016 }\end{array}$ & $\begin{array}{r}\text { Estimation for } \\
\text { the production of } \\
\text { qualifications }\end{array}$ \\
Social services, health and sports & 17324 & 18590 & 15337 \\
Vocational upper secondary ed-ucation and training & 8050 & 8930 & 7477 \\
Polytechnics & 7552 & 7700 & 6046 \\
Universities & 1722 & 1960 & 1714 \\
In total, all fields and levels & 98380 & 93450 & 72050 \\
\hline
\end{tabular}

* An estimation for the number of the qualifications is produced on the basis of the entrant targets for 2016.

Table 3.4. Natural wastage, changes of employed people and job openings in 2008-2025

\begin{tabular}{lrrrr} 
Industry & Employed people & Natural wast-age & \multicolumn{2}{c}{ Target scenario } \\
\cline { 3 - 5 } & & & Change & Job openings \\
\cline { 3 - 4 } & $\mathbf{2 0 0 7}$ & $\mathbf{2 0 0 8 - 2 0 2 5}$ & $\mathbf{2 0 0 8 - 2 0 2 5}$ & $\mathbf{2 0 0 8 - 2 0 2 5}$ \\
Health and Social work & 317,700 & 157,930 & 77,510 & 235,450 \\
Total all indus-tries & $2,369,080$ & $1,094,140$ & 48,640 & $1,142,790$ \\
\hline
\end{tabular}

Source: http://www.minedu.fi/export/sites/default/OPM/Julkaisut/2011/liitteet/tr16.pdf?lang=fi 


\subsection{Strategies}

\subsubsection{Perception of challenges}

The focus of the Finnish social and health policy is shifted from the treatment of problems to promoting physical, mental and social wellbeing and preventing problems across the entire population. Health 2015 is a long-term health policy programme whose purpose is to improve health and functional capacity to allow people to lead longer active lives, and to reduce health differentials between population groups. The implementation of the programme is based on the principle of health in all policies, seeking to promote health and wellbeing not only in health care but in all areas of society.

Social services and primary health care run by local municipalities, have been gradually merged into integrated service entities. This started from merging the administration and support services, but expanded in the 1990s to redesign actual service provision. The most advanced fields of integration are the care of older people and the mental health services and related psycho-social services, including services related to substance abuse. There is currently an emerging trend to integrate children's health services with child protection and support to families with children. In many local municipalities the two sectors share a genuine interest in promotion of health and well-being of the population through intersectoral co-operation reaching broader than the health and social sectors only.

The purpose of the new Act on Supporting the Functional Capacity of the Ageing Population and on Social and Health Care Services for Older People (980/2012) is to ensure that local authorities prepare for the forthcoming demographic changes. Local authorities are required to draw up the municipal council a plan for supporting the wellbeing of the ageing population and the availability of social welfare and health care services for older people. Moreover, the sufficiency and quality of the services has to be evaluated on an annual basis.

The precedence is given to services provided at home. Institutional long-term care can be provided only if it is medically justified or if it is otherwise appropriate to ensure a dignified life and safe care for an older person. Older people must also have an opportunity to take part in the preparation of decisions concerning their living conditions and services. 


\subsubsection{Ensuring sufficient, skilled and well-functioning personnel}

In addition to restructuring the service system (see 3.1.1) and increasing education and training, Finland emphasizes that labor demand can only be met by means of a wide set of personnel policy and management interventions and by developing the methods (such as increasing productivity, developing skill mix, advanced roles of nurses, multi-professional teams and collaboration and preventive services, using applied E-health technology, supporting the patients capacity on self-care, help-to-selfhelp etc.). For example, the re-delegation of professional responsibilities between professional groups in the health care sector has been promoted by means of legislative changes and regional and local pilot projects, which have been supported through the health policy programmes adopted by the Government. Furthermore, the roles of different professional groups will be reviewed and adjusted in accordance with the requirements of the integrated social and health service structure.

The Government adopts the National Development Programme for Social Welfare and Health Care, the Kaste programme, every four years (Act on Planning and Government Grants for Social Welfare and Health Care 733/1992, section 5). This is a strategic steering tool in order to manage and reform social and health policy. The Kaste Programme implements the Government Programme and the Strategy of the Ministry of Social Affairs and Health by means of defining the key social and health policy targets and priority action areas for development activities and monitoring. The programme also defines the major legislative projects, programmes, recommendations and priorities for supervision by which the achievement of the objectives is supported. The targets of the current Kaste programme 2012-2015 are as follows:

- Inequalities in wellbeing and health will be reduced.

- Social welfare and health care structures and services will be organised in a client-oriented and economically sustainable way.

One of the sub-programmes of the current Kaste programme is particularly focused on ensuring sufficient, skilled, and well-functioning personnel in the care sector through management. Corresponding activities concern for instance the development of tools for the management of human resources, engagement of the personnel in the development activities, a framework for specialised postgraduate education, and multiprofessional training environments focusing on inter-disciplinarity. 
The objectives of the Kaste programme are achieved through cooperation by the local authorities and joint municipal boards, the different branches of government, NGOs, parishes, companies, educational units, and national and regional research, and development units. In total, roughly EUR 58 million has been allocated for the project financing based on the Kaste programme in 2012-2015. Municipalities and joint municipal boards for social welfare and health care can apply for discretionary government transfers for creating and implementing good practices based on the Kaste programme. The Ministry of Social Affairs and Health also coordinates other project financing for social welfare and health care targeted to local authorities, joint municipal boards, NGOs and companies in collaboration together with different financiers. In addition to project financing, different actors use their own resources for the reform in accordance with the policy lines laid out in the programme.

\subsubsection{Continuous monitoring of the sufficiency of the workforce}

Educational supply is evaluated in the middle of the implementation period of the development plan for education and university research. This process is commissioned by the Ministry of Education and Culture. During this process, the production of the qualifications is compared to the entrant targets and assessed in relation to the sufficiency of workforce (shortages among different professional and vocational groups, changes in professional roles and the service structure, etc.).

The National Institute for Health and Welfare (THL) monitors workforce development on a yearly basis, both for the municipality sector (Public Health Care) and the health care total (public and private sectors), and for health care professionals' emigration and immigration from/to Finland. The reports are published yearly on the website of the National Institute for Health and Welfare.

The Finnish Medical Association and the Finnish Dental Association together with Local government employers collect information on physicians and dentist shortages in municipal health centers. Local government employers also prepare surveys on the shortages of the medical specialists in hospitals as well as other professional and vocational groups in municipal social and health care. These surveys on shortages are carried out in collaboration with the Ministry of Social Affairs and Health.

According to the Act on social and health review (879/2002), the Ministry of Social Affairs and Health gives a report regarding the population's state of welfare and health and the measures adopted to improve 
these every four years. The review constitutes supplementary material to the Government Report to the Parliament. The report has also included descriptions and assessments on the sufficiency of the workforce in social and health care as well as on related changes and measures.

\subsubsection{Initiatives - an overview}

The overall strategies described above have led to various initiatives, some of which are linked to local workplaces or educational institutions, others to ministries. The key initiatives are:

- A trial period with a new and shorter education as närvårdereassistent, which can supplement the traditional närvårdere (health care workers).

- Pilot projects about recruitment of foreign personnel.

- Participation in the Joint Action on Health Workforce Planning and Forecasting.

The initiatives are described in detail in "Velfærdsprofessioners- og uddannelsers attraktivitet I Norden - delstudie 2". However, due to the obvious relevancy of the initiatives to this study, they are described in brief below. In addition, they are listed in table 3.5 below.

\begin{tabular}{|c|c|c|c|c|}
\hline & \multicolumn{2}{|c|}{ Education } & \multicolumn{2}{|c|}{ Workplace } \\
\hline & Recruitment & Retention & Recruitment & Retention \\
\hline $\begin{array}{l}\text { Examples of } \\
\text { initiatives }\end{array}$ & $\begin{array}{l}\text { Campaigns } \\
\text { Increased intake } \\
\text { New educational } \\
\text { pro-grammes }\end{array}$ & $\begin{array}{l}\text { Mentoring pro- } \\
\text { grammes } \\
\text { Reforms }\end{array}$ & $\begin{array}{l}\text { Attracting foreign } \\
\text { health care person-nel, } \\
\text { Campaigns }\end{array}$ & $\begin{array}{l}\text { Conditions of em- } \\
\text { ployment } \\
\text { Work/life balance } \\
\text { Working environ-ment } \\
\text { Continuing education } \\
\text { and training } \\
\text { Management } \\
\text { Talent Management }\end{array}$ \\
\hline Finland & $\begin{array}{l}\text { "Styrka åt } \\
\text { omsorgen - vo- } \\
\text { ima hoivan" } \\
\text { Increased intake } \\
\text { New shorter } \\
\text { education to } \\
\text { närvårdere- } \\
\text { assistent (trial } \\
\text { period) }\end{array}$ & & $\begin{array}{l}\text { Pilot projects recruiting } \\
\text { foreign personnel }\end{array}$ & $\begin{array}{l}\text { KASTE-programme, } \\
\text { entailing continuing } \\
\text { education }\end{array}$ \\
\hline
\end{tabular}




\section{New education: närvårdere assistant}

The idea behind the establishment of a new education is that the new assistants can remedy the shortage of närvårdere. The employers' organisation in Finland welcome the new education, but the professional organisations in Finland worry that the new education will impact the status, salary and general working conditions of the profession.

\section{Recruiting foreign labor within the health professions}

The initiatives related to the recruitment of foreign labor are generally anchored at a local level. One of the bigger hospitals in Finland has focused on recruiting nurses from the Philippines, and an educational institution has established an international education, where only students from outside of Finland are recruited, e.g. students from Russia and Southern Europe.

This solution, however, has proven to be problematic. Thus, the foreign students left the area after finishing their education, and climateand language barriers seem to be too hard to overcome for most of the students.

\section{Collaboration in the EU}

Finland participates in the Joint Action on Health Workforce Planning and Forecasting (EUHWForce) under the second Health Programme. The Joint Action will be carried out between 2013 and 2016. The EUHWForce provides a platform for cooperation between the Commission and Member States on forecasting and planning health workforce in close collaboration with Eurostat, OECD, WHO and other partners. Altogether 30 associated partners and 26 collaborating partners are involved in this Joint Action.

The general objective of the EUHWForce is to put in to practice a platform for collaboration of the member states and to support them to take effective and sustainable measures to prepare the future of the health work force. This will support the member states and Europe in their capacity to address the supply and demand for health professionals. In addition, various tools will be developed to enable the member states to implement health workforce planning and/or to enhance their current planning processes. 


\subsubsection{Concluding remarks}

The results from Finland point to a shortage of health professional. However, it is not certain which professions will be most needed. It is evident that the Finnish authorities have taken a very holistic approach, exemplified in the large scale project KASTE-programme, which entails a sub-programme particularly focused on ensuring sufficient, skilled and well-functioning personnel by focusing on specialised postgraduate education and multi-professional training environments focusing on interdisciplinarity. Various actors take part in the programme, stressing the holistic perspective in Finland. Moreover, concrete initiatives have been launched as described above. The effects hereof are, however, not yet evaluated. 


\section{Appendix 3: Iceland}

\subsection{Framework conditions ${ }^{28}$}

\subsubsection{Judicial structure and organization}

The Icelandic health care sector has undergone important changes over the last decades, and is regulated in the Health Service Act from 2007. While Iceland is divided into two administrative levels - the state and municipalities - the role of local authorities within the health care sector is almost non-existent. Today, after a period of centralisation, they play a very limited role in the management and implementation of the country's health care services. It is defined by law that;

"The country shall be divided into health regions that will be further described in regulation. The health care services in each geographic region shall cooperate in planning the services in the region. The minister can, after referring with the local county or counties decide to merge the services in the region into one with a regulation."

Thus, decision-making, enforcement as well as management are concentrated at the level of the central government, and the Minister of Health is ultimately responsible for the administration of any health care service in the country. ${ }^{29}$

Iceland is divided into seven health regions ${ }^{30}$ with 15 geographical health institutions that can include several primary health care centres and a number of municipal hospitals. Where conditions permit, these hospitals and health care centres are located within the same building. The primary health care centres' main task is primary care, which - in the Health Services Act - is defined as general medical care, emergency ser-

\footnotetext{
${ }^{28}$ The information in this chapter is based on interviews with people from the Ministry of Welfare and "The Icelandic Health care system" (Tinna Asgeirdóttir, 2009).

${ }^{29}$ On 31 December 2010 the Ministry of Health was merged with the Ministry of Social Affairs and Social Security to form the Ministry of Welfare. However, the Ministry has two different ministers affiliated, A minister of Health and A minister of social affairs and housing. 30 http://eng.velferdarraduneyti.is/media/acrobat-enskar_sidur/Health_Service_Act-No_40_2007 _as_amended.pdf
} 
vices, nursing, preventive health care measures, as well as any type of medical care necessary outside of hospitals. The centres are all publicly run, based on fixed budgets. The legislation that introduced health care regions in 2007 states that the regional centres "shall cooperate in conformation of services in the region." Thus, the purpose was not so much to decentralise as to increase cooperation within the regions in order to mitigate the challenges regarding the small size of the population. Because of the small size of the population, economies of scale is difficult to realise within sparsely populated areas. Part of the centralisation has to do with the fact that $62 \%$ of the 320,000 people in the country live in and around the capital of Reykjavik on the Southwest cost. The fact that the Icelandic health care sector is strongly centralised is expressed in table 4.1 below, with the state level being responsible for most health care services.

\begin{tabular}{|c|c|c|c|}
\hline Level & Institution & \multicolumn{2}{|l|}{ Tasks } \\
\hline National & State & $\begin{array}{l}\text { The Directorate of Health: } \\
\text { - Overall inspection and monitoring of } \\
\text { - Regulating and licensing of health pr } \\
\text { - Setting standards of health care qual } \\
\text { - Organizing public health measures in } \\
\text { programs } \\
\text { - Sponsoring health promotion initiati } \\
\text { - Collecting and processing data on he } \\
\text { - Promoting research } \\
\text { - Handling complaints from health car } \\
\text { The Icelandic Health Insurance Agency } \\
\text { - Administers public health insurance } \\
\text { - Negotiates contracts in addition to } p \\
\text { services provided by public and indep } \\
\text { The Icelandic Medicines Agency: } \\
\text { - Responsible for ensuring consumer } \\
\text { safety of medicinal products } \\
\text { The Icelandic Medicine Pricing and Re } \\
\text { - Makes decisions about reimburseme } \\
\text { sale pricing and retail pharmacy mark- } \\
\text { Primary Health Care provided by the } \\
\text { them) and rural Hospitals that are also } \\
\text { Landspitali - the National University } \\
\text { pital in Iceland. }\end{array}$ & $\begin{array}{l}\text { types of health care services } \\
\text { ansionals } \\
\text { and clinical guidelines } \\
\text { ding immunization and vaccination } \\
\text { hand health care service } \\
\text { Isers } \\
\text { deccupsing and paying for health care } \\
\text { tection by assessing the quality and } \\
\text { bursement Committee: } \\
\text { s and pricing of pharmaceuticals, whole- } \\
\text { levels } \\
\text { art of the Health Care Regions. } \\
\text { pital of Iceland is by far the biggest hos- }\end{array}$ \\
\hline & $\begin{array}{l}7 \text { Health } \\
\text { Regions }\end{array}$ & $\begin{array}{l}15 \text { regional Health care institutions } \\
\text { including the Primary Health Care of } \\
\text { the Capital Area: that runs } 15 \text { health } \\
\text { clinics in the capital area with GP's }\end{array}$ & $\begin{array}{l}\text { - medical and nursing services } \\
\text { - general medical services } \\
\text { - infant or maternity services } \\
\text { - preventive primary school health ser- } \\
\text { vices - vaccinations for adults } \\
\text { - health care for elderly } \\
\text { - mass screening }\end{array}$ \\
\hline
\end{tabular}


However, in addition to the mainly state run health care centres and hospitals, there are specialist working on a fee-for-service basis negotiated by the medical associations and the central health authorities. These private practitioners handle most of the outpatient care. In contrast to the other Nordic countries, with the exemption of Sweden, Icelandic citizens can directly approach these specialists without having consulted the GP's in the health care centres. Recently there has been an increase in the number of specialist due to the fact that specialists can start practicing with little impediments, while the number of GPs is regulated by the government.

\subsubsection{Financing}

The Icelandic health care system is financed through taxes levied by the central government. Since 2007, funding by local authorities has not been used to any extent. Taxes' share of the costs of the Icelandic health care sector amounts to around 82\% (2011 figures, OECD). The remaining percentage is almost exclusively financed by out-of-pocket money. The costsharing schemes apply to primary care visits, diagnostic, preventive and screening services, vaccination programs and pharmaceuticals as well as dental service. The ratio between taxes and out-of-pocket money is similar to the other Nordic countries, except for Finland.

There is almost no private health insurance in Iceland although law does not prohibit these. Only new residents waiting to be eligible for the public scheme insurance purchase a private insurance.

The state pays the total operating costs of the health care centres. Since 2007 the state has taken over all costs, and the administrative units within the health care centres have now been abolished. According to legislation from 2007, the regional health centres have a board of three members; a general director, who has final responsibility, and medical and nursing directors. For the larger hospitals the board can be larger with representatives of the specialist professions. 


\subsection{Challenges}

\subsubsection{Demographic challenges}

\begin{tabular}{|c|c|c|c|c|c|}
\hline & 2013 & 2020 & 2030 & 2040 & 2050 \\
\hline $60-69$ years & 29,869 & 37,082 & 40,970 & 42,210 & 47,160 \\
\hline $70-79$ years & 16,831 & 22,694 & 32,778 & 36,833 & 38,676 \\
\hline $80-89$ years & 9,943 & 10,380 & 15,388 & 23,057 & 26,738 \\
\hline $90-99$ years & 1,661 & 2,532 & 3,034 & 5,221 & 8,289 \\
\hline+100 years & 42 & 35 & 82 & 107 & 230 \\
\hline
\end{tabular}

Source: Statistics Iceland.

Note: Prediction from 2013, medium variant

The Icelandic population is relatively young in comparison to other Western countries. However, over the coming decades Iceland's age composition will rapidly approach the trends commonly seen in Europe today. Statistics Iceland's medium variant projection of the Icelandic population's development estimates that the entire population will increase from about 320,000 in 2013 to 416,000 in 2050. This is a growth of about $29 \%$ According to Statistics Iceland, the main reason for the growing population is the expected high net migration. But the higher life expectancy also plays an important role. The Icelandic average life span for men is predicted to increase from 80.8 in 2013 to 86.8 in 2060, and from 83.9 to 88.2 for women. The Icelandic population will therefore not just grow bigger but also older towards 2050.

In 2013 those who are 65 and older amount to $13 \%$ of the population, but by 2030 their share will have risen to $19 \%$ and by 2050 to $23 \%$ of the population.

The growth in the share of elderly in the population is followed by a diminished proportion of children aged 0-14: While this group makes up $21 \%$ of the population in 2013 , it is expected to decrease to $19 \%$ by 2030 and $17 \%$ by 2050 . The share of people in the working age from $15-$ 65 , who are the taxpayers, will slightly decrease. While they make up $66 \%$ of the population in 2013 , the share is expected to decrease to $62 \%$ by 2030 and $59 \%$ by 2050 .

Figure 4.3 shows how the different age groups of elderly divided up in 10 year spans will increase steadily every decade towards 2050. By 2050, all the age groups will have grown substantially and the age cohort from 90-99 will contain more than four times as many citizens as in 2013. 
Figure 4.3. Projection of Icelandic age cohorts 15-64 and 65+ from 2013 to 2050

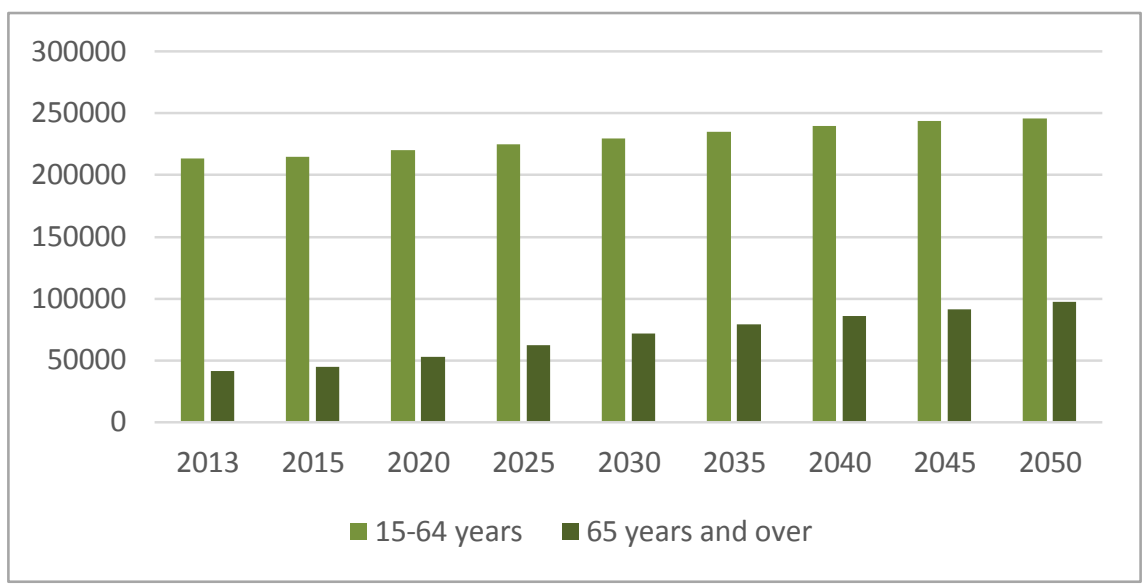

Source: Statistics Iceland.

Note: Predictions from 2013, medium variant.

The changing age composition of the Icelandic population will entail new challenges for the Icelandic health system. Figure 4.3 shows how the number of Icelandic citizens over 65 years of age will increase much faster than the working-able group of people aged 15-64, thereby putting an increasing burden on the Icelandic health system. This burden consists both of there being more elderly with more health issues than the rest of the population, and of there being relatively fewer of those aged 15-64 to look after the elderly and pay for their services through taxes.

\subsubsection{The Icelandic work force and unemployment}

Table 4.4 shows how the Icelandic unemployment grew in the beginning of the 2000's until 2004 where it started decreasing. It then took a great leap in 2009 corresponding with the global financial crisis. From 2012, however, the unemployment rate has again started to decrease. During the worst years of the economic crisis in 2009-11, men were harder afflicted with unemployment than women - but male unemployment is again close to that of women in 2012 . 
Table 4.4. Average number of Registered Unemployment in Iceland by year and gender

\begin{tabular}{lrrr} 
& Total & Males & Females \\
2000 & 1865 & 731 & 1134 \\
2001 & 2009 & 830 & 1179 \\
2002 & 3631 & 1794 & 1837 \\
2003 & 4893 & 2474 & 2419 \\
2004 & 4564 & 2164 & 2399 \\
2005 & 3120 & 1343 & 1777 \\
2006 & 2017 & 866 & 1150 \\
2007 & 1632 & 721 & 911 \\
2008 & 2744 & 1491 & 1253 \\
2009 & 13407 & 8270 & 5137 \\
2010 & 13309 & 7873 & 5436 \\
2011 & 12167 & 6832 & 5336 \\
2012 & 9505 & 4997 & 4508 \\
\hline
\end{tabular}

Source: Statistics Iceland.

Note: Unemployment figures are calculated as the total number of registered unemployment days each month divided by the average number of monthly working days (21,67 days) until 2001 when the full-time unemployment equivalents are calculated on the basis of actual number of working days per month.

\subsubsection{Recruitment and retention of students and health professionals}

\section{Recruitment in the educational sector}

The purpose of this section is to highlight the quantitative aspects of the recruitment to the Icelandic health care sector. Tables 4.5-4.9 show the intake for social and health care assistants, physiotherapy, nursing, assistant nursing and medicine students.

At the universities and secondary schools, the study places have been filled every year and are expected to continue to be so in the near future. The number of graduated doctors and nurses is expected to be sufficient for the next 15 years if emigration does not increase from what it is now. However, the trend seems to be increasing emigration, which will be described in detail below. Following the financial crisis, more people applied to get into the health professions due to a raise in the youth unemployment, which meant that quite a few of the health professionals lost their jobs in the private sector. Additionally, there were layoffs in the public sector, especially within nursing.

Table 4.5. Registered social and health care students by year and gender

\begin{tabular}{lrrrrr} 
& $\mathbf{2 0 0 7}$ & $\mathbf{2 0 0 8}$ & $\mathbf{2 0 0 9}$ & $\mathbf{2 0 1 0}$ & $\mathbf{2 0 1 1}$ \\
Total & 199 & 247 & 197 & 200 & 268 \\
Males & 19 & 25 & 23 & 14 & 26 \\
Females & 180 & 222 & 174 & 186 & 242 \\
\hline
\end{tabular}

Source: Statistics Iceland. 
Table 4.6. Registered Physiotherapy students by year and gender

\begin{tabular}{l|ccccc} 
& $\mathbf{2 0 0 7}$ & $\mathbf{2 0 0 8}$ & $\mathbf{2 0 0 9}$ & $\mathbf{2 0 1 0}$ & $\mathbf{2 0 1 1}$ \\
\hline Total & 90 & 86 & 80 & 89 & 96 \\
Males & 35 & 37 & 35 & 31 & 33 \\
Females & 55 & 49 & 45 & 58 & 63
\end{tabular}

Source: Statistics Iceland.

Table 4.7. Registered Nursing students by year and gender

\begin{tabular}{lrrrrr} 
& $\mathbf{2 0 0 7}$ & $\mathbf{2 0 0 8}$ & $\mathbf{2 0 0 9}$ & $\mathbf{2 0 1 0}$ & $\mathbf{2 0 1 1}$ \\
Total & 710 & 686 & 756 & 769 & 757 \\
Males & 18 & 17 & 20 & 16 & 19 \\
Females & 692 & 669 & 736 & 753 & 738 \\
\hline
\end{tabular}

Source: Statistics Iceland.

Table 4.8. Registered Medicine students (undergraduate, graduate and Ph.D. students) by year and gender

\begin{tabular}{lccccc} 
& $\mathbf{2 0 0 7}$ & $\mathbf{2 0 0 8}$ & $\mathbf{2 0 0 9}$ & $\mathbf{2 0 1 0}$ & $\mathbf{2 0 1 1}$ \\
Total & 342 & 323 & 307 & 295 & 297 \\
Males & 138 & 128 & 120 & 127 & 127 \\
Females & 204 & 195 & 187 & 168 & 170 \\
\hline
\end{tabular}

Source: Statistics Iceland.

Table 4.9. Registered Assistant Nurse students

\begin{tabular}{lrrrrr} 
& $\mathbf{2 0 0 7}$ & $\mathbf{2 0 0 8}$ & $\mathbf{2 0 0 9}$ & $\mathbf{2 0 1 0}$ & $\mathbf{2 0 1 1}$ \\
Total & 721 & 592 & 750 & 566 & 542 \\
Males & 20 & 18 & 43 & 15 & 20 \\
Females & 701 & 574 & 707 & 551 & 522 \\
\hline
\end{tabular}

Source: Statistics Iceland.

As tables 4.5-4.9 show, the intake of students in the Icelandic health educations has overall been stable from 2007-2011. With regards to the number of students, the student places have been filled in recent years, and at this stage an increase in the number of student places is not being contemplated. The tables also show that all the health educations have a larger female than male student body. This is particularly true for the nurse and assistant nurse educations, where the registered male students only amount to around $3 \%$ of the students. 
These gender imbalances have been stable for all the educational programs throughout the years, but nevertheless points to the fact that there could be a potential in trying to recruit more Icelandic men to the health professions.

\section{Troubles with retaining health professionals: Emigration from Iceland} Educating health professionals is not enough in order to secure that the future need of health professionals in Iceland are covered. It is also necessary to retain the health professionals in Iceland, which is an increasing challenge. Even though the overall emigration seems to have peaked according to figure 4.10 below, it is continuously a concern of the Icelandic authorities how to make sure that students who go abroad for graduate studies return to Iceland. Figure 4.10 also shows how immigration rose rather dramatically in Iceland from around 4,000 migrants in 2002 to more than 12,000 in 2007. It then started decreasing substantially in the wake of the financial crisis in 2008 and 2009, and started stabilising around 6,000 immigrants in 2009. Emigration in Iceland was stable from 2002 to 2006 at around 4,000 people per year, but then started increasing until 2009 where it peaked at more than 10,000. The number has fallen since then and was in 2012 only a bit higher than the immigration. The net migration chart shows how emigration and migration were close to even in 2002-4 until immigration took off in 2005-7 causing net migration to be positive these years. Then net migration started to fall, and it turned negative in 2009. Since then, net migration has started to even out, and by 2012 it was almost back at a migration of 0 . However, the emigration figures are the total amount, and not specific for health professionals. The unemployment crisis that emerged in the wake of the crash mainly affected low skilled and migrant workers from abroad, whereas is affected the health sector on a much smaller scale. From the interviews, however, it is evident that there is a challenge related to the migration from Iceland amongst health professionals and that it is necessary to take measures to counter the tendency. 
Figure 4.10. Total immigration, Emigration and Net immigration Iceland

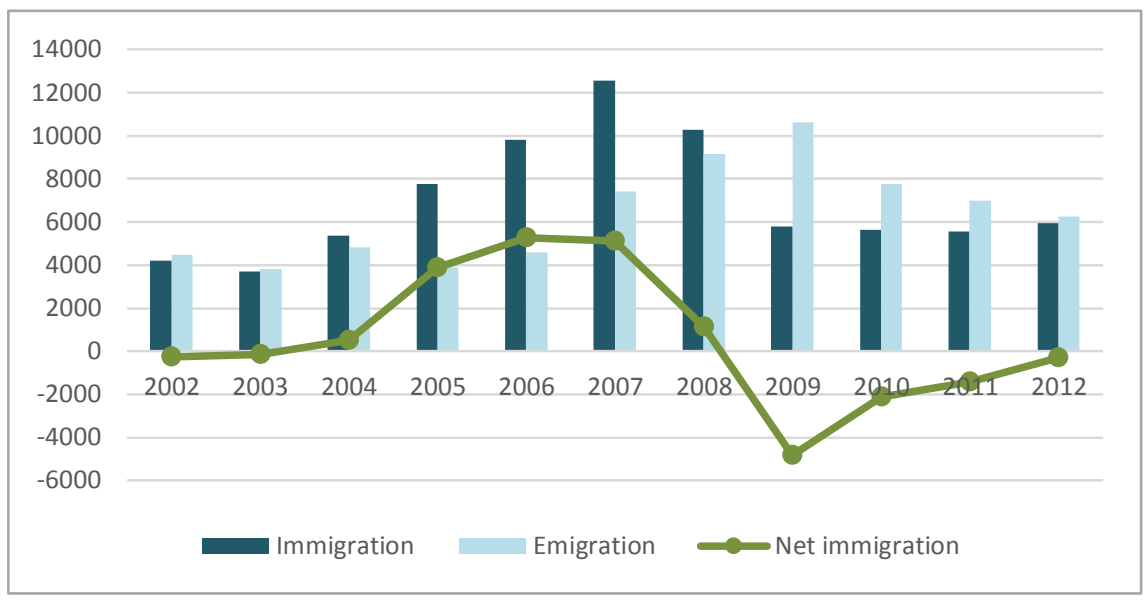

Source: Statistics Iceland.

Note: Until 1985 the National Register was only updated once a year with a reference date 1 December. Short term immigrations and emigrations that occurred between the reference dates were thus not noted. Multiple movements that occurred between the reference dates were not recorded but reduced to only one change of address. From 1986 all migration events are recorded as they happen. Included are all migration events that are recorded before 31 December each year.

\section{Commuting health professionals}

In this report, the word commuting health professionals is used both for those health professionals that go abroad for studying and return, and those that hold part time jobs abroad. Even though commuting is not a new phenomenon, it is raising concerns in these years, as people leave earlier for their post graduate education and come back to Iceland later, thereby decreasing the stock of health professionals in the country. Also, commuting for part time jobs is increasingly popular among Icelandic doctors and nurses due to higher wages and better working conditions abroad.

Icelandic nurses commute between Iceland and Scandinavia, mostly to Norway. According to the Icelandic Nurses' Association, a survey shows that seven percent of 2,800 union members have worked abroad in the past year (2012). This is also due to the fact that the work load is smaller in Norway than in Iceland due to cuts in hospital budgets.

This form of commuting is popular among Icelandic doctors too, and it has become increasingly popular in the wake of the economic crisis. Many doctors work part time in Iceland and part time in Scandinavia. Sometimes, a group of Icelandic doctors will share one or two positions in Scandinavia, taking turns to staff it. It is also popular to serve as substitutes abroad, especially in Sweden.

The understanding from a central perspective is that the migration is beneficial in many ways as the health professionals acquire experience and skills, which are useful for the Icelandic society. However, in recent 
years the health professionals stay longer abroad than earlier.It is therefore important from a central perspective to focus on attracting health professionals by improving working conditions. However, after the financial meltdown of the Icelandic economy in 2008, Icelandic doctors are generally facing longer hours, a higher work pressure, and lower wages than they would get in Scandinavian countries. This implies that the challenge in attracting especially nurses and doctors is very high on the agenda.

Figure 4.11 shows the number of Icelanders and how many of these are employed within the various professions. The figure shows a modest increase within each profession.

\begin{tabular}{|c|c|c|c|c|c|c|c|c|c|c|c|}
\hline $\begin{array}{l}\text { Number pr. } \\
\text { Year }\end{array}$ & 2001 & 2002 & 2003 & 2004 & 2005 & 2006 & 2007 & 2008 & 2009 & 2010 & 2011 \\
\hline Nurses & 2,325 & 2,342 & 2,474 & 2,525 & 2,546 & 2,567 & 2,729 & 2,729 & 2,686 & 2,653 & 2,765 \\
\hline $\begin{array}{l}\text { Practical } \\
\text { nurses }\end{array}$ & 1,420 & 1,474 & 1,474 & 1,474 & 1,600 & 1,600 & 1,632 & 1,997 & 2,185 & 1,972 & $\ldots$ \\
\hline $\begin{array}{l}\text { Occupational } \\
\text { therapists }\end{array}$ & 88 & .. & .. & 147 & 156 & 165 & 169 & 184 & 191 & 194 & 213 \\
\hline $\begin{array}{l}\text { Physio- } \\
\text { therapists }\end{array}$ & 415 & .. & .. & 410 & 420 & 425 & 450 & 475 & 470 & 473 & 470 \\
\hline $\begin{array}{l}\text { Social } \\
\text { workers }\end{array}$ & 122 & 123 & .. &.. &.. &.. & 300 & 331 & 356 & 394 & 378 \\
\hline
\end{tabular}

Source: Statics Iceland.

Note: The table shows the number of health personnel regardless of whether they work full time or part time. Social workers: Until 2002: The Direc-torate of Health. Figures refer to those working in inpatient care institutions and health centres. 2007 and onwards: The Icelandic Association of Social Workers.

Around $20 \%$ of Icelandic women are employed in Health Services and Social Work, whereas employment in these fields make up a much smaller percentage of Icelandic men's work. However, while the number of overall jobs employed by men dropped around 10,000 during the financial crisis, the number of men employed in the social and health care sector rose in the same period from $3.8 \%$ in 2008 to $5 \%$ in 2012 .

\section{Future needs}

In 2006, the Economic Institute of the University of Iceland prepared a report for the Ministry of Health. In the report, long term workforce needs for four key professions were predicted (doctors, nurses, associate nurses, and physiotherapists). The report pointed out that there is reason to be worried about the future number of especially nurses and 
doctors, but also some other social and health care workers. These professions are facing an increasing burden of chronic diseases among the patients and a growing elderly population. In 2012, the Ministry of Welfare reviewed the report from 2006 with similar results. This fact relates to the above-described concern about emigration/commuting, which is more prominent in the Icelandic society than elsewhere in the Nordic countries to judge from the interviews with key persons in the Ministry of Welfare. Thus, migration is viewed as the most pressing challenge concerning the future need of health professionals in Iceland.

\subsection{Strategies}

\subsubsection{Perception of challenges}

When it comes to the strategic responses to the challenges described above, these are fewer than in the rest of the Nordic countries. Changes have been made, and the intake of new students has increased, both in nursing and in medicine. One must take into account the small size of the country, which influences the level of attention given to the strategic work. Iceland is often described as a very successful country in terms of welfare development in spite of the small size of the country, and that goes for the health care sector as well.

\subsubsection{Initiatives - an overview}

\section{European Collaboration}

One of the most important initiatives at this stage is Iceland's participation in the Joint Action for Health Workforce Planning and Forecasting (JAHWPF). This project is run under the auspices of the EU, and takes as its starting point the need of health professionals in the European Union, which is estimated to be around 1,000,000 (sic) in 2020. The general objective of the project is a platform for collaboration and exchange to prepare for the future in the partnering countries. Among the Nordic countries, Iceland (Ministry of Welfare) and Finland (Ministry of Social Affairs and Health and University of Eastern Finland) are associated partners, while Denmark (Danish National Board of Health), Norway (the Norwegian Ministry of Health and care Services) and Sweden (Socialstyrelsen - the National Board of Health and Welfare) are collaborating partners. Thus, the overall strategy with participating in this project is to put more focus on monitoring the need and cooperating with other 
European countries about the future challenges. The initiative is described further in table 4.12 below.

\begin{tabular}{l} 
Table 4.12. Joint Action Health Workforce Planning and Forecasting \\
Jitle: \\
Joint Action Health Workforce Planning and Forecasting \\
Initiative-taker: \\
$\begin{array}{l}\text { Year /time period: } \\
\text { Description: }\end{array}$ \\
$\begin{array}{l}\text { The intention is to create a European platform to share good practice and to } \\
\text { develop methodologies on forecasting health workforce and skills needs }\end{array}$ \\
Classification of instrument: $\quad$ Monitoring, analysis and strategic planning \\
Target group \\
What is expected to change? $\quad \begin{array}{l}\text { The changes are related to the exchange of experience and share of good } \\
\text { prac-tice among the European countries, albeit the need in the various } \\
\text { countries are currently very different. }\end{array}$ \\
\hline
\end{tabular}

Source: Interview with the Icelandic Ministry of Welfare and the JAHWF website at http://www.euhwforce.eu/

As mentioned, the authorities are aware of the challenges related to the migration patterns of Icelandic health professionals. This theme makes it increasingly important to act and make it more attractive to work in the Icelandic health care sector. Thus, the Ministry of Welfare is currently working on a strategy looking into what can be done in the short and long run in order to retain health care personnel in Iceland. Some of the focus points in the strategic work is better housing such as new buildings for the Landspítali National University Hospital that would boost the morale among the health professionals. However, this is expensive and has currently been put on hold. Another part of the strategic work is to focus on establishing research network, as a lot of the nurses and doctors who leave Iceland are leaving because of the stronger research environments in the rest of the Nordic countries. Thus, one way of attracting and/or making health professionals stay is to focus on strong research environments.

\section{A commuting market}

The fact that the Nordic countries are quite integrated in terms of health professionals is highlighted with a private initiative, which is facilitating commuting within the Nordic region. There are agencies that assist doctors, nurses and midwives in finding work abroad - mainly in Sweden. These agencies cater for the private market in the Nordic countries and have found several hundreds of jobs for Icelandic health professionals in recent years. The demand is large. Sweden and especially Norway need 
health professionals and many Icelandic doctors have spent years in in Scandinavia, especially Sweden for their graduate specialist training, which means that they speak fluent Swedish or Norwegian. Thus, no language barrier is present. Even though the flow is mainly out of Iceland, the initiative-taker does not reject the possibilities of finding work for Swedish or Norwegian doctors in Iceland.

The tendency is supported by the fact that a larger amount of citizens within the health professions have applied for certification to be able to work outside of Iceland. While only 5 people applied in 2007, the number has been between 240 and 500 in 2010 and 2011 .

\subsubsection{Concluding remarks}

As evident in the sections above, the future shortage of health professionals is on the agenda in Iceland. However, when it comes to concrete initiatives, the findings are scarce.

The interviewees from the Ministry of Welfare made clear that they would be aware of any concrete initiatives launched with the specific aim of recruiting or retaining health professionals due to the small size of the country. For instance, no recruitment campaigns have been launched from a central level, which is a difference from the other Nordic countries.

The interviewees also highlight the fact that the amount of initiatives in Iceland should be seen in light of previous experiences with regards to predictions. This was exemplified when the financial crisis hit the private sector extremely hard, which lead private employed nurses back to the public sector and thus mitigated the shortage of nurses at this stage. However, as indicated above, the challenges related to the future shortage of health professionals are definitely on the agenda. 



\section{Appendix 4: Norway}

\subsection{Framework conditions}

\subsubsection{Judicial structure and organisation}

\begin{tabular}{|c|c|c|}
\hline Level & Institution & Tasks \\
\hline National & State & $\begin{array}{l}\text { The Ministry of Health and Care Services: } \\
\text { - The overall responsibility to secure that the population gets good and equal } \\
\text { health and care services. } \\
\text { - Manage the health and human services through a comprehensive set of } \\
\text { laws, annual grants and with the help of twelve governmental subordinate } \\
\text { institutions, businesses, and corporations. } \\
\text { - Has an overall responsibility for public health, municipal health and care } \\
\text { services, specialist health services, hospitals, health legislation, and budget } \\
\text { and financial affairs. } \\
\text { - Owns the hospitals. }\end{array}$ \\
\hline Regional & $\begin{array}{l}19 \text { counties } \\
\text { (18 admin- } \\
\text { istrative units) }\end{array}$ & $\begin{array}{l}\text { - Responsible for public dental care. } \\
\text { - The county has a statutory responsibility to promote public health within } \\
\text { specified areas and tasks, and shall coordinate the health care in the county. } \\
\text { - The primary area of responsibility is public health which is intersectoral and } \\
\text { across levels, and where it is a need for regional and local adaptions. }\end{array}$ \\
\hline Local & $\begin{array}{l}429 \text { munic- } \\
\text { ipalities }\end{array}$ & $\begin{array}{l}\text { - The municipals had the overall responsibility to offer necessary health and } \\
\text { care services to their residents. This includes primary health and care ser- } \\
\text { vices, health promotion, preventive medicine, rehabilitative services, emer- } \\
\text { gency ward, and long-term nursing care. } \\
\text { - The municipalities has responsibility to promote public health. } \\
\text { - Shall coordinate local initiatives with national and regional guidelines. }\end{array}$ \\
\hline
\end{tabular}

\section{Three levels of government}

The three levels of government are state, counties and municipalities. Each of the governmental levels have responsibility for different health and care services.

The Ministry of Health and Care Services has the overall responsibility to secure that the population gets good and equal health and care services. The Ministry manages the services through a comprehensive set of laws, annual grants and with the help of twelve governmental subordinate institutions, businesses, and corporations.

The Ministry of Health and Care Services has the overall responsibility for a number of tasks such as public health, specialist health services, nutrition and food safety, health services for drug addiction, alternative treat- 
ment, medicines/drugs, health emergency, the primary health and care services, nursing and care services, mental health, rehabilitation, patients' rights, biotechnology, and dental care. The responsibility cuts across the three organisational levels. The state, represented by the Ministry of Health and Care Services, owns and has the legal responsibility for the hospitals in Norway through four regional health enterprises (helseforetak). Laws regulate the ownership and organization of the hospitals.

The Ministry of Health and Care Services issues a yearly document instructing the four regional health enterprises' priorities, achievements, and budgets. The four health enterprises have the responsibility for supervising inpatient and specialist somatic and psychiatric care.

There are 19 counties in Norway, but only 18 administrative units. ${ }^{31}$ The counties have responsibility for dental care and public health for their residents. Overall, laws regulate the organization and responsibility of the counties.

Finally, there are 429 municipalities in Norway. These are very different both in terms of size of geographic area and population. The smallest municipality has approximately 200 residents, and the largest municipality (Oslo) has around 600,000 residents.

The municipalities are responsible for primary health and care services and for providing high-quality health care and social services to everyone in need of them. The municipalities' responsibility for health and care are regulated in law and associated regulations (Lov om kommuner og fylkeskommuner (kommuneloven) and Lov om kommunale helse- og omsorgstjenester m.m. (helse- og omsorgstjenesteloven)).

Some of the spheres included under municipal health and care services are: RGPs, care for the elderly, addiction and psychiatric health, municipal social services, dental care services, alternative treatment, public physiotherapy services and allocation of municipal services and the right to appeal.

The municipalities also decide on public health initiatives to promote a healthy lifestyle and reduce social health disparities.

The state is responsible for ensuring equal framework conditions for all municipalities. The municipalities' obligations are mainly laid out through legislation, earmarked funding, and an annual document issued

\footnotetext{
31 The county of Oslo and the County of Akershus have one administrative unit in common. Oslo is also both a county and a municipality.
} 
by the Directorate for Health concerning prioritizing and quality. The state carries the responsibility of exercising supervision and control.

\subsubsection{Reforms}

In recent years, there has been a series of major changes in the Norwegian health care system.

\section{Organisation of four regional health authorities}

In 2002, one of the most comprehensive reforms in the Norwegian public sector was introduced (Forskningsrådet 2007). The goal was to establish an overall and clear management of the specialist health service. The reform should also promote a clearer distribution of roles and responsibilities, so that the resources in the health sector could be better utilized. The reform resulted in the organisation of four regional health enterprises, fully owned by the state, and led to a centralisation of the responsibility of the hospitals previously held by the counties, cf. section 5.1.

The reform's two main elements were as follows:

- The state took over the ownership of and responsibility for the hospitals and other actors within the specialist health service. Sector responsibility, funding responsibility, and ownership was placed on one hand.

- The hospitals were organised into local companies, owned by four regional enterprises. The hospitals were transformed into separate legal entities with their own boards and are therefore no longer an integrated part of the central state administration. This gave the hospitals increased local authority.

\section{The Coordination Reform}

The Coordination reform took effect in 2012, focusing on prevention, care integration, and a strengthening of health care in the municipalities (Commonwealth Fund, 2012). The main goal of the reform was to give the patients help and assistance at an early stage close to where they live.

The reform introduced an economic incentive for municipalities to counter hospitalisation of their patients. In addition, the municipalities are obliged to establish primary care for patients who do not need specialised hospitalisation. 


\subsubsection{Financing}

\section{Who is covered?}

The coverage of the Norwegian health system is universal. The system is built on the principle that all legal residents have equal access regardless of socioeconomic status, country of origin, and area of resident (Lindahl 2012). Through common agreements within the EU, EU-residents have the same access to health services as legal residents.

Private and voluntary health insurance is growing, but cover only about $5 \%$ of health care services and then mainly elective services.

\section{How it is covered?}

Both the central government, counties, and municipalities collect taxes. The government sets an annual health budget, but parliament can vote for additional funds later in the year, particularly for hospitals. After the budget is passed, General Purpose Grant Scheme redistributes funds among municipalities according to population size, characteristics, and density (Lindahl 2012).

The four regional health enterprises are funded through capitation, activity-based payment, and through out-of-pocket payment (outpatient and day care). The hospitals are financed in much the same way. The activity-based part of the budget is set annually. $60 \%$ is provided as a fixed sum based on how many patients the hospital is expected to see, and $40 \%$ is set depending on the actual volume of patients treated.

The municipalities have mainly three income sources: taxes, government transfers, and user fees. The municipal resource use is mainly related to the municipalities' responsibility for welfare services. Kinder gardens, primary and lower secondary education, and the health and social sector occupies approximately $70 \%$ of the municipals' gross operating expenses.

The state manages the municipal sector through regulated limits on government transfer and through regulating the municipalities' income opportunities, which is a $\mathrm{n}$ important part of the municipal economy.

\section{What is covered?}

Even though coverage is universal for all legal residents and EUresidents, not all kinds of health and care services are covered by public funds, and the public coverage varies between the different health services (Lindahl 2012).

In practice, statutory national health insurance covers primary health care, hospital care, ambulatory care, and prescription drugs on the formulary (the "blue list"). It also partly covers dental care for children and 
youths and some other groups, but do not cover nonmedical eye care. All inpatient care in a public hospital, including use of pharmaceuticals, is free of charge for the patients. Complementary medicine is not covered.

Primary care (RGPs, physiotherapists, and chiropractors), preventive care, and nursing care are organised at the local level by the municipalities. The municipalities also decide on public health initiatives to promote a healthy lifestyle and reduce social health disparities. Preventive services for mental health are directed mostly towards children and older youths through the school system. Long-term care is also provided for those who need it (in their own homes, in care homes, or in institutions). In 2009, out-of-pocket payment accounted for $15 \%$ of total health care expenditure, mainly reflecting cost-sharing requirements.

RGP and specialist visit, including outpatient hospital care and sameday surgery, require co-payments. Co-payment also applies to physiotherapy, prescription drugs, and radiology and laboratory tests. Certain groups are exempted from cost sharing. Dental care, except dental care for children and youths, is mainly offered through private providers and are self-funded by the users.

\subsection{Challenges}

One of the most important challenges in the future is to ensure adequate access to health and welfare professionals at national, regional and local levels. Adequate and relevant competences are crucial to maintaining the Norwegian welfare society. Four areas are presented as challenging in the white paper National health care plan (2011-2015) (Meld. St. 16 (2010-2011)):

1. New groups in need of assistance: Strong growth in the need of assistance for those under 67 years. This is especially challenging for the home nursing services.

2. Aging: There will be an increasing demand for health and care professionals due to the increase of the proportion of elderly in the population. There will be a special need for competence within dementia and complex disorders.

3. Scarcity of health and care professionals: There will be scarcity both for professionals and of volunteers. A large proportion of those working in the health and care sector lacks formal, relevant, and higher education. 
4. Medical assistance: The medical and interdisciplinary assistance for those receiving home nursing and for those staying at nursing homes and care homes must be strengthened.

\subsubsection{Demographic challenges}

The most pressing challenges seem to be within elderly care, and in the white paper Future Care (Meld. St. 29 (2012-2013)), care services for the elderly are highlighted as one of the biggest future challenges in Norway due to the expected growth in the upper age cohorts.

At the beginning of 2013, 5,051,000 people were living in Norway. Of these, 449,000 was immigrants. The population is expected to reach 6 million by 2030 and 6.7 million by 2050 .

According to projection analyses, the population growth in Norway is expected to continue for some years, but will decline gradually after 2030. The expectations are based on assumptions related to changes in immigration for people from the EEA-area.

The growth in the Norwegian population can primarily be explained by high net immigration (Brunborg og Tønnesen 2013, Cappelen et al. 2013). Immigration is also the main explanation for the current increase in the "core" working age group of people between 25 - 66 years of age. This growth rate is forecasted to decline somewhat due to lower immigration during 2020 and 2030 (Cappelen et al. 2013).

At the same time, fewer people die than are born, and people live longer. From 1950, the number of elderly has been increasing considerably. Towards 2050 and 2100, we will see a continued increase in all age cohorts.

Currently, the number of people being 70 years or older account for about $10 \%$ of the total population in Norway (Brunborg et al. 2012). In 2070 , one expects about $20 \%$ of the population being 70 years or older. In the next few years, and after 2020 in particular, the highest growth is expected to occur among those between 67-79 years. The large cohorts born after the Second World War explains this. According to projections, the number over 67 years will more than double from 2000 to 2050. The population growth among those between 67-79 years old represents a particular challenge for the home care services.

According to the projections, the population growth will take place in all counties towards 2040. The growth will be strongest in Oslo, where the population size is expected to increase from 613,000 in 2012 to 832,000 in 2040. This correspond to a 1.3 percentage growth per year. Generally, the growth will be strongest in the counties where the largest cities are located or in counties close to the major cities. 


\subsubsection{Recruitment and retention in the health and care sector - Increased demand for labor}

The newest projections regarding employment by sector show very little change in terms of relative shares of employment (Cappelen et al. 2013). Towards 2030, the share of employment in the public sector is expected to increase by nearly two percentage points, and the increase is mainly driven by demographic factors leading to higher demand for health and social care for elderly people.

The overall employment within the health and welfare sector has almost doubled over the last 25 years (Meld. St. 13 (2011-2012)). In 2007, close to 500,000 people worked in the sector. This is the equivalent of more than one in five of those employed in total. Of these, close to $50 \%$ work in the municipal health care services, in which the number of employees has increased three times more than in the hospitals over the past five years. The main reason for the increase in the municipalities is that the municipalities have been given responsibility for new tasks, services, and user groups cf. the Coordination Reform.

In 2012, there were $1,761,903$ people employed in the private sector in Norway. 921,432 were employed in the public sector, and every fifth worked in the municipal sector. $36.8 \%$ of the man-years in the municipalities and counties fell within the health and care area (Arbeidsgivermonitoren 2013). $64.5 \%$ of the employees in the public sector are women, compared to $36 \%$ women employed in the private sector. Women dominate the public sector, and especially the municipal sector (Arbeidsgivermonitoren 2013). In 2012, 79\% of the employees in the municipalities were women. Among for example nurses, women are represented by approximately $90 \%$.

When looking at the share employed in the public and private sectors by age, the largest share in both sectors are in the cohort 25-39 years and 40-54 years. In the public sector, a larger share of the employees are in the 55-66 age cohort, compared with the equivalent cohort in private sector. To sum up, compared with the private sector and the state, the municipal sector has many employees in the upper age cohorts. 
Table 5.2. Employees by sector and age, 2012

\begin{tabular}{lrrrr} 
& \multicolumn{2}{c}{ Public sector } & \multicolumn{2}{c}{ Private sector } \\
Age & Number & Pct. & Number & Pct. \\
$15-24$ & 73,864 & 8 & 277,630 & 16 \\
$25-39$ & 268,656 & 29 & 585,768 & 33 \\
$40-54$ & 350,177 & 38 & 564,133 & 32 \\
$55-66$ & 210,201 & 23 & 272,914 & 15 \\
$67+$ & 18,534 & 2 & 61,458 & 3 \\
Total & 921,432 & 100 & $1,761,903$ & 100 \\
\hline
\end{tabular}

Source: Statistics Norway .

Note: This applies to full-time work.

Through the 2000s, Norway has had a low unemployment rate compared with many other countries. The average unemployment rate from 2000 to 2012 was $2.8 \%$, cf. figure 5.3 below.

Figure 5.3. Unemployment rates through the 2000s in Norway

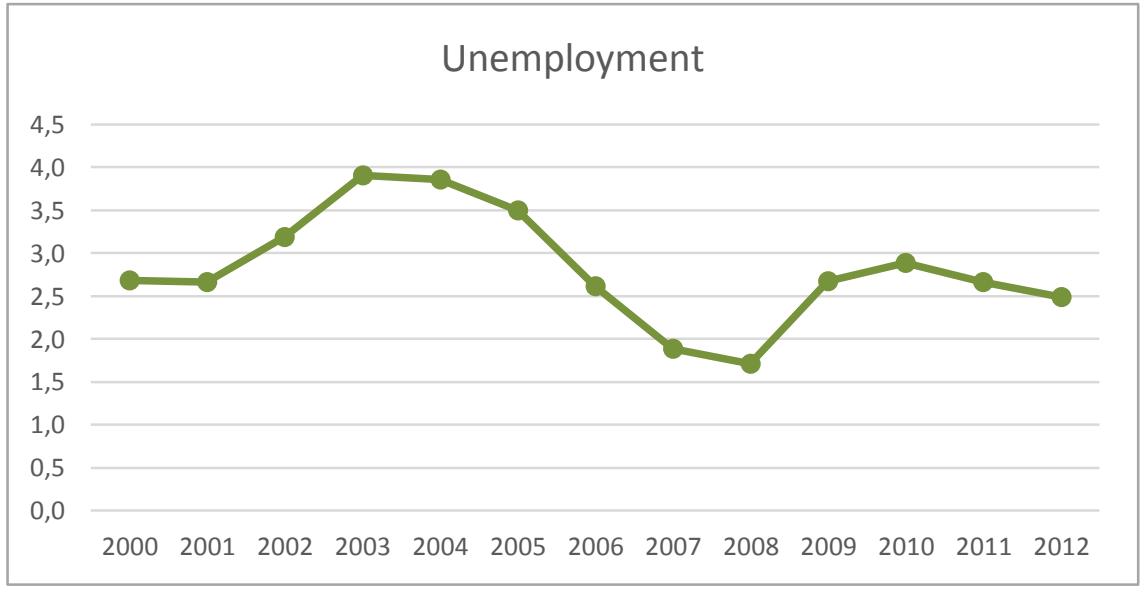

Source: Statistics Norway

As shown in table 5.5, the vacancy in the health and care industry is particularly high within nursing and care services in institutions compared with the average for all industries. Projections shows that there will be an increased demand for labour in the health and care sector, especially due to the large proportion of elderly in the population (Meld. St. 29 (2012-2013)). 


\begin{tabular}{lrrr} 
Table 5.5. Vacancies by industries 2010-2012 & $\mathbf{2 0 1 0}$ & $\mathbf{2 0 1 1}$ & $\mathbf{2 0 1 2}$ \\
& & & \\
Industries & Vacancies (pct.) & Vacancies (pct.) & Vacancies (pct.) \\
All industries & 2,5 & 2,8 & 2,6 \\
Health services & 2,0 & 2,0 & 2,1 \\
Nursing and care services in institutions & 5,5 & 5,8 & 3,8 \\
Social health services with-out accommodation & 2,8 & 2,7 & 2,4 \\
\hline
\end{tabular}

The annual growth in demand will be at its peak in 2030, with need for approximately 6,000 new man-year annually. The growth will stabilise after 2040 at a level of approximately 4,000 man-years annually. In 2000 , there were 4.7 people of working age per elderly, while the coefficient is reduced to $3.5 \%$ in 2030 and 2.9 in 2050.

The decline in the proportion of people of working-age in relation to the proportion of elderly will be a challenge for the employment in the health and care service sector and for the value creation and welfare development in Norway.

Figure 5.4. The number of people in the working-age (16-22 years) per number of elderly in the cohort 65 years and more, 2000-2050

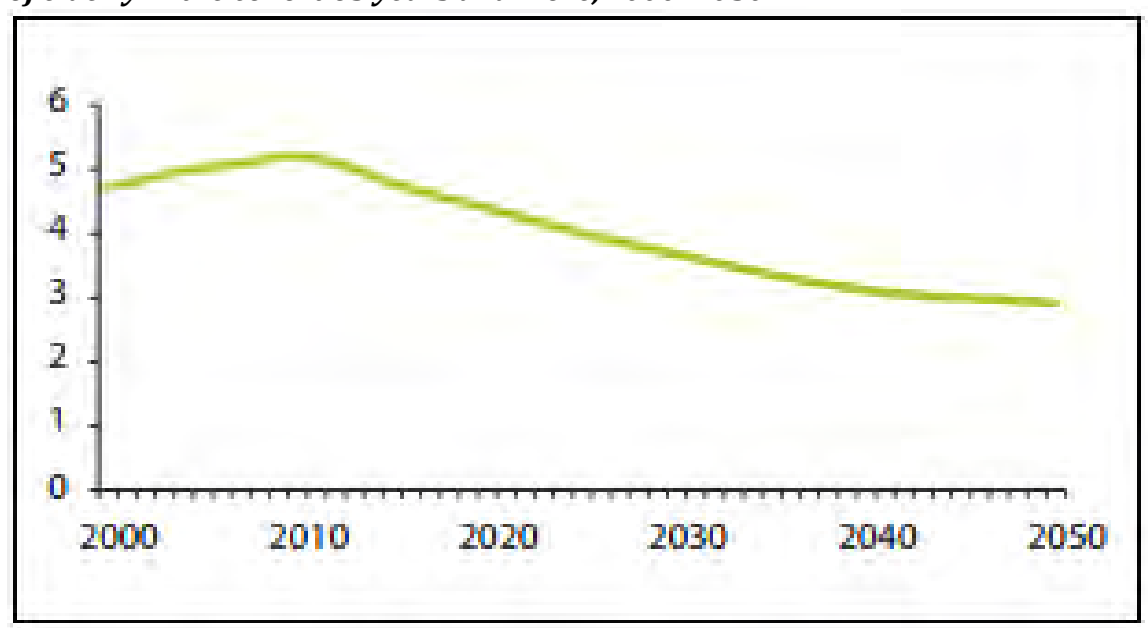

Source: Statistics Norway.

Note: From the White paper: Meld. St. 29 (2012-2013) Morgendagens omsorg, p. 41. 
The demand for labor in the health, social and care sector is expected to grow $16.9 \%$ towards 2022.32 This corresponds to approximately 32,000 persons.

According to projections, towards 2022 the labor force in the Norwegian municipalities and counties

must grow by $12.9 \%$ to obtain the current services offered. ${ }^{33}$ This corresponds to approximately 60,000 persons.

Towards 2022, 373,500 persons are expected to quit their jobs in the health, social and care sector. To cover the upcoming labor need in these sectors, it will be necessary to employ 406,000 people.

The need for employees in the personnel category "skilled worker/social/care" (including nursing assistants) is expected to increase by almost 13,000 towards 2022.34 This represents an increase of $19 \%$.

\subsubsection{Retaining at the workplace}

From the conducted interviews, there is little evidence that it is a significant problem to retain staff in the health and care sector. However, an interviewee pointed out that there is a relatively high turn-over within the health and care sector in the sense that employees change jobs within the sector many operational staff transfer to management positions. Thus, retaining staff as warm hands can be a challenge.

At the same time, it is a challenge that employees in the health and care sector retire early, which can be explained by physically demanding tasks in combination with the large proportion of women employed in the health and care sector. When it comes to demand and supply, several of the informants said that there is a mismatch between the health and care sector's need for competences and the supply of professionals, and many of the informants call for stronger governmental control of the educational sector considering the educational provision offered.

Several of the interviewees explained some of the mismatch by the fact that more and more of the higher educational institutions provide a Master's degree for nurses, while the health and care sector generally requests nurses with a Bachelor's degree. Another aspect is that many

\footnotetext{
32 http://www.ks.no/PageFiles/20007/Rekrutteringsbehov\%20i\%20kommunesektoren\%202012\%20$\% 202022$.pdf?epslanguage $=$ no

33 http://www.ks.no/PageFiles/20007/Rekrutteringsbehov\%20i\%20kommunesektoren\%202012\%20$\% 202022$.pdf?epslanguage $=$ no

34 http://www.ks.no/PageFiles/20007/Rekrutteringsbehov\%20i\%20kommunesektoren\%202012\%20$\% 202022$.pdf?epslanguage $=$ no
} 
students take a longer educational pathway than necessary by attending postgraduate studies instead of being employed. What is important is to establish educational programmes that balances general, broad, and specialised knowledge.

\subsubsection{Recruitment and retention in the educational sector - Need for higher degree of completion in vocational training}

\section{Upper secondary education}

In 2007, 62,932 students attended upper secondary education in Norway, including both specialisation in general studies and vocational training. ${ }^{35}$

When looking at the completion rate of the students who started in upper secondary education in 2007 , a total of $56 \%$ completed within the prescribed time, usually three or four years. ${ }^{36}$ After five years, the completion rate was $69 \%$.

Of those who started at specialisation in general studies in 2007, a total of $74 \%$ completed their education programme within the prescribed time, and after five years the completion rate was 83 percent. ${ }^{37}$ The corresponding percentage for those who started in vocational training in 2007 was 38 and 55 pct respectively.

When looking at those starting in vocational training in 2007, the completion rate is approximately $15 \%$ for the total number of students attending upper secondary education. This is a challenge, in particular when knowing that there will be great need for workers in the area of healthcare, childhood and youth (Meld. St. 20 (2012-2013)).

The fact that the completion rate is relatively low among students attending vocational training, accounts for a prominent challenge to secure an adequate supply of health care workers in the health and care sector. The projections show that the supply of health care professionals with vocational training do not correspond to the population's need for health services and the demand for such educations in the years to come (Meld. St. 13 (2011-2012), Cappelen et al. 2013).

\footnotetext{
35 http://www.ssb.no/vgogjen/

36 https://www.ssb.no/statistikkbanken/selectvarval/saveselections.asp

37 https://www.ssb.no/statistikkbanken/selectvarval/saveselections.asp
} 
Within the health and care area at upper secondary education level, the most relevant education programme is called healthcare, childhood and youth development (vocational training). In 2007, approximately 5,500 students attended the course. $45 \%$ of these students completed within described time. ${ }^{38}$ After five years, the completion rate was $58 \%$.

The healthcare, childhood and youth development programme leads to nine programme areas within the area of healthcare, childhood and youth development. One of the nine education programmes is health care worker.

In 2006, the Health Work training programmes replaced two former vocational education programmes in nursing. Those trained as health workers are initially qualified for employment in a wide range of settings, including hospitals, mental health care, and services for the care and treatment of the elderly (Skåholt et al. 2013). In Norway, as in the rest of the Nordic countries, the health care workers account for the largest group in the health and welfare sector (Meld. St. 13 (2011-2012)).

There are large gender differences when one looks at who attend the healthcare, childhood and youth development course, cf. table 5.6 below. There are also large gender differences when looking at the completion rate.

The government knows too little about why relatively few students complete their training. Some presumed conditions are presented in the white paper Education for Welfare (Meld. St. 13 (2011-2012)):

- Lack of apprenticeship as a part of the vocational training programme leads to drop-out.

- The transition from vocational training programmes to supplementary programme for general university and college admissions certification.

- A decrease in adults attending the training programme. Adults are the most important recruitment group to the health work programme, and account for $80 \%$ of the recruitment base.

- The profession has low status. This has particular significance for the recruitment of men.

38 https://www.ssb.no/statistikkbanken/selectvarval/Define.asp? subjectcode=\&ProductId= \&MainTable $=$ GjennVGOKjonFullf\&nvl=\&PLanguage $=0$ \&nTTmpar=true \&CMSSubjectArea=utdanning\&Kort NavnWeb=vgogjen $\&$ StatVariant $=\&$ checked $=$ true 


\section{Higher education}

As for the expected shortage of professionals with vocational training, the projections also predicts an increased need for health professionals with higher education, albeit to a lesser extent than professionals with vocational training. Overall, the projections show a satisfactory balance between supply and demand for professionals with higher education within health and care at a national level, and the recruitment is relatively good. At the same time, the newest projections show that the supply of nurses may be too low in the future to match the demand (Cappelen et al. 2013).

\begin{tabular}{|c|c|c|c|c|}
\hline \multirow[b]{2}{*}{ Gender } & $\begin{array}{l}\text { Students attending upper } \\
\text { secondary education (spe- } \\
\text { cialization in general studies } \\
\text { and vocational training) in } \\
2007 \text {, completed within the } \\
\text { described time (five years) }\end{array}$ & $\begin{array}{l}\text { Students attending voca- } \\
\text { tional education in } 2007 \text {, } \\
\text { completed within described } \\
\text { time (five years) }\end{array}$ & \multicolumn{2}{|c|}{$\begin{array}{l}\text { Students attending } \\
\text { healthcare, childhood and } \\
\text { youth development (voca- } \\
\text { tional training) in 2007, } \\
\text { completed within described } \\
\text { time (five years) }\end{array}$} \\
\hline & Total & Total & Total & Pct. \\
\hline Men & 32,376 & 17,956 & 510 & 29 \\
\hline Women & 30,556 & 13,087 & 5,019 & 46 \\
\hline
\end{tabular}

Source: Statistics Norway

Table 5.7 shows enrolment and completion in five study programmes by year within the health and care service area from 2009 to 2012. The five study programmes are occupational therapist, physiotherapist, medicine, nursing, and social education.

Enrolment has increased through the period for all five programmes. More or less the same pattern applies to the number of students who has completed their studies in the same period.

\begin{tabular}{|c|c|c|c|c|c|c|c|}
\hline \multirow[t]{2}{*}{ Study } & \multirow[t]{2}{*}{ Gender } & \multicolumn{2}{|c|}{ 2009-2010 } & \multicolumn{2}{|c|}{ 2010-2011 } & \multicolumn{2}{|c|}{ 2011-2012 } \\
\hline & & Total & Pct. & Total & Pct. & Total & Pct. \\
\hline \multirow[t]{2}{*}{ Nursing } & Men & 100 & 32 & 108 & 36 & 113 & 38 \\
\hline & Women & 1,430 & 49 & 1,543 & 52 & 1,570 & 50 \\
\hline \multirow[t]{2}{*}{ Health worker, excl. nursing } & Men & 106 & 31 & 127 & 38 & 172 & 46 \\
\hline & Women & 540 & 41 & 636 & 48 & 662 & 45 \\
\hline \multirow[t]{2}{*}{ Health-, social- and sports science } & Men & 179 & 42 & 214 & 47 & 251 & 48 \\
\hline & Women & 671 & 47 & 716 & 45 & 765 & 47 \\
\hline
\end{tabular}

Source: Statistics Norway.

A lot more women than men attend the five studies described here. The degree of completion, measured in percentages, is overall higher among women than among men. 


\subsubsection{Future needs}

As discussed in the sections above, there is a growing demand for labor in the health and care service sector, and an increasing need for qualified professionals, especially for those with vocational training such as health care workers, and for candidates in nursing and social care at lower level of tertiary education (Cappelen et al. 2013).

At the same time, the health of the elderly is better than before, so even if people live longer, many will be able to meet age under different conditions than previous generations. The elderly of today have higher education, better economy, better housing conditions, and better physics than ever before. They also have a different relationship to technological innovations. This will affect the future organization of the elderly care and the services offered to this group of people.

It is not expected that the demand for professionals will be covered by educating more people within the health and care sector alone. One will also have to make use of the overall care resources, as well as coorganise these resources differently than what is the case today. This will have to be combined with more research and increased knowledge, and adoption of innovative and technological solutions.

Another aspect is that there will likely be a need for a relatively large degree of labour immigration in the future (Meld. St. 13 (2011-2012)). However, the Norwegian government's policy on this topic is not to recruit health professionals actively from countries lacking such expertise themselves (Meld. St. 11 (2011-2012)). A challenge here is that most other countries face the same challenges as Norway. Many people want, however, to work in Norway due to low unemployment and high wages. One of the interviewees exemplified this by showing that Norway receives many Swedish workers despite the fact that Sweden lacks health personnel.

The projected employment of persons with vocational education within nursing and caregiving indicates a clear increase towards 2030. In 2014, the need for employment within nursing and caregiving is around 100 per 1,000 people. In 2030 , this ratio is expected to be approximately 140 per 1,000 .

The projections show that the trend of increasing demand for workers with a tertiary education and upper secondary vocational education will continue towards 2030 . However, the newest projections of demand and supply of labor by education show that the trend in the number of employees with upper secondary education vocational programs has been more moderate during the most recent decade (Cappelen et al. 2013). This is also the case for employees with lower degree tertiary 
education. For those with higher degrees, the increasing trend has not changed.

Different definitions of educational levels in the data basis makes it difficult to project the exact demand and supply for persons with upper secondary education in nursing and care giving (Cappelen et al. 2013). It is, however, estimated that demand will increase by more than $50 \%$ from 2010 to 2030.

Employment by education at a tertiary level with a lower degree also shows a strong increase in demand, including for health personnel. In 2014 , the ratio per 1,000 person is approximately 80 . In 2025 , the ratio is expected to be approximately 125 per 1,000. Employment of persons specialising in other fields of health and social services and in nursing and caregiving is projected to increase from approximately 70 per 1,000 person in 2014 to approximately 80 in 2025. It is expected that some of the demand for nurses will be covered by health care workers (vocational training upper secondary level), but as long as there is an expected mismatch between supply and demand within nursing and care giving at this level as well, it will not produce significant effects.

\subsubsection{Prominent challenges}

It is evident from the sections above that the Norwegian health care sector is under heavily pressure from an aging population and a lack of professional workforce. This section highlights the prominent challenges within the health care sector.

\section{Home nursing and assistance at home}

In Norway, health care workers accounts for 69,000 man-years, which is the largest group in the health and welfare sector (Meld. St. 13 (20112012)). Projections show a understaffing between 10,000 and 18,000 health workers in 2020, and between 35,000 and 52,000 in 2030.

In 2006, the health work education programme replaced two former vocational education programmes in nursing. Health workers are typical employed by the municipalities. The first qualified health care worker graduated in 2009. By the end of 2011, 2,149 health care workers were employed in the municipalities (Skåholt et al. 2013). In 2001, the municipalities employed $80 \%$ of those having either healthcare assistant training, vocational nursing education, or care worker education.

Currently, unskilled workers account for about a third of the manyears in the municipal care services. Due to the expected increase of demand for more workers with relevant vocational training, the number of unskilled workers is expected to increase even more. 
In 2012, there were approximately 271,500 users of nursing and care services in Norway. There were 73,349 users of home nursing (no use of other services), 63,230 users of home help and home nursing, and 42,141 users of home help (no use of other services). There were 3,013 with residents in institutions (long-term stay).

Those aged 80 years or older, use health services such as nursing home and services in the hospital to the greatest extent (Mørk et al. 2013). In 2011, six out of ten persons aged 70 years or older were in contact with a somatic hospital.

There has been an increase of almost $8 \%$ in the number of recipients of long-term care in nursing homes from 2007 to 2012 . 80\% of the recipient group has an extensive need for assistance, and the number in need of extensive assistance has increased with $11 \%$ Nevertheless, the share of the elderly staying at a nursing home has been reduced over the last 30 years.

Four out of five elderly manage on their own, and one out of five receive care services from the municipalities at home (home nursing/assistance at home) or by staying in a care home (Mørk 2013). A relatively small proportion of those receiving some kind of assistance at home has an extensive need for assistance (Mørk et al. 2013). The largest need for extensive assistance is among those aged 90 years or older.

\subsection{Strategies}

\subsubsection{Perception of the challenges}

The conducted interviews suggest a general agreement among the interviewees on status, the challenges ahead, and what needs to be done to meet the challenges. The main explanation for the apparent consensus is the institutionalised Norwegian three-party cooperation, between the state, the employers' organizations, and the employees' organizations.

Despite the consensus, one of the interviews found that the government's implementation capability is too weak. This generates frustration in the sector and the employees' and employers' organisations. It also generates conflicts between the stakeholders involved, which in turn prevents change. It was also emphasised in the interview that the responsible authorities do not gather knowledge at a national level, which affects the coordination of the measures taken negatively. 


\section{Interdisciplinarity and task distribution}

Overall, there is also common agreement that the changes will trigger a need for new work assignments, different skills, and inclusion of other professional groups in the sector.

One of the informants pointed out that it will be important to give managers in the health and care sector information and knowledge about how to make use of the employees' skills and resources in order to achieve skill distribution and interdisciplinarity. Another interviewee pointed out that this also applies to management in the municipalities. Skill distribution and interdisciplinary also requires that the different professions are willing to give up some of their tradition tasks to groups of employees who traditionally have had limited access to perform certain tasks. For example, it can come to a point where nurses can perform traditional medical tasks previously reserved for doctors, and where health workers perform tasks previously reserved for nurses (task delegation).

Such a change will require distribution of skills and responsibilities and formalisation and limitation of roles. It will also require substantive changes in the respective educational programmes and extensive knowledge transfer among employees in the health care sector, and it is important to secure the patients' safety in a systematic way.

In this regard, the Norwegian Directorate of Health points out that there is a desire to ensure that future recruitment to the sector covers other disciplines than what is common today. However, it is unclear how this should be done in practice. It is therefore more conceivable that the traditional disciplines in the sector will be offered to acquire knowledge from other disciplines, such as in technology.

The Directorate also points out that Norway does not have a very strong tradition of thinking efficiency through task distribution and interdisciplinarity, as the country has generally had access to the resources required, both in terms of money and manpower.

\section{Education and competences}

To educate more people to the sector is still a factor that is high on the agenda. Several of the interviewees stressed the need for more formal, informal, and non-formal continuing education of those already employed and a systematic knowledge transfer among both educated and unskilled employees. An element of this is to ensure proper supervision and guidance during the practical part of the education and supervision of new employees. One must have the Life Long Learning-perspective in focus.

In the interview with the Norwegian Directorate of Health, it was pointed out that the national level has failed to establish good arrangements for capacity building among unskilled workers in the health sector. 
It was also pointed out that the potential for such competence building within the health worker subject is vast. Structural, economic, and judicial obstacles were cited as an explanation for this. Examples of projects where various arrangements to promote competences among unskilled workers have been tried as part of the project "Trade Certificate at Work" were pointed out. The pilot projects have yielded positive results without resulting in a continuation or escalation of the projects. An explanation of why the work has stopped is conflicts of interest between the social partners (labour and employer organisations). An important element of the pilot projects has been that they have tried out arrangements that rely more on learning outcome, skills need, and demand than experiencebased trade certifications. Another obstacle to achieving good arrangements for competence enhancement is that counties practice the current legislation differently. There is therefore a need for more detailed national guidelines. Flexibility must be given in the implementation of skills upgrading measures, but not in the interpretation of the requirements.

Several of the interviews pointed out that in order to facilitate formal continuing education, measures that enable employees to combine education, training, and work, both in terms of funding, salary and time, is required. This will also make the profession more attractive.

It was also pointed out that there is a need for more practice positions for nurses in training as part of the education. This is crucial for the attractiveness of the educational programme and the profession, and for the quality of education. Several of the interviewees call for better dialogue between the stakeholders in the sector, the educational institutions, and the government.

One of the interviewees pointed out that municipalities must develop skills and competence plans to get an overview of the skills actually possessed and what they need. They also recommend that the government takes a stronger responsibility in getting an overview of these issues at a national level.

In the interview with the Norwegian Directorate of Health, it was pointed out that the coverage of personnel with higher education is good and the demand for higher education can be said to be covered. However, there may be geographical differences. Many municipalities employ people with higher education to ensure that they have sufficient expertise although there may be more demand for skills at a lower level of education. The extent to which municipalities have an overview of the actual current and future skills and competence needs is a matter of good management. Therefore, the expertise of the leaders is a government priority. 


\section{Part-time jobs and shift work}

There is an extended use of part-time jobs in the health care sector. The municipal sector is the only sector where as many as two-thirds of the employees work part-time. ${ }^{39}$ Several of the interviewees described the lack of full-time jobs in the health and care sector as a challenge. It is a challenge because the consequence is that one needs more staff to fill a vacancy. It is also a challenge for the attractiveness of the profession, both in terms of recruitment and retention, and particularly with regard to recruiting young people. This leads to a high use of unskilled workers, which affects the services` quality and the patient safety.

An explanation of the high degree of part-time jobs is that many women prefer to work part-time. In areas within the health and care sector where most of the men are employed, for example in emergency service, ambulance services, mental health, intensive care, and anaesthesia, the proportion of part-time work is low.

However, both women and men applying to the sector in the future are expected to demand a full-time job. If this is not possible to get, the sector will emerge as unattractive, at least for men. It should also be noted that at present, it is the youngest employees that hold most of the part-times positions.

The gender aspect is therefore seen as particularly important to reduce part-time jobs and raise the status of the profession. Salary is also mentioned as a factor given that men on average earn more than women, which affects the professions' attractiveness.

Another challenging aspect for female-dominated professions is that women have more sickness absence than men. The interviewees emphasised that reducing sickness absence will be important to ensure sufficient future labor supply and to reduce use of unskilled workers.

The interviewees also described the current working time regulations as a challenge because of the introduction of the 37.5-hour workweek in 1986. Many of the positions in the health care sector involve shift work and weekend work and there is strong regulation of the work frequency. However, it is currently difficult to cover the weekend shifts in many health and care institutions and it is challenging to reach agreement on solutions that paves the way for flexibility on how many weekends employees can/should work within a year.

${ }^{39}$ http://www.ks.no/tema/Arbeidsgiver/Kompetanse-og-rekruttering/Heltidskultur/Det-store-heltidsvalget/ 
Again, the gender aspect is mentioned as an explanation of some of the problems. The challenges with filling up the vacancies are bigger in the health care sector than in other similar male-dominated occupations also involving shift work.

\section{Unskilled workers and volunteers}

Although it is a political goal to reduce the number of unskilled workers in the sector, a need for volunteers is also emphasised from a national level. The challenge is to use the unskilled and voluntary capacity in the right way. Volunteering should be a complement, not a substitute for the lack of relevant and skilled labor.

Several of the interviewees said that it is important to put the future need for more volunteers in the care sector in order to relieve the need for assistance among the elderly on the agenda. This refers to both NGOs and the families. At the same time, one of the interviewees expressed concern that many of those who want to volunteer will be women. Some of these women represent labor that is needed in the sector.

\subsubsection{Initiatives - an overview}

In general, the challenges of recruitment and retention of personnel in the Norwegian health and care sector can be addressed at an educational and a workplace level. In table 5.8 below, the Norwegian initiatives are categorised.

Over the past years, the Ministry of Health and Care Services has promoted several central white papers that deal with challenges in the health, social and care service sector, in terms of both access to and demand for labor, changes in skill requirements, changing user groups, and changes in service provision. The Ministry of Education and Research has also promoted a central paper regarding education and supply of adequate and relevant competence to the health and care sector. White papers that can be mentioned are:

- Coping, opportunities, meaning (Mestring, muligheter, mening) (St.meld. nr. 25 (2005-2006)).

- National health care plan (2011-2015) (Nasjonal helse- og omsorgsplan (2011-2015)) (Meld. St. 16 (2010-2011)).

- Future Care (Morgendagens omsorg) (Meld. St. 29 (2012-2013)).

- Education for welfare (Utdanning for velferd)

(Meld. St. 13 (2011-2012)). 


\begin{tabular}{|c|c|c|c|c|}
\hline & \multicolumn{2}{|c|}{ Education } & \multicolumn{2}{|c|}{ Workplace } \\
\hline & Recruitment & Retention & Recruitment & Retention \\
\hline $\begin{array}{l}\text { Examples of } \\
\text { initiatives }\end{array}$ & $\begin{array}{l}\text { Campaigns } \\
\text { Increased intake } \\
\text { New educational } \\
\text { programmes }\end{array}$ & $\begin{array}{l}\text { Mentoring pro- } \\
\text { grammes } \\
\text { Reforms }\end{array}$ & $\begin{array}{l}\text { Campaigns } \\
\text { Strategies }\end{array}$ & $\begin{array}{l}\text { Conditions of } \\
\text { employment } \\
\text { Work/life balance } \\
\text { Working environ- } \\
\text { ment } \\
\text { Continuing educa- } \\
\text { tion and supplemen- } \\
\text { tary training } \\
\text { Management } \\
\text { Talent Management }\end{array}$ \\
\hline Norway & $\begin{array}{l}\text { Increased intake in } \\
\text { all levels of educa- } \\
\text { tion with a focus on } \\
\text { both youth and } \\
\text { adults } \\
\text { Emphasis on aca- } \\
\text { demic breadth }\end{array}$ & $\begin{array}{l}\text { More practical } \\
\text { vocational educa- } \\
\text { tional pathways. } \\
\text { Ensure apprentice- } \\
\text { ships for those } \\
\text { attending vocational } \\
\text { training }\end{array}$ & $\begin{array}{l}\text { Interdisciplinary } \\
\text { recruitment }\end{array}$ & $\begin{array}{l}\text { Facilitate continuing } \\
\text { education/ } \\
\text { supplementary } \\
\text { training and career } \\
\text { opportunities for } \\
\text { health professionals }\end{array}$ \\
\hline
\end{tabular}

It is also implemented various documents that need to be seen in relation to the above mentioned white papers. Here can be mentioned:

- The Care Plan 2015 (a result of the White paper Coping, opportunities, meaning)

- The Care Plan 2020 (a result of the White paper Future Care)

- The Competence Plan 2015 (a result of the Care Plan 2015)

- The Quality Reform in Higher Education.

\subsubsection{Initiatives - in details}

A series of measures to increase the attractiveness and the degree of completion in upper secondary education have been implemented, in particular in vocational training and health and care related educational programmes. There has also been launched various initiatives to increase the recruitment to the health and care sector.

"The Care Plan 2015" (Omsorgsplan 2015) is the action plan of the white paper Coping, opportunities, meaning (St.meld. nr. 25 (20052006)). Overall, the white paper submits the future challenges in the health and care sector.

Care Plan 2015 supports the Norwegian government's five most important long-term goals within the health and care area which are:

"The Competence Plan 2015" is part of the "Care Plan 2015" and is the Norwegian government's overall strategy to promote adequate, 
competent and stabile staffing in the municipal care sector (Meld. St. 16 (2010-2011)). The promoted measures and strategies meet the challenges presented in the white paper National health care plan (20112015) (Meld. St. 16 (2010-2011)). As a result of an aging population where the majority are living longer than before, there will be a need for more services to meet age-related diseases. In addition, there will be an increased demand of services for those with chronic illnesses. ${ }^{40}$

“The Competence Plan 2015" promotes five targets, which are (Meld. St. 13 (2011-2012)):

- Increase workforce in the municipal care services with 12,000 new man-years from 2008-2015.

- Raise the educational level (formal education) in the care service, for example by increasing the proportion of employees having higher education.

- A gross inflow of 4,500 health workers per year; 1,500 youths and 3,000 adults.

- A greater academic breadth in the sector (representation of several professional groups and increased interdisciplinarity).

- Strengthening the guidance, internal training, and continuing education and training.

The measures can be divided into the following purposes:

- Grants to basic education and training, tertiary vocational education (fagskoler), and continuing education for employees in the care sector.

- Other educational provisions for employees in the care sector.

- Grants to service development in the care sector.

- Recruitment initiatives.

The Norwegian Directorate of Health benefits grants under "the Competence Plan 2015", which will be used for recruitment and skill development initiatives. This includes approximately a total of NOK 250 million.

${ }^{40}$ http://www.helsedirektoratet.no/helsepersonell/rekruttering-kompetanse/kompetanseloftet/Sider/ default.aspx 
The distribution of funds to municipalities goes from the Norwegian Directorate of Health via the county departments. Below are some examples of initiatives that may be granted funds: ${ }^{41}$

- "Become a health worker:" The campaign period is 2010 to 2014. The project is a collaboration between The Ministry of Education and Research, and three main representative organizations for Norwegian employers, KS, Virke and Spekter. The Norwegian Directorate of Health finances the project through funds from "The Competence Plan 2015". The project's goal is that more young people and adults shall get formal education in the field of health and care and social subjects, with particular emphasis on the health workers. The project shall also promote more apprenticeship, and emphasizes the quality of education.

- Vocational Competition: Students and apprentices at upper secondary education and training, enrolled at the education programme "Healthcare, childhood and youth development," can get funding to participate in different national and international competitions within health work.

- Recruitment of men: It has been given funding to projects that shall contribute to increased recruitment of men to the health and care sector. Examples of projects are the project "Men in caring professions" at the Telemark University College and the municipality of Trondheim's project "Men in healthcare."

- Education in the special public and private schools offering tertiary vocational education (fagskoler): It is established a grant to educational programmes within the health and social area. To have the opportunity to take continuing education is important to increase the competence, to reduce the turn-over in the sector and to increase the recruitment to the educational programme Healthcare, childhood and youth development in upper secondary education and training.

- Company training: From the funds of "the Competence Plan 2015" it is developed training arrangements for employees in the health care sector, such as "the Dementia care ABC" and "the Elderly Care ABC."

${ }^{41}$ http://www.helsedirektoratet.no/helsepersonell/rekruttering-

kompetanse/kompetanseloftet/rekrutteringstiltak/Sider/default.aspx 
- Leadership Development: On behalf of the Ministry of Health and Care Services there are granted funds for the development of a practical health management training. The purpose is to contribute to strengthening of managers of the municipal health and care services, so they are better prepared to meet future challenges in terms of recruitment and skills development. The Norwegian Directorate of Health promotes this as an essential measure to meet the challenges related to with recruitment and retention.

Overall, "the Competence Plan 2015" has contributed to a stronger emphasis on the importance of competence and recruitment in the sector, and many of the objectives in the strategy are achieved (Tjerbo et al. 2012). ${ }^{42}$ An explanation of why good results have been achieved may be that the Plan has led to a more systematic approach to challenges, both at the state, local government, and business level, which is emphasized to be important by the agency. At the same time, there are signs of stagnation in some areas, such as in the increase of man-years and the recruitment of younger qualified personnel with vocational training (upper secondary level). It also takes place geographic variation. The status of "the Competence Plan" can be summarized as the following, cf. the strategy's five objectives:

- Increase workforce in the municipal care services with 12,000 new man-years from 2008-2015: From 2007 to 2011 there was a growth of about 11,000 man-years in the nursing and care services (Helsedirektoratet 2011). ${ }^{43}$ From 2011 to 2012 there was a total increase of 2,332 man years in the nursing and care sector (Helsedirektoratet 2012). ${ }^{44}$ In 2012 the labor equivalent to 125,486 man years in user-oriented services. The municipals are planning approximately 1,400 new man years in 2013. The planned growth is lower than the growth rate of 1,700 per year which is expected in order to reach the target of 12,000 man years by 2015 . The growth over the last four years is expected to be strong enough to reach the goal of 12,000 new man-years in the strategy period 2008-2015.

\footnotetext{
42 Tjerbo, T. et al. (2012): Bemanning av pleie- og omsorgssektoren: handlingsplan og iverksetting. NIBRrapport 2012:3.

43 Helsedirektoratet (2011): Årsrapport 2011. Omsorgsplan 2015.

${ }^{44}$ Helsedirektoratet (2012): Årsrapport 2012. Omsorgsplan 2015.
} 
- Raise the educational level (formal education) in the care service, for example by increasing the proportion of employees having higher education: Approximately $86 \%$ of the growth in man-years in the period 2007-2012 consisted of personnel with education within health and social education (ibid). The proportion of full-time positions with education within health and social care has increased from $71.4 \%$ in 2007 to $73.8 \%$ in 2012 . The share of man years with higher education has increased from 29.2 to $33.2 \%$ in the same period. In 2012 there were 4,300 health workers working in the sector, representing a strong growth from 2011. At the same time there has been a strong reduction in man years conducted by nursing assistants. The supply of nurses is currently satisfactory. There has also been a growth in the number of social workers. With the current growth, the target of $35 \%$ are considered to be within reach.

- A gross inflow of 4,500 health workers per year: It took place a small increase in applications for enrolment at the education programme Healthcare, childhood and youth development from 2010 to 2011 (Helsedirektoratet 2011). From 2011 to 2012 there was a decrease of 0.5 percentage points (Helsedirektoratet 2012). It is considered to be unrealistic to expect that the number of applicants will increase drastically in the coming years (about $10 \%$ of youth cohorts in upper secondary education). However, there is a potential in getting more people to complete their education/in reducing the dropout rate, and in getting more people to complete a vocational training programme, including apprenticeship, instead of switching to universitypreparatory programmes. From the interview with a representative from the Norwegian Directorate for Health, the recruitment of health workers is pointed out as one of the main challenges in short term.

- A greater academic breadth in the sector: As one of several initiatives to achieve greater academic breadth, the Norwegian Directorate of Health has given Telemark University College the task of developing a training programme in active care (ibid). The term "active care" involves an emphasis on culture, activity and well-being (Helsedirektoratet 2011). By emphasizing active care, it is expected an increased awareness of the need for interdisciplinary.

- Strengthening the guidance, internal training and continuing education and training: Municipalities applying for grants through "the Competence Plan 2015" may get financial support to formal and continuing and supplementary education for their employees (ibid). In 2012 the municipalities were granted NOK 85 million to competence initiatives. In the annual report 2011 it was overall 
considered that the grant scheme had not led to the desired results (Helsedirektoratet 2011). This was explained by drop-out, low progression and challenges for employers to facilitate education. It appears from the annual report 2012, however, that approximately $90 \%$ of the municipalities has applied for funds via the scheme (Helsedirektoratet 2012). The grant scheme for tertiary vocational education (fagskoler) within health and social care has become very important to increase the competence in core subject areas. At the same time the Norwegian Directorate of Health see that many leaders in local government do not know what the tertiary vocational education can offer. The education must therefore be made more widely known.

"Care Plan 2020" is part of the white paper Future Care (Meld. St. 29 (2012-2013)). Some of the main goals that are brought out in the white paper includes:

- To increase the share with higher education

- To mobilise and use the care resources in new ways

- To develop new forms of care through new technology, new scientific methods and new working methods, and through changes in organizational and physical frames

- More research, innovation and development in the municipalities.

"The Care Plan 2020" will be implemented simultaneously with the accomplished "the Care Plan 2015". The latter scheme was discussed earlier. "Care Plan 2020" shall meet the current and the future challenges in the health and care sector:

- Future care: An innovation program towards 2020

- Future care service users - in a resource oriented perspective

- Future care community: A family program, a national volunteering strategy and policy for nonprofit, cooperative-based and private service providers

- Future care services: Professional change and greater emphasis on early intervention, rehabilitation and everyday networking

- Future care facilities: A program for the development and implementation of technology and welfare measures for renovation, construction and development of future nursing homes and care homes. 
The main goals in the White paper Education for Welfare (Meld. St. 13 (2011-2012)) are to strengthen education and research within the health and care area through targeted measures. The White paper promotes three main perspectives, which are:

- The Outside Perspective: It is the society's, the services', and the users' need for assistance that define which content health and social educational programmes shall provide.

- The Interaction Perspective: It is a goal to create better compliance between the demand for competence in the health and welfare services and the education and study programmes' and the research ability to meet the needs.

- The Future Perspective: The measures promoted in the White paper shall lead the way for long-term initiatives.

In the white paper Education for Welfare (Meld. St. 13 (2011-2012)), a key measure was put forward to ensure apprenticeships for those attending vocational training. The Ministry of Education and Research and the main representative organisations for Norwegian employers have therefore established a social contract to ensure this. In 201, a pilot project for the students who did not receive an apprenticeship, and therefore has to finish their training in school, was implemented. Through the pilot project, the training in school will be more similar to the training for those getting an apprenticeship $(2+2$-model $)$, both in terms of the training s content, level of practice, and the training's duration.

Several of the measures in the White paper On the Right Path (Meld. St. 20 (2012-2013)) promote a more practical and practice oriented training in upper secondary education (vocational training). A key measure is the so-called "Switching model" ("Vekslingsmodellen"). Through the measure, there will be a greater exchange between training in the school and at the workplace throughout the training course. This in contrast to the main model for initial vocational training, also called the " $2+2$-model." The model comprising a two-year education in school followed by two years of training at a workplace/in an enterprise.

In addition, initiatives addressing the challenge concerning the low status of vocational training, including the challenge of recruiting men to the health and care sector, can be mentioned. Different kinds of measures to meet the health and care sector's demand for competence and educated personnel with education from higher educational levels have also been implemented. 
The Ministry of Education and Research wants to introduce a new and shared content for the basic educations within the core areas of the health and care field in higher education (Meld. St. 13 (2011-2012)). The goal is to establish broad and flexible educations. This is due to the expectations of a more inter-professional practice in the future. The shared part shall be organised within the different educational areas and educational institutions.

At the same time, there is need for more specialization and expertise. Continuing education has existed for a long time for the basic educations within the areas of health and care. It is granted subsidies to promote continuing education through several national initiatives. As a result of the educational institutions' admission to grant Master's degrees due to "the Quality Reform in Higher Education" ("Kvalitetsreformen"), a significant number of such degrees in the field of health and care have been established. Another focus area in the Reform is increased cooperation between the educational institutions and the working and society life, and institutional freedom in academic, financial/economic and organisational issues to promote relevance and quality of the educational provision.

The Quality Reform in Higher Education was implemented in 2003. Key issues in the reform were implementation of a new degree structure, closer monitoring and follow-up by the students, new examination and evaluation forms, a new financial support scheme, and increased internationalization. 45

To utilize the capacity of the graduates and to secure the retention, it is important that the graduates are given qualified guidance and training in the working life. The Norwegian government will therefor consider the need for different kinds of guidance for the new graduates in the health and care sector in cooperation with the employers.

Economic and financial measures have also been implemented to support municipalities in providing the services they are required.

The employees' and the employers' organizations also contribute in different ways to increasing the recruitment of professionals to the health care sector. The campaign "Become a health worker", as mentioned above, is an example of this. In 2011, the municipal of Oslo made a recruitment film. The purpose was to increase young people's interest in nursing education in general and the elderly in particular. The target

45 http://www.regjeringen.no/nb/dep/kd/tema/hoyere_utdanning/kvalitetsreformen.html?id=1416 
group was young people who would choose an education programme in upper secondary education and training.

In general, all the organizations work specifically with providing information and positive coverage of the health care sector in schools, organizations, and other relevant venues.

As mentioned, the health and care sector is women-dominated, and there are certain challenges related to this. $30 \%$ of the municipalities have implemented measures to recruit more men to women-dominated sectors (Arbeidsgivermonitoren 2013). None of the counties have promoted such measures. The municipal measures have mainly been implemented within the adolescence and education sector and the health and care sector. Only $10 \%$ report that they "to a very large degree" or "to a fairly large extent" have succeeded in increasing the man-ratio in the care sector.

As the Norwegian Directorate of Health pointed out, until now, Norway has had access to the labour force that has been demanded, and unemployment has been low. There are therefore little experience with the current challenges, and there is uncertainty about which challenges will actually materialize. What types of services will be needed? How much can welfare technology contribute? The measures implemented will therefore not be $100 \%$ accurate and Norway acts according to the precautionary principle.

\subsubsection{Concluding remarks}

As evident from the previous sections, the Norwegian authorities are to a very large degree concerned with the future need of health professionals. While the numerical and quantitative perspective is certainly present through for instance traditional recruitment campaigns, it is obvious that a very holistic approach is taken in Norway as well with regards to the future need of health professionals. The holistic approach is especially evident in the Governments large scale strategy within the area of future elderly care - "the Competence Plan 2015." This strategy can be described as the most ambitious and comprehensive plan with respect to the future challenges within the care sector in the Nordic countries. It entails quantitative measures regarding the inflow of health professionals as well as qualitative indicators such as good working conditions, focus on the recruitment of men, reducing sick absenteeism etc. The concrete initiatives taken nationally are, however, scarce in spite of the strategic contemplations being very comprehensive. 


\section{Appendix 5: Sweden}

\subsection{Framework conditions}

\subsubsection{Judicial structure and organisation}

The responsibility for the Swedish health and social care system is divided between the government, the county councils and the municipalities. The Swedish state has the overall responsibility for the health and medical care system and its policies. The Ministry of Health and Social Affairs is responsible for the implementation of health policies set by the government and parliament (The Swedish Disability Federation, 2009).46 Sweden is divided into 20 county councils. In addition to this, Gotland performs the same tasks as a county council although it is officially a municipality. The country is further divided into 290 municipalities (Swedish Association of Local Authorities and Regions). ${ }^{47}$ The Health and Medical Services Act (Hälso- och sjukvårdslagen 1982:763) regulates the division of responsibility between the county councils and the municipalities. The Act is designed to give county councils and municipalities considerable freedom with regard to how their local health and medical services are organized (The Swedish Disability Federation, 2009).48

The above-mentioned Act states that the county councils are responsible for providing inpatient care in hospitals, as well as ambulance transportation if necessary. The county councils are also responsible for providing primary care, which for example includes basic treatment, nursing care and rehabilitation that does not require the specific competencies of hospitals. These areas of responsibility are summarized in the county councils' obligation to offer citizens a care guarantee ${ }^{49}$ - a regulation that was passed In 2010 (Förordning 2010:349 om vårdgaranti). The care guarantee implies that citizens are entitled to: 50

\footnotetext{
46 The Swedish Disability Federation (2009) "En introduktion till hälso- och sjukvårdssystemet i Sverige". ${ }^{47}$ Swedish Association of Local Authorities and Regions, http://www.skl.se/kommuner_och_landsting 48 The Swedish Disability Federation (2009) "En introduktion till hälso- och sjukvårdssystemet i Sverige”. ${ }^{49}$ Hälso- och sjukvårdslagen 1982:763.

50 Förordning 2010:349 om vårdgaranti.
} 
- Availability guarantee: Contact with primary care on the same day as need arises.

- Visit guarantee: A visit to primary care within seven days from the first contact.

- Visit guarantee: A visit to specialized care within 90 days after a referral has been issued.

- Treatment guarantee: Treatment initiation within 90 days after treatment has been assigned.

The purpose of the care guarantee is to reduce the waiting time for patients in the health care. The "waiting list billion," in Swedish "kömiljarden", was introduced as a performance-based compensation to county councils fulfilling the criteria of the care guarantee (The National Board of Health and Welfare, 2013).51 In addition to primary care and inpatient care, the county councils are also responsible for providing dental care to the population according to the Dental Care Act (Tandvårdslag 1985:125). Citizens below the age of 19 are entitled to dental care free of charge (The Ministry of Health and Social Affairs). .52

In combination with the Health and Medical Services Act, the Social Services Act (Socialtjänstlagen 2001:453) defines the activities of the municipalities. The municipalities are responsible for providing home services and, if necessary, housing and care for the elderly. Individuals with physical or mental disabilities are also entitled to adapted housing, as well as support, rehabilitation and accessibility aid. Interaction between the municipalities and the county councils should take place when efforts directed towards elderly and individuals with disabilities are being planned. Cooperation between municipalities and county councils should also take place on issues concerning individuals with a drug or alcohol addiction, as well as in relation to other addictive substances. ${ }^{53}$ The municipality is also responsible for school health services as well as support and different services to individuals who have been discharged from the hospital (The Ministry of Health and Social Affairs). ${ }^{54}$

\footnotetext{
51 The National Board of Health and Welfare (2013), "Vårdgaranti och kömiljard - uppföljning 2012".

52 The Ministry of Health and Social Affairs, http://www.regeringen.se/sb/d/14835

53 Socialtjänstlagen 2001:453.

54 The Ministry of Health and Social Affairs, http://www.regeringen.se/sb/d/14832
} 
As a result of a new law (Lag 2008:962 om valfrihetssystem), a freedom of choice system has been implemented through which the county councils have to allow citizens to choose freely between different primary care providers, including both public and private providers. Municipalities have the possibility to implement a similar system, but are not obliged to do so. The purpose of the freedom of choice system is to provide patients with the opportunity to choose providers based on their preferences, and as an extension of this, increase competition in the health care market. All care providers that fulfill the requirements established by the law have the possibility to establish health care facilities (Swedish Competition Authority, 2011). ${ }^{55}$ The system of compensation is based on the principle that the money follows the patient, regardless of whether the provider is public or private (The Ministry of Health and Social Affairs, 2011). ${ }^{56}$

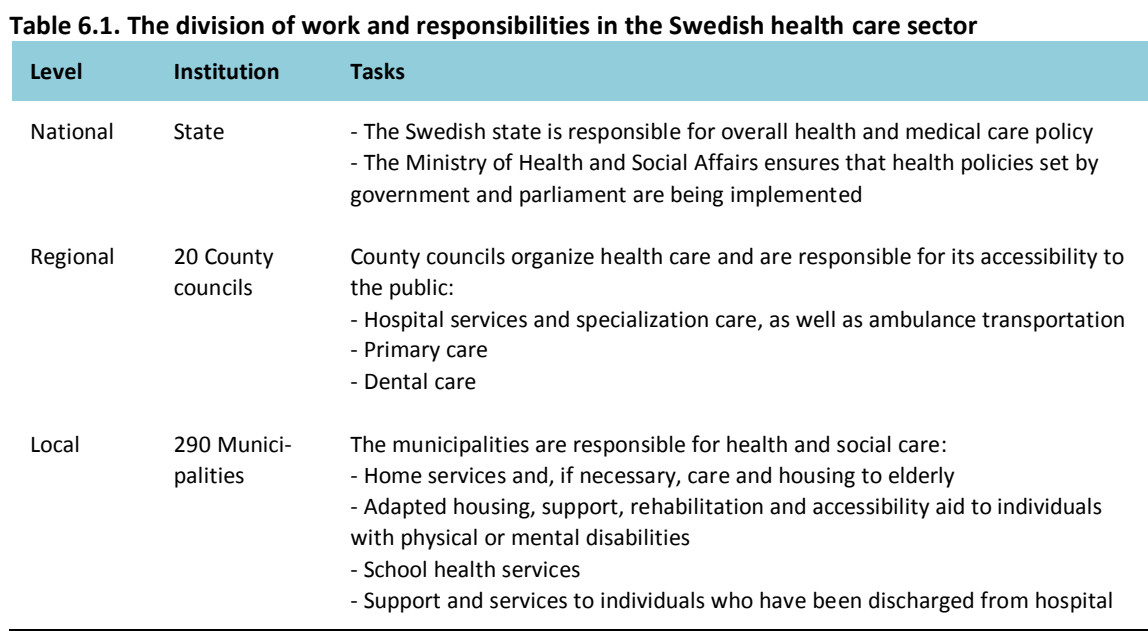

\section{National Board of Health and Welfare}

The National Board of Health and Welfare is a government agency under the Ministry of Health and Social Affairs. Based on health care laws, the Board produces binding regulations as well as recommendations with the aim of increasing quality of health care. In addition to this, the Board produces national guidelines for how to allocate resources to different methods and treatments. Another responsibility of the Board is to perform national evaluations of the Swedish health care (The National

\footnotetext{
55 Swedish Competition Authority (2011), "Lagen om valfrihetssystem - en introduktion".

56 The Ministry of Health and Social Affairs (2011), "Valfrihetssystem ur ett befolknings- och patientperspektiv".
} 
Board of Health and Welfare, 2013). ${ }^{57}$ As an example, the Board conducted evaluations of the previously mentioned care guarantee and the freedom of choice system (The National Board of Health and Welfare). ${ }^{58}$

\subsubsection{Financing}

\section{Expenditures of health and social care in 2011}

Health care expenditures amounted to approximately 337 billion SEK in 2011. In the same year social service costs, excluding municipal health care, totaled 172 billion SEK. Health care and social services combined accounted for $14.1 \%$ of Swedish GDP. Health care, including dental care, constituted $9.5 \%$ of GDP. This represents an increase by 0.2 percentage points since 2003. Social services, excluding municipal health care, represented $4.6 \%$ of GDP in 2012 , which is a decrease of 0.1 percentage points since 2003. In relation to GDP, more resources were allocated to health care than to social services, and to an increasingly degree over time (The National Board of Health and Welfare 2014).59

The county councils financed $72 \%$ of the total health care expenditures of 337 billion. The private sector, in which individual households represent the largest part, accounted for $18 \%$. The municipalities and government financed the remaining 10\% (The National Board of Health and Welfare 2014,60 The Government of Sweden, 2013). ${ }^{61}$

\section{Contributions from the state}

The government provides county councils and municipalities with two different grants: General grants and earmarked grants. The objective of general grants, which are not tied to any particular activity, is to decrease economic inequalities and structural differences between different county councils and municipalities, respectively. General grants to the municipalities are calculated based on the individual municipality's social services concerning individuals and their families, as well as el-

\footnotetext{
57The National Board of Health and Welfare (2013) "Detta gör vi".

${ }^{58}$ The National Board of Health and Welfare, http://www.socialstyrelsen.se/effektivitet/vardirimligtid/ vardgarantin. http://www.socialstyrelsen.se/publikationer2010/2010-2-10

59 The National Board of Health and Welfare (2014) "Tillståndet och utvecklingen inom hälso- och sjukvård och socialtjänst - Lägesrapport 2014"

${ }^{60}$ The National Board of Health and Welfare (2014) "Tillståndet och utvecklingen inom hälso- och sjukvård och socialtjänst - Lägesrapport 2014".

61 The Government of Sweden (2013), “Hälsovård, sjukvård och social omsorg”, Prop. 2013/14:1 Utgiftsområde 9.
} 
derly care. For the county councils, the size of the general grant is based on calculations concerning health care (Statistics Sweden, 2014).62

The earmarked grants have to be used for a predetermined purpose. For the municipalities, such grants are mainly financing education, labor market initiatives and integration, rather than social services. For county councils, however, the government earmarks special grants for pharmaceutical benefits and for increasing the accessibility of health care (The Government of Sweden, 2003;63 The Government of Sweden, 2013).64

\section{Local contributions}

The main source of financing of health care and social services within the county councils and municipalities is through the collection of council and municipal taxes. The county councils and municipalities themselves decide the tax rate and the allocation of the tax income (Nomesko, 2012). ${ }^{65}$ Other funding sources, albeit smaller, are patient fees and revenue from sale of care services (The Government of Sweden, 2014).66

\subsection{Challenges}

\subsubsection{Demographic challenges}

The Swedish population currently amounts to approximately 9.7 million (Statistics Sweden, 2014).67 The population is estimated to reach 10 million in 2017, and by 2060 it is expected to surpass 11.6 million. There are three main reasons behind the rapid population growth: High immigration levels, larger numbers of childbirths and increased average life expectancy. While immigration levels are expected to decline and the number of emigrants is expected to increase in the long term, throughout the forecast period immigration levels are expected to exceed those of emigration.

\footnotetext{
${ }^{62}$ Statistics Sweden (2014), "Kommunalekonomisk utjämning för kommuner, Utjämningsåret 2014, Preliminärt utfall", http://www.scb.se/Statistik/OE/OE0115/2014A01P/

Kommunalekonomisk\%20utjämning\%20för\%20kommuner\%202014,\%20preliminärt\%20utfall.pdf 63 The Government of Sweden (2003), “Allmänna bidrag till kommuner”, Prop. 2003/04:1 Utgiftsområde 25. 64 The Government of Sweden (2013) “Budgetproposition 2014, Utgiftsområde 25, Allmänna bidrag till kommuner", Prop. 2013/14:1.

${ }^{65}$ NOMESKO - Nordisk Medicinalstatistisk Komité, 98:2012, "Hälso- och sjukvårdens finansiering i Norden”. 66 The Government of Sweden (2014), "Hälso- och sjukvård i Sverige",

http://www.regeringen.se/sb/d/14832

${ }^{67}$ Statistics Sweden, June 30 2014, "Befolkningsstatistik", http://www.scb.se/sv_/Hitta-statistik/Statistik-

efter-amne/Befolkning/Befolkningens-sammansattning/Befolkningsstatistik/
} 
Today, $15 \%$ of the population is born abroad and this number is expected to increase to $18 \%$ by 2060 (Statistics Sweden, 2013). .6

Population growth is also explained by a large number of childbirths, exceeding the number of deceased. The large number of births is partly a result of large immigration, but also a result of the fact that children born during the baby boom in the 1990s will reach childbearing age. The number of infants is expected to increase and reach its peak around 2020. Simultaneously, as the number of childbirths increases, so does the average life expectancy. By the beginning of the 1920 s, $40 \%$ of women and $10 \%$ of men reached the age of 90 . Today, the corresponding percentages are $66 \%$ and 60 percent, respectively. Life expectancy at birth in 2012 was 83.5 years for women and 79.9 years for men. By 2060 , this is expected to increase to 88.8 years and 86.7 years for women and men respectively. The death rates in different age groups are expected to decrease, although the forecasts become more uncertain over longer time periods (Statistics Sweden, 2013). ${ }^{69}$

Even though the number of childbirths will grow, the proportion of elderly in relation to the overall population will increase. The share of elderly (65+) is expected to increase from $19.4 \%$ in 2013 to $25.4 \%$ in 2060. This is partly due to higher life expectancy, but also because of the large number of individuals born in the 1940s. The old age dependency ratio $^{70}$ is projected to increase over the time period 2013 to 2060 from 0.33 to 0.49 (Statistics Sweden, 2013). ${ }^{71}$ This larger share of elderly implies an increasing burden on the working age population in the coming years.

\subsubsection{The Swedish work force}

Most of the health care services in Sweden are carried out within the public sector, which is evident in table 6.2 below. The degree to which health care personnel works in the public sector varies between different occupational groups, ranging from $77 \%$ for specialized physicians to $89 \%$ for midwifes.

Table 6.2. Allocation of personnel within the health care in 2011 (pct.)

\footnotetext{
68 Statistics Sweden (2013), “Sveriges framtida befolkning 2013-2060”.

69 ibid.

${ }^{70}$ Here, old age dependency ratio is defined as the total number of individuals aged $65+$ divided by the total number of people in the age span 20-64.

71 ibid.
} 


\begin{tabular}{|c|c|c|c|c|}
\hline \multirow[b]{2}{*}{ Occupational group } & \multicolumn{2}{|c|}{ Median Age } & \multicolumn{2}{|c|}{ Fraction aged $55+$ (pct.) } \\
\hline & 1995 & 2011 & 1995 & 2011 \\
\hline Physicians & 45 & 47 & 15 & 33 \\
\hline Specialized physicians & 47 & 54 & 3 & 11 \\
\hline Nurses & 43 & 46 & 15 & 33 \\
\hline Specialized nurses & 46 & 54 & 19 & 46 \\
\hline Midwifes & 43 & 51 & 12 & 38 \\
\hline Radiology nurses & 45 & 51 & 20 & 38 \\
\hline
\end{tabular}

Source: The National Board of Health and Welfare (2014) "Nationella Planeringsstödet 2014 Tillgång och efterfrågan på vissa personalgrupper inom hälso- och sjukvård samt tandvård".

However, all occupations have experienced a large shift of personnel from the public to the private sector since the mid-1990s. Turning to the gender distribution within the work force, the fraction of women has increased since the mid-1990s among physicians and specialized physicians. In 1995, women constituted 31\% of the specialized physicians, while in 2011 the percentage had increased to $41 \%$. Among physicians, women constituted $45 \%$ in 2011 , compared to $36 \%$ in 1995 . Among younger physicians, women constitute the majority. The situation is different for nurses, specialized nurses, midwifes and radiology nurses, where men constitute less than $15 \%$ of the work force. The most noticeable difference is for midwifes, for which men constitutes less than $1 \%$ of the personnel (The National Board of Health and Welfare, 2014). ${ }^{72}$

Another issue of interest is the age structure of the personnel, as shown in table 6.3. An increase in median age over the years 1995 to 2011 is a prominent feature for all occupational groups presented. The fraction of personnel aged 55 and above has increased immensely. In $1995,19 \%$ of the specialized nurses were aged 55 and above, while the corresponding percentage today is $46 \%$ The National Board of Health and Welfare, 2014).73

\subsubsection{Current supply of health care personnel - unemployment, education and mobility}

During the late $1990 \mathrm{~s}$, unemployment rates peaked at around $1.2 \%$ (1997). Ever since, unemployment rates have decreased continuously. Today, the unemployment rate is low; it has been stable throughout the

72 The National Board of Health and Welfare (2014) "Nationella Planeringsstödet 2014 - Tillgång och efterfrågan på vissa personalgrupper inom hälso- och sjukvård samt tandvård" 73 Ibid. 
2000s at a rate of approximately $0.4 \%$ This pattern implies that for all occupational groups within health care, the demand for personnel is equal to or higher than the supply. A short time period between graduating from medical education to being employed within the health care sector is another sign of high demand of personnel. Table 6.4 presents the percentage of new graduates who found work within one year from graduation from 2009-2011. It shows that more than $90 \%$ in all occupational groups found employment within one year, and this has been relatively stable over the last few years (The National Board of Health and Welfare, 2014). ${ }^{74}$

\begin{tabular}{lccc}
\hline Table 6.4. Share of new graduates who found work in health care within one year from graduation (\%) & $\mathbf{2 0 1 1}$ \\
\hline Occupational group & $\mathbf{2 0 0 9}$ & $\mathbf{2 0 1 0}$ & 94 \\
Physicians & 95 & 92 & 96 \\
Specialized physicians & 97 & 96 & 96 \\
Nurses & 95 & 94 & 96 \\
Specialized nurses & 97 & 97 & 95 \\
Midwifes & 95 & 95 & 90 \\
Radiology nurses & 94 & 94 & \\
\hline
\end{tabular}

Source: The National Board of Health and Welfare (2014) “Nationella Planeringsstödet 2014 Tillgång och efterfrågan på vissa personalgrupper inom hälso- och sjukvård samt tandvård".

Mobility of health care personnel across country borders has increased, both in terms of employment but also in terms of education. In Sweden, the net flow is positive, which indicates that a higher or equal number of health care personnel moves to Sweden to work compared to those moving abroad. The most mobile occupational groups are nurses and, to a noticeably larger degree, physicians. The inflow of physicians from abroad is an important addition to the community of physicians. In $2011,24 \%$ of the physicians had earned their medical degree abroad, and of these, $66 \%$ had been educated in the EU/EES-region (The National Board of Health and Welfare, 2014). ${ }^{75}$

In the fall of 2013, $18 \%$ of the individuals who applied for the Swedish medical program for physicians were admitted (Swedish Council for Higher Education)..$^{76}$ However, the number of Swedish citizens studying to become physicians abroad has increased markedly during the 2000s. In 2001, the number of students studying abroad and receiving

\footnotetext{
74 The National Board of Health and Welfare (2014) “Nationella Planeringsstödet 2014 - Tillgång och efterfrågan på vissa personalgrupper inom hälso- och sjukvård samt tandvård".

$75 \mathrm{ibid}$.

${ }^{76}$ Swedish Council for Higher Education, Antagningsstatistik, http://www.uhr.se
} 
student aid from the Swedish state was 514. Twelve years later, in 2013, the corresponding number was 3,279 students, which is a sixfold increase. Swedish medical students are primarily studying in Poland, Denmark, Rumania and Hungary. However, it is not yet possible to evaluate the effect of Swedish citizens educated abroad on the supply of physicians due to the long duration of the medical education (The National Board of Health and Welfare, 2014). ${ }^{77}$

Based on the findings above of low unemployment, short time from graduation to employment, and mobility patterns, the National Board of Health and Welfare concludes that demand exceeds supply for all occupational groups. The demand is especially high for specialized physicians, specialized nurses and radiology nurses (The National Board of Health and Welfare, 2014). ${ }^{78}$

\begin{tabular}{|c|c|c|c|c|}
\hline \multirow[b]{2}{*}{ Occupational group } & \multicolumn{2}{|c|}{ Sector } & \multicolumn{2}{|c|}{ Gender } \\
\hline & Public & Private & Women & Men \\
\hline Physicians & 81 & 19 & 45 & 55 \\
\hline Specialized physicians & 77 & 23 & 41 & 59 \\
\hline Nurses & 85 & 15 & 89 & 11 \\
\hline Specialized nurses & 84 & 16 & 88 & 12 \\
\hline Midwifes & 89 & 11 & $<99$ & $<1$ \\
\hline Radiology nurses & 86 & 14 & 85 & 15 \\
\hline
\end{tabular}

Source: The National Board of Health and Welfare (2014) "Nationella Planeringsstödet 2014 Tillgång och efterfrågan på vissa personalgrupper inom hälso- och sjukvård samt tandvård" and the National Board of Health and Welfare, statistikdatabas för hälso- och sjukvårdspersonal, http://www.socialstyrelsen.se/statistik/statistikdatabas/halsoochsjukvardspersonal

\subsubsection{Health and social care for the elderly in the future}

As mentioned previously, life expectancy has increased and is expected to continue to rise over the coming years. There is no consistent view in current research on what consequences the increased life expectancy will have on the health of the elderly population in Sweden. A majority of studies have found positive trends among the oldest in terms of mobility and ability to manage daily activities, while other studies points to an increased share of elderly with symptoms of various multiple diseases. Improvements in self-reported ADL (how well you can handle basic

77 The National Board of Health and Welfare (2014) "Nationella Planeringsstödet 2014 - Tillgång och efterfrågan på vissa personalgrupper inom hälso- och sjukvård samt tandvård". 78 ibid. 
functions such as toileting, getting out of bed, etc.) and IADL ability (how well you can perform practical tasks such as cleaning and shopping) may reflect improvements in health. However, it might also be a result of factors such as improved technology in the home, better facilities and increased availability (The Ministry of Health and Social Affairs, 2008). ${ }^{79}$

\section{Health and social care's share of GDP in the future}

The changing demographic situation, i.e. a higher share of elderly with a rising life expectancy, will increase the demand for health care and, consequently, the costs. Another, more important, driver behind growing costs is technological development. Health improvements leading to longer life expectancy increases demand for more effective drugs and technological development, which is assumed to require more resources and financing. Technological development does not only concern medical development; it could also include factors such as adapted housing, increased accessibility in society, and an adapted public transport system.

Overall growth in GDP is expected to be larger than the increased health care costs due to changing demographics. Therefore, the larger share of elderly will not in itself cause health care expenditure's share of GDP to increase. The projection, however, is different when including technological development: Together, the aging population, which will increase the demand for care, and the expected technological development, will increase costs at a higher rate than the overall growth in GDP. The health care's share of GDP is then expected to reach $12 \%$ in 2050, an increase of approximately 2 percentage points compared to 2010 . When excluding technological development, the share will remain unchanged over the period (The Ministry of Health and Social Affairs, 2010). ${ }^{80}$

\section{Staffing needs will increase}

The health care and elderly care sectors together employed approximately 400,000 individuals in 2008, of which $60 \%$ were employed in health care. According to different scenarios, ${ }^{81}$ the total demand for health care and elderly personnel will increase by approximately 46$53 \%$ from 2010 to 2050, slightly less with favorable health trends and

${ }^{79}$ The Ministry of Health and Social Affairs (2008) “I den äldres tjänst, Äldreassistent - ett framtidsyrke”, SOU 2008:126.

${ }^{80}$ The Ministry of Health and Social Affairs (2010) "Den ljusnande framtiden är vård - Delresultat från LEVprojektet", Utredning Yrkeskrav i äldreomsorg.

81 I.e. estimated increased morbidity, deferred morbidity or compressed morbidity.' 
slightly more with unfavorable health development (The Ministry of Health and Social Affairs, 2010). ${ }^{82}$

Over the time period 2010-2050, the demand for personnel is expected to increase as follows:

- $24-28 \%$ in health care

- $\quad 67-76 \%$ in elderly care

- $46-53 \%$ in total

Source: The Ministry of Health and Social Affairs (2010) “Den ljusnande framtiden är vård - Delresultat från LEV-projektet", Utredning Yrkeskrav i äldreomsorg.

As mentioned previously, the demand for physicians is currently higher than the supply (The National Board of Health and Welfare, 2014).83 As a result of a growing population, the number of physicians will have to increase by $14 \%$ by 2050 to keep up with demand. Taking into account not only a growing, but also an ageing population, this figure increases to 26-28\% (The Ministry of Health and Social Affairs, 2010).84

\section{Competition for labor}

As discussed above, the health care work force is ageing and the median age has increased immensely since the mid-1990s (The National Board of Health and Welfare, 2014). ${ }^{85}$ As a result, the number of retirements in the coming years will be large. In combination with an increasing number of elderly who will need more assistance and support in the future, this will cause a significant need for recruitment in health care and social services. At the same time, the student cohorts in high school have decreased, and thus the number of individuals who can possibly enter the future work force has been reduced. Hence, the large number of retirements and a lower number of students will in conjunction result in a markedly increased competition for labor. This will result in a higher pressure on the sector to re-organize health and elderly care in a more

\footnotetext{
82 ibid.

83 The National Board of Health and Welfare (2014) "Nationella Planeringsstödet 2014 - Tillgång och efterfrågan på vissa personalgrupper inom hälso- och sjukvård samt tandvård".

84 The Ministry of Health and Social Affairs (2010) “Den ljusnande framtiden är vård - Delresultat från LEVprojektet". Utredning Yrkeskrav i äldreomsorg.

85 The National Board of Health and Welfare (2014) "Nationella Planeringsstödet 2014 - Tillgång och efter-

frågan på vissa personalgrupper inom hälso- och sjukvård samt tandvård".
} 
innovative and personnel-effective manner (The Ministry of Health and Social Affairs, 2008). 86

The need for labor, and thus the competition for labor, will be especially large in "emigration municipalities." In "emigration municipalities" the net flow of young individuals is negative because the young citizens relocate to other parts of the country to work or study. A forecast shows that if the current gender structure remains, more than $70 \%$ of the economically active women in the northern inland municipalities will have to work in the municipality by 2030 . To meet the increasing labor demand, it is thus important to increase the number of men working within health care and social services (The Ministry of Health and Social Affairs, 2008). ${ }^{87}$

A high competition for labor will presumably increase the demand for labor immigration. However, the level of labor immigration will be limited due to ethical reasons, language issues and because of excessive demand due to a high need for labor in other European countries as well. If labor immigration becomes an essential factor to meet the high demand for labor, skills development and language education will be important in order to maintain the quality within the care sector (The Ministry of Health and Social Affairs, 2008). ${ }^{88}$

\section{Retaining personnel - improved working conditions}

Increased competition for labor, combined with changing preferences among personnel, will put pressure on employers to improve working conditions. In the current work force, the personnel is mainly born in the 1940s and 1950s. Younger generations, and coming generations, are likely to have different expectations of professional life.

Factors affecting the decision of career path and work place will be of a more self-fulfilling kind, such as self-development, career opportunities, stimulating tasks, possible wage development and full time work. At the same time, labor mobility has increased, and the possibilities for changing work place have grown. All this will increase the need to develop attractive work places and improve working conditions (The Ministry of Health and Social Affairs, 2008). ${ }^{89}$

\footnotetext{
${ }^{86}$ The Ministry of Health and Social Affairs (2008) "I den äldres tjänst, Äldreassistent - ett framtidsyrke", SOU 2008:126.

$87 \mathrm{ibid}$.

88 Ibid.

89 Ibid.
} 


\section{Changing educational conditions}

According to projections, the number of students in high school will decrease by over 100,000 in the coming ten years. This represents a quarter of the current number of high school students. As a result, the number of students who choose care training programs in high school will presumably decrease. In order to recruit qualified staff, adult education will thus become more essential (The Ministry of Health and Social Affairs, 2008). ${ }^{90}$

\subsection{Strategies}

\subsubsection{Perception of challenges}

The perception of the future, based on interviews of government officials at the Ministry of Health and Social Affairs, is that Sweden, like several other similar countries, will be in need of a higher number of personnel in health care and social services due to an increasing number of elderly. However, how large the need of personnel will be is uncertain, and it is difficult to make forecasts on this issue.

The characteristics of the labor market will change in the coming years; a lower number of individuals in the working age and a higher number of elderly will put pressure on society. Women tend to enter the workforce later, but they also leave earlier, which is an issue since women constitute the majority of the work force in health care and social services. A report from Blix (2013) ${ }^{91}$ points to a gender difference in the coming generational shift, in which the number of retirements will exceed number of young individuals entering the workforce. For women, the number of retirements is already higher than number of new entrants and this pattern is expected to continue until at least 2025. For men, however, the number of entrants is still higher than number of retirements, and this is not expected to change until 2018.

\footnotetext{
90 Ibid.

${ }^{91}$ Blix, M, Framtidskommissionen, The Government of Sweden (2013) "Framtidens välfärd och den åldrande befolkningen", DS 2013:8.
} 
To meet the changing conditions in society, Blix (2013) emphasizes the importance of a higher number of working hours and a longer working life. Individuals will have to enter the work force earlier and in order to enable this the flow through the education system has to be faster. However, and more importantly, individuals have to work longer and retire at higher ages than today. In addition, the population has to work longer hours each year.

Future challenges concerning personnel in health care and social services can be divided into two parts. First, as discussed above, a larger number of personnel will be needed. However, a larger quantity of personnel will not be enough to meet the future demand. Therefore, and second, a higher quality in terms of efficiency is also needed in order to achieve more with fewer people. The development of welfare technology represents a shift towards more efficient care. However, such a development has to be accompanied by increased competency and educational levels among personnel.

The Swedish Agency for Participation ${ }^{92}$ is working to develop welfare technology within the homes of elderly and within the elderly care. Home care services are resource consuming, and a more effective use of resources is important. As an example, night personnel normally perform visits in the home of elderly during nighttime. A webcam has been developed, which enables personnel to visit the elderly during nighttime without having to be there in person. The webcam allows for cost efficiency, without the social interaction being lost (The Swedish Agency for Participation, 2014). ${ }^{93}$ The greatest challenge for welfare technology is for it to be user-friendly for the elderly patients. In addition, development in welfare technology also creates a need for technical competency among personnel in elderly care.

\footnotetext{
${ }^{92}$ A new Agency that arose when Handisam and Hjälpmedelsinstitutet merged, http://www.mfd.se ${ }^{93}$ The Swedish Agency for Participation, http://www.mfd.se/valfardsteknologi/i-boendet/valfardsteknologii-hemtjansten/
} 
Since the freedom of choice system ${ }^{94}$ within health care and social services was enacted, the opportunities for private actors to work within these sectors have increased (Swedish Agency for Economic and Regional Growth). ${ }^{95} \mathrm{~A}$ growing number of private actors have enlarged the need within the municipalities to follow-up on the care services offered. A larger focus on follow-ups enhances the quality in both the private and public sectors. Increased competency among personnel is important to increase quality, but it is also essential to make use of all existing competences that a person possesses. As an example, the privately run Kavat Vård offers three different "language" senior housing for elderly whose first language is Arabian, Spanish and Persian (Kavat Vård, 2014). ${ }^{96}$ This illustrates how the use of existing competences among personnel can create diversity and increase the quality of care. As mentioned previously, immigration is expected to continue to increase over the coming years (Statistics Sweden, 2013). ${ }^{97}$ As staffing needs will increase and labor immigration becomes a more essential factor to meet this higher demand, language education will be important to maintain the quality of care (The Ministry of Health and Social Affairs, 2008). 98 "Language" senior housing is an example of how competences among labor immigrants could be used to meet the increased demand of elderly care.

Another challenge is to encourage more individuals to choose a career within health care and social services through increasing the attractiveness of both medical education and professions within the care sector. As discussed earlier in the report, preferences among personnel have shifted; younger individuals entering the work force have larger requirements for self-development, career opportunities and possible wage development than older personnel (The Ministry of Health and Social Affairs, 2008). ${ }^{99}$ The new opportunity to become self-employed through a private company might be one career opportunity that could attract more individuals to the sector for health care and social services.

\footnotetext{
${ }^{94}$ Lag 2008:962 om valfrihetssystem.

95 Swedish Agency for Economic and Regional Growth (2009) "Valfrihetssystem - Nya möjligheter för dig som är eller vill bli företagare inom service, vård eller omsorg".

96 Kavat Vård, http://www.kavatvard.se/vara-boenden/

${ }^{97}$ Statistics Sweden (2013), "Sveriges framtida befolkning 2013-2060".

${ }_{98}$ The Ministry of Health and Social Affairs (2008) "I den äldres tjänst, Äldreassistent - ett framtidsyrke”, SOU 2008:126.

99 ibid.
} 


\subsubsection{Initiatives - an overview}

Based on interviews as well as on desk research, the main initiatives that have been promoted in a larger scale have been categorized in table 6.5.

\begin{tabular}{|c|c|c|c|c|}
\hline & \multicolumn{2}{|c|}{ Education } & \multicolumn{2}{|r|}{ Workplace } \\
\hline & Recruitment & Retention & Recruitment & Retention \\
\hline $\begin{array}{l}\text { Examples of } \\
\text { initiatives }\end{array}$ & $\begin{array}{l}\text { Campaigns } \\
\text { Increased intake } \\
\text { New educational } \\
\text { programs }\end{array}$ & $\begin{array}{l}\text { Mentoring } \\
\text { programs } \\
\text { Reforms }\end{array}$ & $\begin{array}{l}\text { Attracting } \\
\text { foreign } \\
\text { health care } \\
\text { personnel } \\
\text { Campaigns }\end{array}$ & $\begin{array}{l}\text { Conditions of employment } \\
\text { Work/life balance } \\
\text { Working environment } \\
\text { Continuing education and } \\
\text { training } \\
\text { Management } \\
\text { Talent Management }\end{array}$ \\
\hline Sweden & $\begin{array}{l}\text { VO-colleges } \\
\text { Increased intakes } \\
\text { to medical educa- } \\
\text { tion } \\
\text { Improved spec- } \\
\text { ialized course } \\
\text { offerings for } \\
\text { physicians }\end{array}$ & & & $\begin{array}{l}\text { VO-colleges } \\
\text { Guidelines for required } \\
\text { competencies in staff } \\
\text { "Kompetensstegen" 2005- } \\
2007 \\
\text { "Omvårdnadslyftet" 2011- } \\
2014 \\
\text { National leadership training } \\
\text { för managers in elderly care } \\
\text { Dementia ABC }\end{array}$ \\
\hline
\end{tabular}

Initiatives within the educational sector have mainly focused on recruiting more students through a higher intake and improved course offerings. In the workplace, the main objective has instead been to retain personnel through several different skills development programs. Thus, to increase the competencies in the work force has been the main strategy in meeting the increasing demand resulting from a growing amount of elderly. The following sections will present the different initiatives in more detail.

\section{Increased intake to medical education}

To meet the growing labor demand, the government has over a longer period of time increased the number of available seats in educations for physicians, nurses and dentists at universities. This enables more young adults to choose the health care as a career path. An initiative that was introduced in 2006 is expected to have increased the intake to education for physicians by $36 \%$ by the completion year of 2015 . In the long run, a higher intake is expected to increase the number of specialized physicians 
as well. The overall intake to the educational programs for physicians, nurses and dentists is expected to increase further, since the Government suggested a continued expansion of these medical programs in the budget proposal for 2014 (The Government of Sweden, 2013).100

The Higher Vocational Education offering includes education in health care and social services. (HVE, 2014). ${ }^{101}$ Through a Governmentled initiative, the intake to all programs within the Higher Vocational Education will increase temporarily. In 2013, there were 1,500 additional enrollments; in 2014 and 2015 the corresponding number is 3,000 each year. The initiative ends in 2016 after a final additional intake of 1,500 students (The Government of Sweden, 2013).102

In $2008,76 \%$ of the personnel at assisted living facilities had some basic education, while the corresponding number in 2013 was $86 \%$. Within home care services, the share with basic education increased from 67 to 75\% over the time period 2009-2012 (The National Board of Health and Welfare, 2014). ${ }^{103}$

\section{Improved course offerings in specialist programs}

In an attempt to increase the number of specialized physicians, the Government has decided to give the National Board of Health and Welfare 30 million SEK per year in 2013 and 2014. The purpose is to improve the range of courses offered in order to attract physicians to the specialist programs (The Government of Sweden, 2013). ${ }^{104}$

A special initiative, the METIS-project, has been directed towards raising the attractiveness of the specialist program in psychiatry, since the extent of physical disorders has increased over the last decade. The project took place in 2007-2012, and the project was granted 35.7 million SEK from the Government. The main focus has been on improving the specialist courses in psychiatry. In 2009, the first METIS-courses were held and in 2012 the course offerings were fully developed. This means that the effect of the METIS-courses on the number of physicians specialized in psychiatry cannot be fully evaluated until 2017. There has

\footnotetext{
100 ibid.

101 Higher Vocational Education, HVE, https://www.yrkeshogskolan.se

102 The Government of Sweden, (2013) "Budgetproposition 2014 Utgiftsområde 16 Utbildning och Universitetsforskning", section 4.6.1, Prop 2013/14:1.

103 The National Board of Health and Welfare (2014) "Tillståndet och utvecklingen inom hälso- och sjukvård och socialtjänst - Lägesrapport 2014".

104 The Government of Sweden (2013) "Hälsovård, sjukvård och social omsorg” Prop 2013/14:1 Utgiftsområde 9 .
} 
been an increase in inflow of physicians to the specialist program in psychiatry, which might indicate a positive effect of this program. However, further evaluation is needed before any conclusions can be drawn (The National Board of Health and Welfare, 2013). ${ }^{105}$

\section{V0-colleges}

VO-colleges (Health- and social care colleges) area cooperation between education providers, unions and employers. There are 17 regional and 70 local VO-colleges. Regional VO-colleges can be started in collaboration between one county council and three municipalities; one regional VO-college can in its turn consist of several local VO-colleges. The purpose of the colleges is twofold. First, it aims to increase the interest and attractiveness of working in the health and social care sector as a means to meet the increasing number of elderly. This is done through offering education to individuals without previous knowledge in health and social care. Second, it also aims to increase the competences in the existing work force through skills development courses targeting personnel (VOcollege, 2014).106

\section{Guidelines for required competence in staff}

To increase the competences in the work force, the National Board of Health and Welfare has produced general guidelines concerning the competences needed among personnel working in social services related to elderly. The guidelines include twelve different areas of importance concerning issues such as age-related diseases, food and nutrition, function preservation care and palliative care. The personnel should also have sufficient knowledge of the Swedish language (The National Board of Health and Welfare, 2011). ${ }^{107}$ In 2012, a guide directly targeting employers was published to inform about the competencies needed among personnel in order to facilitate the employment processes and decisions on skills development of the personnel (The National Board of Health and Welfare, 2012).108

\footnotetext{
105 The National Board of Health and Welfare (2013), "METIS-projektet - uppföljning av SK-kurser i psykiatri 2007-2012 - Slutrapport".

106 Vård- och omsorgscollege (2014) http://www.vo-college.se/om

107 The National Board of Health and Welfare (2011) “Grundläggande kunskaper hos personal som arbetar i socialtjänstens omsorg om äldre" SOSFS 2011:12.

108 The National Board of Health and Welfare (2012) "Rätt kompetens hos personal i verksamheter för personer med funktionsnedsättning - Vägledning för arbetsgivare".
} 


\section{Kompetensstegen}

Carried out over the time period 2005-2007, "Kompetensstegen" was a nation-wide initiative focused on skills development in elderly care within the municipalities. The aim was to support municipalities' long-term development of competencies. 1 billion SEK was allocated to the 287 participating municipalities. The municipalities themselves contributed with an additional 1 billion SEK, mainly due to the reduced working time of the participating personnel. Throughout the whole country, 118,000 employed participated -this constituted $62 \%$ of the work force. Nursing assistants represented the majority of the participants: 101,000 nursing assistants took part of the program. For the remaining participants, 8,000 were occupational therapist, physiotherapists and nurses, 4,000 were managers and 5,000 had different mixed occupations, for example assistance assessors. Skills development most commonly focused on five different areas: Dementia, rehabilitation, ethics, food and nutrition and palliative care (The Government of Sweden, 2007).109

An evaluation of the effect of "Kompetensstegen" and its significance for the elderly was made in 2009. The report focused on the following six different areas, which all werea part of the skills development activities: Assessments, documentation, pharmaceuticals, dental health, prevention of fall injuries and dementia. Positive results were found among personnel receiving education through the "Kompetensstegen" in the areas of assessments, dental health and prevention of fall injuries. Nevertheless, no direct effect on the elderly could be found. In this regard, it is important to note that the evaluation was made shortly after the program ended and the follow-up time was limited. It is possible that a longer follow-up period is needed to find the full effect. Therefore, the results should be interpreted with caution (IMS, 2009). ${ }^{110}$

\footnotetext{
109 The Government of Sweden (2007) "Att lära nära - Stöd till kommuner för verksamhetsnära kompetensutveckling inom omsorg och vård av äldre”, Statens offentliga utredningar, SOU 2007:88. 110 IMS - Institutet för utveckling av Metoder i Socialt arbete - The National Board of Health and Welfare (2009) "Personalutbildning i äldreomsorg - blir den till nytta för de äldre?".
} 


\section{Omvårdnadslyftet}

A new skills development program for personnel working with elderly or individuals with disabilities within the municipalities was initiated in 2011, and will run until 2014. Over this period, the Government will contribute 1 billion SEK in total (Government of Sweden, 2011). ${ }^{111}$ The aim is to improve the competence among occupational groups for which only high school education is needed. The grant can be used of both public and private care providers. The program is performance based; the municipality receives grants based on how many educational points the personnel obtains from either high school, higher vocational education or university. The compensation level depends on which of the three institutions the personnel earn their points from (The National Board of Health and Welfare, 2014) ${ }^{112}$

\section{National leadership training for managers in elderly care}

The Government has decided to contribute 100 million SEK to an education program that aims at increasing the competences among managers. The program is being carried out over the period 2013-2015. The participating managers undergo quarter speed education during two years, obtaining 30 educational points. The program is offered at five different institutions of higher education. Courses concern topics such as the national set of values for elderly, leadership, organization and procurement (The Government of Sweden, 2013). ${ }^{113}$

\section{Dementia ABC}

Swedish Dementia Centre has initiated an online education called Dementia $\mathrm{ABC}$, which is based on the national guidelines on dementia produced by the National Board of Health and Welfare. The Swedish Dementia Centre is financed by the Government, and works on behalf of the National Board of Health and Welfare. Dementia ABC is mainly targeting personnel in health care and social services, but is also available to the public. The aim is for the course participants to learn more about dementia and to see the person behind the disease in order to give the best care possible to each individual (Swedish Dementia Centre, 2014).114

\footnotetext{
111 Government of Sweden (2011), http://www.regeringen.se/sb/d/14403/a/160825

112 The National Board of Health and Welfare (2014) "Frågor och svar om Omvårdnadslyftet 2013-2014".

113 The Government of Sweden (2013) http://www.regeringen.se/sb/d/14932/a/207077

${ }_{114}$ Swedish Dementia Centre (2014), http://www.demenscentrum.se
} 


\subsubsection{Concluding remarks}

A growing share of elderly in need of care and support in the future poses a challenge to the health and social care sectors. The need for personnel will increase, and so will the need for more competent personnel and higher efficiency. At the same time, a higher competition for labor and changing preferences will increase the demands on the workplace.

Several actions have been initiated nation-wide to meet the growing demand from the elderly. Initiatives in the educational sector, however, have, mainly focused on recruitment to the programs. No nation-wide initiatives of retaining students were mentioned during the interviews, or found in additional research. In the workplace the main objective has been to retain the personnel through increased competencies. No initiatives to recruit personnel have been found during research. Thus, the overall focus has been to educate more students in the area of health and social care, and to develop the skills of the existing personnel. A main challenge remains in making occupation in the health and social care sector more attractive. 
Nordic Council of Ministers

Ved Stranden 18

DK-1061 Copenhagen K

www.norden.org

\section{Recruitment and Retention of Health Care Professionals in the Nordic Countries}

The demographic trends and financial constraints in the Nordic countries, and all over Europe, are posing challenges, especially in the health care sectors.

The rising number of elderly with "new" diseases, as well as new technology and inventions, create a growing demand for health care services and health care personnel.

The aim of this report is to establish a clearer picture of the challenges in the future health care sectors in the Nordic countries, especially in terms of lack of health care personnel, and the strategies and initiatives implemented for recruitment and retention of personnel. 